UNIVERSIDADE DE SÃO PAULO

FACULDADE DE FILOSOFIA, LETRAS E CIÊNCIAS HUMANAS

DEPARTAMENTO DE TEORIA LITERÁRIA E LITERATURA COMPARADA

PROGRAMA DE PÓS-GRADUAÇÃO EM

TEORIA LITERÁRIA E LITERATURA COMPARADA

SIDNEI XAVIER DOS SANTOS

A conquista da forma: o amadurecimento do conto no Brasil em

Machado de Assis, Raul Pompeia e Lúcio de Mendonça

São Paulo

2018 
UNIVERSIDADE DE SÃO PAULO

FACULDADE DE FILOSOFIA, LETRAS E CIÊNCIAS HUMANAS

DEPARTAMENTO DE TEORIA LITERÁRIA E LITERATURA COMPARADA

PROGRAMA DE PÓS-GRADUAÇÃO EM

TEORIA LITERÁRIA E LITERATURA COMPARADA

\section{A conquista da forma: o amadurecimento do conto no Brasil em Machado de Assis, Raul Pompeia e Lúcio de Mendonça}

Tese apresentada ao Programa de Pós-Graduação em Teoria Literária e Literatura Comparada do Departamento de Teoria Literária e Literatura Comparada da Faculdade de Filosofia, Letras e Ciências Humanas da Universidade de São Paulo, para a obtenção do título de Doutor em Letras.

Orientador: Prof. Dr. Eduardo Vieira Martins

São Paulo

2018 
Autorizo a reprodução e divulgação total ou parcial deste trabalho, por qualquer meio convencional ou eletrônico, para fins de estudo e pesquisa, desde que citada a fonte.

Catalogação na Publicação

Serviço de Biblioteca e Documentação

Faculdade de Filosofia, Letras e Ciências Humanas da Universidade de São Paulo

S237C

Santos, Sidnei Xavier dos

A conquista da forma: o amadurecimento do conto

no Brasil em Machado de Assis, Raul Pompeia e Lúcio

de Mendonça / Sidnei Xavier dos Santos ; orientador Eduardo Vieira Martins. - São Paulo, 2018.

$120 \mathrm{f}$.

Tese (Doutorado)- Faculdade de Filosofia, Letras e Ciências Humanas da Universidade de São Paulo. Departamento de Teoria Literária e Literatura Comparada. Área de concentração: Teoria Literária e Literatura Comparada.

1. Conto. 2. Século XIX. 3. Teoria do Conto. I. Martins, Eduardo Vieira, orient. II. Título. 
Para meus três filhos: Augusto, Clarice e Beatriz. 
Agradecimentos

Aos professores Marcelo Pen e Regina Pontieri, pela generosidade na qualificação Ao professor Eduardo Vieira Martins, pela orientação sempre tranquila e pontual A Carla, pelo apoio incondicional. 
Resumo: O trabalho pretende analisar o amadurecimento do conto no Brasil a partir da leitura das produções de Machado de Assis, Raul Pompeia e Lúcio de Mendonça publicadas na década de 1880, período que corresponde ao aparecimento de Papéis avulsos (1882) e Histórias sem data (1884), de Machado, do total dos contos de Pompeia em periódicos e da coletânea Esboços e perfis (1889), de Mendonça. Para tanto, far-se-á uma linha evolutiva do conto brasileiro a partir de seu surgimento ainda no período romântico de modo a compreender de que maneira a forma do conto atingiu uma maturidade expressiva e artística na década de 80 , considerando-se o que de fundamental se conquistou ali como fontes para o conto moderno.

Palavras-chave: conto brasileiro; Machado de Assis; Raul Pompeia; Lúcio de Mendonça; século XIX; teoria do conto.

\begin{abstract}
The work intends to analyze the maturation of the short story in Brazil from the reading of the productions of Machado de Assis, Raul Pompeia and Lúcio de Mendonça published in the years 1880, period that corresponds to the appearance of Papéis avulsos (1882) and Histórias sem data (1884), of Machado, of the total short stories of Pompeia in periodicals and the compilation Esboços e perfis (1889), de Mendonça. To do so, an evolutionary line of the Brazilian short story will be carried out from its emergence still in the Romantic period in order to understand how the form of the short story reached an expressive and artistic maturity in the 80 's, considering what of fundamental was conquered there as fountains for the modern short story.
\end{abstract}

Key words: Brazilian short story; Machado de Assis; Raul Pompeia; Lúcio de Mendonça; Nineteenth century; short story theory. 


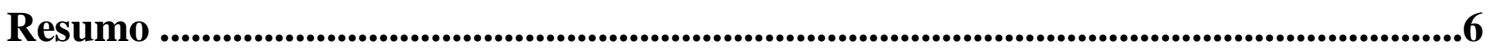

A conquista da forma: 0 amadurecimento do conto no Brasil ................................... 9

1. O conto romântico no Brasil e suas contradições ............................................ 10

2. Dissonâncias ao fim do romantismo ..................................................................... 37

3. Os lances de espelho em Papéis avulsos ............................................................... 58

4. Duas faces de uma moeda: Raul Pompeia e Lúcio de Mendonça ...................... 78

5. A aparência da forma e a essência do conto ..................................................... 103

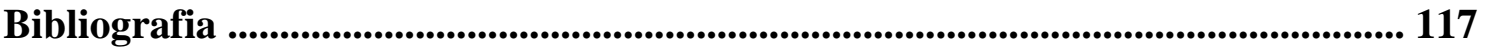


O tamanho não é o que faz mal a este gênero de histórias, é naturalmente a qualidade; mas há sempre uma qualidade nos contos, que os torna superiores aos grandes romances, se uns $e$ outros são mediocres: é serem curtos.

(Machado de Assis, advertência a Várias histórias)

Adstrita a levar em consideração elementos estranhos ao conteúdo artístico - e neste se incluem tanto o sentido estético quanto o ético - corre a história literária o risco de dar apreço excessivo a livros que só valem como documentos, pelas informações que encerram, e a se desviar do seu fim: estudar os sucessos literários, isto é, as obras que por si mesmas ou pela repercussão que tiveram significam alguma coisa.

(Lúcia Miguel Pereira, introdução à Prosa de ficção)

A unidade da obra não é uma entidade simétrica e fechada, mas uma integridade dinâmica que tem seu próprio desenvolvimento; seus elementos não são ligados por um sinal de igualdade e de adição, mas por um sinal dinâmico de correlação e de integração.

A forma da obra literária deve ser sentida como uma forma dinâmica.

(J. Tynianov, "A noção de construção") 
A CONQUISTA DA FORMA:

O AMADURECIMENTO DO CONTO NO BRASIL

EM MACHADO DE ASSIS, RAUL POMPEIA E LÚCIO DE MENDONÇA 


\section{O CONTO ROMÂNTICO NO BRASIL E AS CONTRADIÇÕES DA FORMA}

Em 6 de janeiro de 1894, A Semana, hebdomadário carioca dirigido por Valentim Magalhães, que reunia boa parte da intelectualidade carioca de então e se arvorava como uma revista que pretendia ser fiel aos acontecimentos da semana ${ }^{1}$, publicou em uma de suas colunas uma enquete denominada "Plebiscito Litterario", na qual lançava a vários de seus colaboradores a pergunta "Quaes são os seis melhores contos escriptos por literatos brasileiros?”. Na pergunta não havia nenhuma especificação em relação a período a ser observado, delimitando a data em que os contos deveriam ser considerados, ou modelo de conto, supondo que se pudesse fazer uma distinção entre contos românticos e realistas, nem mesmo uma designação mais precisa do gênero em questão, o que levaria um dos colaboradores, Garcia Redondo, por exemplo, a desconsiderar o texto "Rapsódias", de Coelho Neto, qualificado pelo votante "mais no gênero de quadros do que de contos" ${ }^{2}$. Era também possível, como expressa a chamada para o Plebiscito, publicada na revista em 23 de setembro do ano anterior, votar em contos tanto publicados em volumes quanto em jornais e revistas "da Capital Federal ou dos Estados"3. Ou seja, o critério era bem aberto, ficando ao votante a decisão do que incluir ou não como conto, como mostra a explicação de Garcia Redondo. Tal enquete, na sua pretensa autoridade, uma vez que intenta estabelecer a seu público leitor um cânone de qualidade para o conto, talvez nos possa ser útil para entendermos de que maneira, isso já em 1894!, os intelectuais brasileiros observavam criticamente o gênero, ou, suposição apenas em função dos resultados da enquete, de que modo podemos alocar a recepção crítica do conto brasileiro poucos anos após a publicação de pelo menos duas das coletâneas mais significativas de Machado de Assis, Papéis avulsos (1882) e Histórias sem data (1884), de todo conjunto de contos de Raul Pompeia nos jornais cariocas e da coletânea Esboços e perfis (1889), de Lúcio de Mendonça, compreendendo esses três autores como fundamentais para o amadurecimento do gênero em terras nacionais.

A mesma revista havia divulgado uma enquete semelhante no mês de agosto, tendo como objeto o romance, e publicado seu resultado na edição de 23 de setembro de

\footnotetext{
${ }^{1}$ Cf. RAMOS, Ana Flávia Cernic. "Imprensa e literatura: o caso Castro Malta na configuração do jornalismo carioca em finais do século XIX”. VI Simpósio Nacional de História Cultural: Escritas da História: Ver-Sentir - Narrar. Teresina: Universidade Federal do Piauí, s.d.

${ }^{2}$ A Semana, 06/01/1894.

${ }^{3}$ A Semana, 23/09/1893.
} 
93, quando lançou outra sobre o conto. Há de se notar entre as duas uma diferença significativa em relação ao número de votantes, tendo a primeira recebido 293 cédulas de votação, que deram a Os Maias, de Eça de Queiroz, o primeiro lugar entre os melhores romances escritos em língua portuguesa, ficando O primo Basílio, do mesmo autor, em segundo, e Memórias póstumas de Brás Cubas, de Machado de Assis, em terceiro. Quanto aos contos, o número de votantes, embora não declarado pela revista, certamente mostrouse bem menor, uma vez que o mais votado, "No Horto", de Coelho Neto, recebera "a maioria de três votos" ${ }^{4}$, enquanto o romance de Eça havia recebido 94 votos. O contraste provavelmente nos mostre algo para que Machado de Assis já havia chamado atenção muitos anos antes em seu artigo "Instinto de nacionalidade" (1873), no qual destaca a pouca atenção dada ao gênero pelos escritores e, também, pelo público ${ }^{5}$, o que a enquete acaba por corroborar com seus resultados e pela conclusão publicada pelos editores:

Do que observamos e pode também observar o leitor, os contistas mais lidos são Coelho Neto, Machado de Assis e Valentim Magalhães - o que é natural, pois são eles os que mais numerosa e assiduamente têm cultivado esse difícil gênero. ${ }^{6}$

À parte a pouca afluência de votos para a enquete, cabe observar outro aspecto importante, que é entender quais contos vinham sendo lidos no Brasil daquele momento ou, como pede a enquete, quais vinham sendo julgados como os melhores escritos em língua portuguesa. Se de fato os três autores mais citados são Coelho Neto, Machado de Assis e Valentim Magalhães, cabe destacar que do primeiro são citados 20 títulos, enquanto de Machado são lembrados 11 títulos e de Valentim Magalhães, nove. Um autor hoje completamente desconhecido, como Emmanuel Karneiro (sic) tem três contos votados pelos leitores, mesmo número citado de contos de Lúcio de Mendonça. Raul Pompeia não tem nenhum conto citado. Dentre outros nomes que hoje não costumam ser lembrados por sua contribuição ao gênero estão alguns bastante conhecidos nossos, como os dos românticos Álvares de Azevedo, com "Noite na taverna", Fagundes Varela, com "As ruínas da glória" e Casimiro de Abreu, com “A virgem loura". Provavelmente, como boa parte das enquetes jornalísticas, feitas no afã da divulgação, sem critérios muito detalhados, o resultado reflete uma situação de momento, em que evidentemente os autores mais lembrados são os que mais publicam, como afirmam os editores. No entanto, o conjunto também vai nos mostrar que, apesar da predominância do conto regionalista,

\footnotetext{
${ }^{4}$ A Semana, 06/01/1894.

${ }^{5}$ O Novo Mundo. Nova York, 24 de março de 1873.

${ }^{6}$ A Semana, 06/01/1894.
} 
com nomes como os de Coelho Neto, Valentim Magalhães, Inglês de Souza e Bernardo Guimarães, havia ainda uma ressonância romântica forte, não apenas pelos autores (que eram essencialmente poetas) românticos citados, mas de contos como "Miss Dollar" e "A parasita azul", de Machado de Assis, "O último concerto", de Luís Guimarães Jr., "Lembra-te de mim”, de José de Alencar, ou "Lien-Hôa”, de um esquecido Luiz Rosa, todos eles de extração fundamentalmente romântica. Talvez seja essa ressonância que nos caiba então discutir, procurando compreender o que alguns contos românticos possam ter em suas especificidades e contradições que tenham permitido sua permanência na memória de leitores já tão afastados do romantismo.

Ao retomarmos a história do conto no Brasil, vemos que há uma certa concordância em estabelecer que o gênero foi introduzido no país por volta de 1840 , basicamente em torno de periódicos que passaram a publicar seções literárias ao menos uma vez por semana, preocupando-se inicialmente com traduções de autores estrangeiros ${ }^{7}$, mas posteriormente publicando também autores nacionais. A essa gênese do conto literário no Brasil se dá importância somente histórica, pois não parece haver um autor de originalidade e destaque que possa ser recuperado e incluído no cânone do gênero no país. Nomes como Justiniano José da Rocha, Pereira da Silva, Josino Nascimento Silva e outros, quase todos hoje esquecidos, possuem pouca representatividade ao considerarmos seus escritos através de um olhar estético. Embora saibamos que nomes como Washington Irving, Prosper Merimée, Charles Nodier eram publicados nos jornais, em traduções às vezes dos próprios autores brasileiros citados acima, e que, portanto, fizeram uma espécie de educação literária desses intelectuais, pouco se encontra em suas obras, em termos estéticos, do que encontramos nos originais estrangeiros $^{8}$. Em relação ao conto, o aprendizado dos homens de letras no Brasil parece ter demorado a fazer efeito, em termos de domínio da forma e do estilo, dando-nos uma produção em geral mais aparentada à novela ou a um pequeno romance, derramada em sentimentalismo e profusa em figuras de hipérbole e antíteses ${ }^{9}$.

O mais importante nesse sentido seja talvez reforçar o que nos afirma Lima Sobrinho, que "a história literária do Brasil ganharia pelo menos 10 anos, se se escrevesse

\footnotetext{
${ }^{7}$ Para uma visão mais completa do que afirmo ver SOBRINHO, Barbosa Lima (org.). Os precursores do conto no Brasil. Rio de Janeiro: Civilização Brasileira, 1960, col. Panorama do conto brasileiro, v.1.

${ }^{8}$ Idem, p.13.

${ }^{9}$ Ibidem, p.23.
} 
tomando para referência os jornais e não os livros". ${ }^{10}$ Certamente, o estudo a partir desse ponto de vista incrementaria nosso acervo, principalmente em relação às narrativas curtas, muitas delas até hoje ignoradas nos jornais do século XIX.

A afirmação nos chama atenção para o fato de que o jornal foi o canal primeiro e mais eficiente de divulgação da ficção no Brasil, seja ela na forma de romance ou de conto. A verdade é que a atuação desses homens, em sua maioria jornalistas bastante informados do que ocorria em termos literários na França e Inglaterra, construiu uma base para as gerações posteriores, e, se suas obras não merecem hoje o louvor da originalidade, talvez mereçam, uma ou outra, alguma consideração em relação ao que eventualmente tentaram fomentar de novo, apesar de suas tão propaladas contradições e falhas. É de certo interesse, nesse sentido, o mapeamento que Lima Sobrinho faz dessa produção precoce, dividindo-a em três fases, reservando o decênio 1830-40 para os precursores, o de 40-50 para a afirmação do romantismo e os de 50-60 para o apogeu da escola romântica na prosa $^{11}$, dando-nos uma ideia de amadurecimento gradativo, embora lento, de uma determinada forma literária. Um aspecto mais evidente do momento histórico em que o conto se introduz no Brasil, ou seja, na primeira fase de implantação do romantismo, é o seu caráter de diletantismo, que nem mesmo Machado de Assis negará de todo, já no final do século XIX ${ }^{12}$, e que Sobrinho demonstra de forma mais cabal e pragmática, dando ares de importância menor à confecção dos contos em seus primórdios aqui:

Antes de tudo, precisamos observar que os precursores do conto não eram, a rigor, vocações espontâneas. A primeira impressão que eles nos dão é a de jornalistas, habituados com os modelos europeus, e interessados em transportar para o Brasil um tipo de ficção, que estava sendo um dos fatores do êxito dos periódicos literários ou políticos, que circulavam no Velho Mundo. Essa razão, porém, é antes jornalística do que propriamente literária. Que se não tratava de vocações espontâneas ou irredutíveis para a ficção, prova-o o fato de que não persistiram no cultivo do gênero. ${ }^{13}$

Um segundo aspecto para a suposta precariedade do conto romântico reside na sua própria fatura, que pareceu a alguns críticos como verborrágica e pouco apropriada para o gênero, que exige fundamentalmente a contenção e a síntese. A esse fator dão importância capital não só Lima Sobrinho, mas também Edgard Cavalheiro. O primeiro relaciona o estilo dos contistas românticos aos fundamentos ideológicos dessa estética,

\footnotetext{
${ }^{10}$ Ibidem, p. 15 .

${ }^{11}$ SOBRINHO, p.21.

12 Ver por exemplo sua advertência ao volume de Várias histórias, de 1896, em que, citando Diderot, Machado chama os contos de "modo de passar o tempo". À parte a ironia tipicamente machadiana, ela certamente traduz um lugar comum de então sobre a natureza e recepção do conto no Brasil.

${ }^{13}$ SOBRINHO, p.22.
} 
tais como a liberdade na expressão e a valorização do sentimento pessoal, traduzidas, portanto, por uma linguagem arrebatada, sem limites, visceral e pouco racional:

O que de fato caracteriza a novela romântica é a exaltação do sentimento, que passa a ser a razão única da própria existência, capaz, por si mesma, de justificar todas as atitudes, por mais absurdas que pareçam ao racionalismo e ao espírito crítico de nosso tempo. O que hoje consideramos ridículo, ganhava foros de sublime no apogeu do romantismo. À exaltação dos sentimentos e à apologia das paixões conviria um estilo declamatório, com o fogo-fátuo das antíteses, o exagero das hipérboles, a riqueza ou a quantidade de imagens, que pudessem valorizar os sacrifícios, as renúncias e os sofrimentos do texto. ${ }^{14}$

Edgard Cavalheiro, em Evolução do conto brasileiro (1954), apesar de salvar do limbo apenas dois autores românticos, Álvares de Azevedo e sua Noite na taverna, com suas influências de Hoffmann e Byron, e Bernardo Guimarães, com seus contos regionalistas, vai lamentar que autores como José de Alencar e Joaquim Manuel de Macedo, prolíficos no romance, não tivessem se aventurado no conto, atribuindo a razão às características do romantismo:

Escritores fecundos, com dezenas de obras publicadas, mas com raríssimas incursões pelos domínios do conto. A explicação para essa abstinência num gênero tão acessível reside no fato de que todos esses escritores estavam, antes de mais nada, imbuídos do espírito romântico. E o romantismo - pelo menos o romantismo brasileiro, herdeiro direto de Byron, Chateaubriand ou Victor Hugo, foi essencialmente palavroso, foi principalmente um movimento poético. Sobrepor o sentimento à razão, o entusiasmo ao raciocínio, o subjetivismo ao objetivismo, constituem alguns traços mais salientes de um espírito romântico. Acrescente-se, a isso, a capacidade para as generalizações imaginosas em prejuízo do senso crítico, com total ausência de análise. Nunca, em literatura alguma, se empregou tantas reticências e pontos de exclamação. E o conto, pela síntese que exige, pelo poder de concentração que requer, não era, evidentemente, um gênero propício aos românticos. ${ }^{15}$

Alceu Amoroso Lima reforça o aspecto sentimental do romantismo como avesso à confecção contida do conto, chegando a afirmar que o romance receberia bem essa característica, mas que o conto, que ainda mal nascera no país, definhou em virtude desse derramamento. Diz o crítico:

A peculiaridade natural do sentimentalismo romântico como que esbarrava diante das exigências intrínsecas do gênero, contrárias a essas expansões fantasistas e ao estilo derramado. Talvez seja esta a explicação da extrema pobreza do conto romântico. ${ }^{16}$

\footnotetext{
${ }^{14}$ Idem, p. 23.

${ }^{15}$ CAVALHEIRO, Edgard. Evolução do conto brasileiro. Rio de Janeiro: MEC, 1954, p.24.

${ }^{16}$ LIMA, Alceu Amoroso. “A evolução do conto no Brasil”. In.: Curso de conto. Rio de Janeiro: Academia Brasileira de Letras, 1958, p.17.
} 
No entanto, assim como Cavalheiro, Alceu Amoroso Lima salva de sua pena capital o romântico Álvares de Azevedo e a Noite na taverna, destacando a influência de Hoffmann e Heine e elencando uma linha de imitadores do poeta brasileiro que fariam contos dentro do mesmo estilo fantástico e misterioso, como Fagundes Varela, com "Ruínas da glória", e Franklin Távora, com "Trindade maldita".

Considerando os aspectos depreciativos que a crítica reserva ao romantismo, em especial o que esses mesmos aspectos significam para a elaboração de contos no período romântico, pode-se inferir que a produção de narrativas curtas de raiz romântica estaria por si comprometida em função de uma inadequação entre forma e conteúdo, o que as palavras dos críticos sublinham. Pode-se fazer aqui um paralelo com aquilo que Erich Auerbach dispõe sobre o início da novela na Europa, em especial na Itália e na França. Ao localizá-lo no instante em que ocorre a percepção da "tensão entre a tradição cavaleiresca e eclesiástica e a existência citadina e individual" ${ }^{17}$, momento histórico de profundas mudanças na mentalidade do homem europeu, já ao final da Idade Média, a literatura, segundo o crítico alemão, "carecia de uma atitude face ao mundo empírico"18. Isso significa dizer que, lançado ao mundo das coisas materiais, sobre as quais não refletia durante o período medieval, o homem se viu sem o preparo necessário para a expressão dessa nova configuração. Devolvido ao realismo que adormecera com a queda do Império Romano, os literatos necessitam de uma nova forma que lhes dê as condições para a configuração dessa nova realidade. Essa nova expressão só seria possível com o advento da novela, de base fundamentalmente realista, que daria as condições técnicas necessárias para a expressão da vida.

Para escrever uma novela[...] era preciso executar a seguinte tarefa: diante da variedade infinita dos acontecimentos sensíveis devia-se fixar um acontecimento determinado e elaborá-lo, juntamente com seus condicionantes, de tal modo que expusesse de maneira representativa a variedade infinita.[...] O mundo, tanto tempo abandonado, estava apartado do homem, e este, da mesma forma, dele se afastara; e, quando o homem novamente se voltou para o mundo, teve de fazer um esforço gigantesco para dominá-lo. Toda a sua estrutura se lhe tornara estranha; o homem não enxergava mais a quantidade infinita dos acontecimentos que se interpenetram e que juntos resultam num todo (a causalidade), mas apenas fatos isolados um aqui, outro acolá - e, se conseguia juntar dois ou três, extraindo-lhes talvez uma doutrina moral, prostrava-se exausto e renunciava a apreender o todo. ${ }^{19}$

\footnotetext{
17 AUERBACH, Erich. A novela no início do Renascimento: Itália e França. Trad. Tercio Redondo. São Paulo: Cosac Naify, 2013, p.65.

${ }^{18}$ Idem, p. 65.

${ }^{19}$ Ibidem.
} 
Auerbach visa expor que diante de uma realidade histórica e social nova, talvez até mesmo psíquica, os meios de expressão necessitam encontrar novos mecanismos para traduzirem esse novo espírito de época. Os exempla e fabliaux a que alude já não serviam mais a essa função. Somente a novela, e dá grande destaque ao modo como Boccaccio a concebe em seu Decameron, com sua virtuosidade realista e flexibilidade moral, é que pode atingir esse alvo. Reparemos como a relação entre a forma e aquilo que ela deve expressar estão intimamente ligadas. Sem essa cumplicidade entre uma e outra, algo se torna inapto e frouxo, e a matéria de uma não cumpre a expectativa de outra, ficando ambas órfãs, saudosas de uma fraternidade que não conheceram.

A matéria romântica, com sua essência calcada no sentimento e na liberdade desse sentir, avessa a regras e limitações, refratária a uma razão fria e lógica, abraçada ao seu subjetivismo, não teria como ser domesticada pela contenção objetiva do conto, o seu mecanismo geométrico de histórias. Parece haver entre esses dois elementos um distanciamento incontornável. A explicação parece plausível se a tomarmos como única possível para a inaptidão dos autores românticos para o conto, como tanto repetem os críticos. Que seja fato, a escassíssima produção de qualidade no gênero desta época não leva necessariamente a crer que o problema esteja no derramamento verbo-lacrimoso dos escritores e na sua tendência de dar livre trânsito às dores da alma, frente ao comedimento desejado das orações e períodos do conto. Talvez possamos investigar a hipótese de que outros elementos possam estar presentes no conto romântico que nos auxilie a entender o que escritores como Machado de Assis, Raul Pompeia ou Lúcio de Mendonça deixaram para trás para elaborarem um conto de melhor qualidade e eficácia estética que até então se escrevera. Para isso será necessário analisar alguns contos românticos, talvez alguns ainda lembrados em 1894, na enquete de A Semana, e outros certamente já esquecidos, mas que possam nos oferecer alguma pista sobre o modo romântico de escrever contos.

Vimos que uma das principais críticas em relação à má qualidade dos contos românticos envolve a sua extensão, compreendida essa não somente em termos quantitativos, pelo número de páginas, mas também qualitativos, no sentido de eles dizerem mais do que deveria ser dito ${ }^{20}$, prolongando-se em frases e imagens, acumulando

\footnotetext{
${ }^{20}$ Auerbach também aborda a questão da extensão na novela renascentista, criticando os excessos inúteis. Alguns autores até conseguem elaborar uma "criação vívida" em suas novelas, mas "tão logo buscam compor um processo mais amplo, falham e se afogam no assunto". Para não citar o trecho todo, em que o crítico analisa alguns enredos novelescos, pinço algumas frases: "em seguida os destinos de Fazio são narrados longamente", "proliferam cenas palacianas e de caça, pequenas intrigas e o cerimonial", "fruímos o detalhe ociosamente, mas antes é preciso esclarecer racionalmente o motivo", "nela, as histórias prévia e
} 
detalhes não funcionais, em virtude, segundo os críticos, de um excesso de sentimentalismo e subjetivismo que impregnam as histórias sob todos os seus aspectos, faltando-lhes uma razão ordenadora. Para entendermos o que isso significa na prática e talvez chegarmos a conclusões parecidas, mas com um elemento um pouco mais abrangente de análise, utilizaremos parte da tipologia sobre o conto apresentada por Norman Friedman em seu estudo "O que faz um conto ser curto?"21, que também poderia ser traduzido mais livremente por "O que faz uma história curta ser curta?"22. Parto da hipótese de uma dificuldade dos escritores românticos em alcançarem a essência do gênero conto, fundamentalmente ligada à síntese, em virtude de uma necessidade imperiosa que tinham de estabelecer a verossimilhança. Tal necessidade advinha de uma observação racional, porém falha, das contradições estruturais de suas histórias, solucionadas de forma equívoca, não porque vistas de maneira subjetiva, mas porque abordadas de modo superficial. O grande paradoxo talvez seja o de dizer que os escritores românticos precisavam justificar o derramamento sentimental e subjetivo através de uma cadeia lógica de causas e consequências, com tudo explicado em detalhes, para que as atitudes extremadas de personagens pudessem ser minimamente aceitas. Nesse sentido, talvez não seja estranho considerar que a invenção do conto policial moderno e de raciocínio se atribua a um autor romântico como Edgar Allan Poe, com o seu "The murders in the rue Morgue", de $1841^{23}$. No entanto, o que para o conto policial funciona como solução, para o sentimental adquire uma feição descompassada, desequilibrando o efeito principal de uma história, tornando-a esteticamente improfícua.

Vejamos como a questão se dá em um conto romântico ainda da fase dos precursores no Brasil, momento pouco observado pela crítica em função de uma quase unânime aceitação de que esses escritores nada contribuíram esteticamente para o gênero conto ou mesmo para a prosa brasileira. Vários nomes já foram citados anteriormente, os

\footnotetext{
intermediária, o cortejo frustrado e a desgraça de Catalina podem ocupar todo o espaço que o assunto demandar", "socorre-se de uma acumulação pobre, força as situações até o intolerável, para servir lascívia a rodo", "para expor a reviravolta anímica vale-se de uma aparição e preenche três quartos da novela com astúcia militar e suas consequências". AUERBACH, op. cit., p.83. Tenha-se em conta que as falhas apontadas nas novelas têm impacto direto sobre a profundidade psicológica das personagens e sobre o efeito possível dos enredos.

${ }^{21}$ FRIEDMAN, Norman. "O que faz um conto ser curto?". Trad. Marta Cavalcante de Barrros. Revista USP, São Paulo, n.63, p.219-230, setembro/novembro 2004.

${ }^{22}$ O título original é "What makes a short story short?", publicado em 1976.

${ }^{23}$ Julio Cortázar cita esse conto em seu famoso estudo sobre Edgar Allan Poe, afirmando que nele é "onde surge pela primeira vez o conto analítico, de fria e objetiva indagação racional", em que o detetive Dupin, alter-ego de Poe, "paira nas alturas do raciocínio puro". CORTÁZAR, Julio. "Poe: o poeta, o narrador e o crítico". In.: Valise de cronópio. Trad. Davi Arrigucci Jr. e João Alexandre Barbosa. São Paulo: Perspectiva, 1993, p.127.
} 
quais ficarão apenas mencionados. Por uma questão mais próxima da linha de argumentação que pretendemos, a escolha recaiu sobre um conto relativamente curto, considerando o padrão da época, que nos servirá melhor para observarmos suas questões estruturais $^{24}$. A ideia é demonstrar que, mesmo quando a síntese foi buscada, ela não consegue atingir uma eficácia devido exatamente a problemas nessa estrutura, o que significará dizer, posteriormente, que a questão da síntese não tem necessariamente a ver com tamanho ou quantidade de palavras ${ }^{25}$. Fazer isso com um conto longo seria mostrar apenas o que a crítica já colocara, e, portanto, repetir o mesmo, como uma tautologia, que o conto romântico é ruim porque é longo ${ }^{26}$. Por outro lado, o conto escolhido inicialmente tem algumas diferenças em relação aos seus congêneres contemporâneos por trazer uma linguagem muito mais contida em termos de imagens e metáforas do que se costuma ver, o que nos permite uma concentração maior no que queremos atingir, e o torna portanto mais significativo para a hipótese levantada. Por fim o conto, apesar das questões que observaremos, possui outros elementos produtivos de análise, em especial se nos referirmos ao ponto de vista e à temática. Há a se considerar que seu autor acabará por ter um papel de certo relevo para a literatura brasileira, apesar de mais por sua atuação cultural do que pela escrita, é verdade, mas ainda assim importante. Refiro-me a Francisco de Paula Brito (1809-1861), mestiço, jornalista, tradutor, escritor e editor, provavelmente

\footnotetext{
${ }^{24}$ É importante especificar que vários autores do período não tinham perfeita clareza do gênero em que se expressavam, em se tratando de gêneros modernos da prosa. A isso se refere Antônio Cândido quando analisa alguns de nossos primeiros prosadores, mostrando que ora designavam seus escritos de romance, ora de novela, sem que de fato se configurassem como tal. Num dos raros acertos desses autores, pode-se ver como se cria uma situação quase cômica. Como exemplo, o trecho seguinte é bastante eloquente: "Maria ou vinte anos depois, com a especificação de 'romance brasiliense', é uma obrinha, preciosa pelo valor documentário, que se poderia definir como romance-relâmpago, pois apesar do tamanho (onze páginas da Minerva Brasiliense, equivalendo talvez a umas trinta de formato comum) não é certamente novela nem conto". CANDIDO, Antônio. Formação da literatura brasileira: momentos decisivos. Vol.2. $9^{\mathrm{a} e d .}$ Belo Horizonte: Itatiaia, 2000, p.109.

${ }^{25}$ Cortázar novamente destaca a questão das qualidades do conto na análise que faz de Allan Poe. Diz o contista argentino: "Poe percebeu, antes de todos, o rigor que exige o conto como gênero, e que as diferenças deste com relação ao romance não eram só uma questão de tamanho. [...] Compreendeu que a eficácia de um conto depende da sua intensidade como acontecimento puro, isto é, que todo comentário ao acontecimento em si (e que em forma de descrições preparatórias, diálogos marginais, considerações $a$ posteriori alimentam o corpo de um romance e de um conto ruim) deve ser radicalmente suprimido". CORTÁZAR, op. cit., p.122.

${ }^{26}$ Maria Cecília Boechat, que também estudou o conto curto romântico, expõe a seguinte posição, fazendo referência a um conto de Casimiro de Abreu: "Porque, de fato, uma das qualidades da narrativa está no modo 'natural', 'fluente', com que se mostra já distanciada dos excessos que marcam a primeira prosa curta ficcional brasileira (e sempre tributados ao pretenso excesso sentimentalista de nossos prosadores românticos): excessos de adjetivação e de expansões derramadas que compõem o tom melodramático dessa produção inicial e que tanto desagradam aos leitores atuais. E que, ademais, explicariam a 'pobreza' de nossas primeiras manifestações na forma concisa do conto". BOECHAT, Maria Cecília. "Da ação folhetinesca à cena intimista: um conto romântico de Casimiro de Abreu". Teresa: revista de Literatura Brasileira [12|13]; São Paulo: Universidade de São Paulo, p. 271-286, 2013.
} 
o primeiro editor do Império, primeiro a publicar um jornal direcionado ao público feminino e primeiro a publicar um jornal sobre a questão do negro no país, $O$ Homem de Cor, em $1833^{27}$, sem contar a importância decisiva que terá para a biografia de Machado de Assis. De sua produção no gênero conto dispomos de apenas três textos, todos publicados no Jornal do Comércio do Rio de Janeiro, em formato de folhetim, em 1839. Dos três, abordaremos "Revelação póstuma", publicado nos dias 9 e 10 de março daquele ano.

A história se utiliza do gênero epistolar, tendo como voz narrativa a moça Carolina, que, em tom de confissão, conta a uma amiga sua angustiante história antes que a morte a tome. Inicia falando sobre sua família, pai e mãe apenas, que a criavam com todos os mimos que o dinheiro podia comprar, uma vez que eram uma família rica e só possuíam Carolina como filha. A moça não dava tanto valor ao que os pais lhe ofereciam e intentava tornar-se logo emancipada, embora ainda tivesse quinze anos. Logo surge um pretendente, Felício, elegante, de fino trato social e desejado por todas as moças solteiras da sociedade, que, no entanto, se veem preteridas em favor da bela Carolina. Contudo, a união não é do agrado do pai da moça, que não vê o rapaz com bons olhos, considerandoo um aventureiro. O pedido ao pai da mão de Carolina em casamento é então negado, o que acarreta a primeira reviravolta da história. $\mathrm{O}$ pretendente rejeitado marca uma fuga secreta com Carolina, o que possibilita que se casem. O pai enganado, como modo de esconder o delito à sociedade, aceita o casamento, embora não venha mais a tratar a filha como antes. Um ano após o casamento, a mãe de Carolina, sua única confessora, morre. Apesar disso, o casamento vai bem, os dois são abastados e o marido mantém Carolina no mesmo luxo a que já estava acostumada, embora ignorasse a fonte de renda do marido, o que motivava sua desconfiança em relação a ele. Após um idílio de dois anos, acidentalmente Carolina encontra um bilhete do marido a um amigo, em que confessa suas dificuldades financeiras em função de dívidas de jogo. A revelação abala a narradora que passa a questionar em silêncio as ocupações do marido, sem nada declarar a seu pai, por mero orgulho, já que ele havia sido contra a relação. As preocupações são aliviadas com os mimos que o marido lhe faz. Um dia, porém, em virtude de uma febre, resolve encontrá-lo, voltando para a cidade da chácara que ele havia comprado. Para sua surpresa, flagra uma de suas escravas, Isabel, na cama do casal. Carolina desmaia e quando acorda

\footnotetext{
${ }^{27}$ Para mais informações sobre a vida e o trabalho de Francisco de Paula Brito ver GODIN, Eunice. Vida e obra de Paula Brito "Iniciador do movimento editorial no Rio de Janeiro" (1809-1861). Rio de Janeiro: Livraria Brasiliana Editora, 1965.
} 
está sendo cuidada por seu pai e por seu marido. Nada do flagrante é dito, nem mesmo à escrava, que lhe serve humildemente. A traição é deixada de lado após seu marido lhe confessar que está endividado, mas que dará um jeito de sair dessa situação. Compadecida, Carolina retoma sua vida na chácara, agora com a presença mais constante de Felício, perdoando-o para si mesma, uma vez que o flagrante não fora revelado. A situação mantém-se estável até que a senhora volte a desconfiar de seu marido, produzindo um segundo flagrante, esse, público, perante todos os escravos da chácara, que recebem ordens de se livrarem de Isabel. Felício, no entanto, impede a ação, confessando a sua esposa que a escrava estava grávida de um filho dele. Carolina foge para a casa de seu pai, não lhe revelando a verdade da separação, que ela agora confessa na carta para sua destinatária, que terá a incumbência de mostrá-la ao pai de Carolina, que está tísica. A Felício ainda restará a perseguição policial por suas dívidas e por jogo ilegal antes de Carolina encerrar a carta.

O longo resumo acima é proposital e sintomático, pois é necessário indicar uma certa dificuldade em sintetizar uma história romântica desse tipo ${ }^{28}$. Há toda uma linha causal que articula os fatos e impede a omissão de alguns deles em função da clareza. Mas vamos tentar organizar alguns pontos. O primeiro aspecto se relaciona ao tempo da narrativa. A história dura cerca de dois anos e alguns meses, se considerarmos que inicia quando os dois jovens se conhecem até o desfecho do casamento, ignorando nesse sentido a puberdade idílica de Carolina, por ela referida, e os desdobramentos futuros das falcatruas de Felício, apontadas no final. Como tais, não pertencem à ação propriamente dita, embora indiquem elementos causais e consecutivos da narrativa. A ação central é o relacionamento entre Carolina e Felício, que dura pouco mais de dois anos. Digamos que a história de uma relação que culmina em um casamento e perdura até uma separação é relativamente longa, independente de quanto tempo de fato tenha durado. Nenhuma narração poderia deixar de se referir ao início do relacionamento e ao nascimento do amor do casal, às eventuais dificuldades de afirmação e suas superações, ao casamento em si, ao decantamento da paixão inicial até o desgaste gradativo que finda na separação. Para que o relato não gere um romance, mas somente um conto, é necessário um plano de seleção severo de quais elementos são essenciais em toda a história para que o contado

\footnotetext{
${ }^{28}$ Como parâmetro de comparação remeto ao longuíssimo resumo que Antônio Cândido faz do romancerelâmpago Maria ou vinte anos depois, de Joaquim Norberto, que lhe ocupa um longo parágrafo, ao que conclui, no início do seguinte: "É a complicação romântica em todo o esplendor, esteada pela maquinaria adequada: violência e cordura, bondade e maldade, alternando-se; incesto, coincidência, surpresa, reconhecimento por meio de sinais e, sobrevoando tudo, a Fatalidade”. CANDIDO, op. cit., p.109.
} 
cumpra uma função determinada em relação ao efeito esperado. De certa forma, Paula Brito se sai bem da incumbência, pois "Revelação póstuma" tem um tamanho semelhante a qualquer conto da segunda fase de Machado de Assis. A narração sintetiza algumas partes importantes de uma história desse tipo, ao observarmos, por exemplo, que a fase de enamoramento é referida de modo seco e até mesmo antirromântico:

Não te contarei como Felício foi ganhando terreno em meu coração, e como foi crescendo a minha ilusão; seria a história de todos os namoros ${ }^{29}$

Vê-se que é um salto considerável de tempo, uma vez que, em função de qual Felício a narradora pretende nos apresentar, seria contraproducente exibi-lo em seu momento mais louvável e simpático. Ele já fora apresentado anteriormente como um janota e é essa imagem que deve permanecer. O namoro aqui não importa, porque o reforço do lugar comum, como diz a narradora, não contribuiria para o efeito a que se quer chegar. Um processo de meses é reduzido ao extremo, porque a ação tem uma necessidade outra de andamento, é preciso chegar logo ao caminho que leva à meta. $\mathrm{O}$ trecho citado acima, em que meses são condensados, continua em seguida em uma cena, mostrada da seguinte forma:

bastará dizer-te que, no fim de algum tempo, uma noite que achávamos em casa a sós, eu, minha mãe e meu pai, este, com sorriso de mofa, contou a minha mãe que Felício tinha-lhe pedido a minha mão, e que fora rejeitado, acrescentando que, por sua vontade, nunca seria sua filha de um homem cujos meios de vida eram ignorados, cujos costumes ninguém sabia, podendo apenas chamar-se um moço do tom, da moda. ${ }^{30}$

Note-se que há uma economia narrativa enorme nesse trecho, que nos põe a par de uma situação de momento, introdutória de um conflito, ao mesmo tempo que nos informa da vida desregrada e mal explicada do rapaz, motivo da rejeição do pai da moça. É um mérito, não há dúvida. No entanto, há um excessivo delineamento na sequência temporal estabelecida pelo narrador. A mudança de tempo é sempre apontada de forma direta, com marcadores explícitos como "dois anos se passaram", mais de uma vez repetido, "nesse mesmo dia", "quinze dias passei”, "em uma tarde", "alguns dias se passaram", "algum tempo se passou", "uma madrugada", "um quarto de hora seria passado". Ao tomar o conjunto, nota-se uma predominância de termos indefinidos, pronomes, artigos indefinidos, verbos condicionais. A impressão que temos ao longo da leitura do conto é que o tempo da narração é muito mais estendido do que de fato é. O

${ }^{29}$ Jornal do Commercio, Rio de Janeiro, 9 e 10 de março de 1839.

${ }^{30}$ Idem. 
que durou dois anos parece ter durado seis, pela repetição enfadonha do "dois anos se passaram", e pela constante indefinição de um tempo cronológico na narrativa. Como a narradora, já em estado enfermo por conta de sua tuberculose, relata os acontecimentos de memória para sua destinatária, pensemos que é constantemente traída por suas reminiscências, que ora vêm detalhadas, ora vagas. Até aí o problema é verossímil. O que, entretanto, essa indefinição produz é um repetitivo anticlímax e afrouxamento do tecido narrativo, que dá saltos no tempo antes que o efeito dos acontecimentos narrados se cristalize. O casal se apaixona, o pai impede o casamento, os dois se casam em segredo. Dois anos se passam. $\mathrm{O}$ marido entra em dívidas, a mulher descobre e adoece, a mulher vai convalescer na chácara. Dias se passam. A mulher descobre a traição do marido e desmaia, a mulher volta para a chácara. Dias se passam. O marido volta a entrar em dívidas. Dias se passam. A mulher flagra o marido com a amante, vai para a casa do pai. Meses se passam. A história termina. A falta de habilidade aqui está em fazer o tempo passar de forma mecânica, como se fosse um empecilho para narrar o que realmente importa, os lances melodramáticos do enredo.

Contudo, não é apenas a disposição temporal que deixa o conto mais longo do que realmente é. Daí temos o segundo aspecto, que é o da ação. Friedman denomina a ação da seguinte forma:

Uma ação completa é, como vimos, uma ação de certo tamanho - seja um discurso, cena, episódio ou trama - contendo o que quer que seja relevante para conduzir o protagonista em etapas verossímeis ou necessárias desde o começo, passando pelo meio e indo até o final de uma determinada situação. ${ }^{31}$

Retomando a Poética, de Aristóteles ${ }^{32}$, o crítico traça um elemento essencial que é a sequência de fatos verossímeis dentro de uma situação dada. O problema da verossimilhança passa a ser um pressuposto da ação, que se move enfeixada num mecanismo de causas e efeitos necessariamente verossímeis, o que significa que, quanto mais se tiver que explicar causas e efeitos de uma ação, maior será seu tamanho. Em outro trecho, diz Friedman:

\footnotetext{
${ }^{31}$ FRIEDMAN, p. 226.

${ }^{32}$ Friedman coloca como epígrafe de seu estudo o seguinte trecho da Poética de Aristóteles: "Tal como é necessário que nas demais artes miméticas una seja a imitação, quando o seja de um objeto uno, assim também o mito, porque é imitação de ações, deve imitar as que sejam unas e completas... Todo é aquilo que tem princípio, meio e fim. Princípio é o que não contém em si mesmo o que quer que siga necessariamente outra coisa, e que, pelo contrário, tem depois de si algo com que está ou estará necessariamente unido. Fim, ao invés, é o que naturalmente sucede a outra coisa, por necessidade ou porque assim acontece na maioria dos casos, e que, depois de si, nada tem. Meio é o que está depois de alguma coisa e tem outra depois de si”. Op.cit., p.220.
} 
Então, o tamanho dessa ação irá depender do que o autor quer que seu protagonista faça ou sofra e do quanto, correspondentemente, ele deve adentrar nas experiências desse seu protagonista a fim de achar as causas que são necessárias e suficientes para motivar e dar crédito àquela ação. Claramente, uma ação dinâmica pode fazer uso de um número bem maior de causas do que uma ação estática, e uma mudança mais inclusiva irá requerer uma cadeia maior de causas do que uma menos inclusiva. Desse modo, uma ação, seja do tamanho que for, constitui um todo completo sempre que o delicado entrelaçamento de causas e efeitos englobar qualquer coisa que seja suficiente para tornar uma ação compreensível e verossímil. ${ }^{33}$

Em "Revelação póstuma" vemos que Paula Brito acaba permitindo um número de ações tais que, por necessidade de explicar suas causas e efeitos, termina por saturar a narração com mecanismos que sustentem a verossimilhança. Esquematicamente, podemos dividir o conto em três grandes partes, sendo a primeira o encontro de Carolina e Felício até o casamento à revelia da família, a segunda o endividamento do marido e sua obscura fonte de renda e a terceira o seu caso amoroso com a escrava Isabel, que é localizado em dois momentos. Reparemos que, para cada uma das partes, se faz necessária uma rede de causas e efeitos para sustentar a verossimilhança. Na primeira parte, o caráter leviano e mimado da moça Carolina e a frivolidade suspeita de Felício justificam a negativa do pai ao casamento e o consequente matrimônio às escondidas. A segunda, através da cena reveladora do bilhete, nos é detalhada pelo comportamento misterioso e furtivo do marido e o consequente afastamento de Carolina para a chácara. A terceira, já se aproveitando da presença da esposa na chácara, introduz a traição de Felício com Isabel, que culminará na cena digna de tragédia da revelação da gravidez da amante, motivo das saídas suspeitas de Felício. Se, por um lado, Paula Brito não tem o estilo arrebatado e grandiloquente que a crítica costuma atribuir aos românticos, por outro, cada lance do conto é emoldurado por uma cadeia de causas e efeitos que produz a sensação de uma história longa. É usado todo um parágrafo, por exemplo, para que se diga que Felício dormia na cidade e que Carolina não levantava nenhuma suspeita em relação ao fato. Há verdadeiramente nesse autor romântico, e provavelmente em outros, uma timidez na propriedade de aludir a fatos, situações e sentimentos. Tudo precisa ser contado em detalhes, como se uma única frase e suas inferências não fossem suficientes para dizer o necessário. Vejamos o trecho referido acima:

É chegada a ocasião de dizer-te que, quando eu estava na chácara, muitas noites dormia Felício na cidade, servindo-lhe de motivo a distância. Não me causava isso a menor perturbação; tanta confiança tinha eu nele, e eram tão deliciosos os momentos de suas chegadas, que a sua ausência de um ou dois

\footnotetext{
${ }^{33}$ Idem, p.222.
} 
dias era para mim um prazer. Depois do dia fatal de que acabei de te falar, a causa destas faltas me foi conhecida; e agora, quando a noite não aparecia, eu ficava na mais viva agitação; via-o sentado à mesa do jogo, nessas casas infames, cuja descrição tenho lido e ouvido; figurava-o entre homens das classes mais vis, disputando a quem mais ligeirezas faria; com os olhos fitos sobre o dado fatal, ou sobre a mão do terrível banqueiro, minha imaginação o pintava, já saltando de contentamento, já pálido como um cadáver de três dias... Supõe tu na ideia quanto puderes de mais triste, nada equivalerá aos tormentos da tua amiga. ${ }^{34}$

Há um acúmulo de imagens, que passam do que não causava "a menor perturbação" a um pesadelo contínuo, num crescente de dramaticidade que, se é verossímil em relação a situação em jogo, não significa que seja de todo necessário. Um outro trecho, após a descoberta da traição do marido com a escrava, também é sintomático do que afirmamos. A repulsa é exposta no primeiro parágrafo, que, no entanto, se estende em uma reflexão no segundo para ser concluído no terceiro, sem que a personagem chegasse a uma atitude:

Eis-me absorvida em minhas reflexões; meu pai as não perturbava, para me não fazer quebrar o silêncio. Já eu não via o jogador, não via o esposo infiel; era o ultraje de ver meu leito manchado por minha própria escrava.

- Que homem vil! dizia eu; se ao menos fosse fascinado por algumas dessas mulheres brilhantes que enchem nossos salões! Se ao menos a formosura o deslumbrasse! Se em uma de suas orgias noturnas se deixasse vencer por alguma dessas imundas prostitutas, que vendem seu corpo por dinheiro!... eu o pudera desculpar... Mas, que seduções, que atrativos pode ele encontrar em sua própria escrava? mulher que nunca pode elevar até a si, e, por consequência, que o obrigava a descer até ela!

Tanta baixeza de sentimentos me custava a conceber. E era o homem da moda, o homem do grande tom que, à porfia, era buscado para todos os salões! Quando Isabel aparecia, tinha vontade de mandá-la por de rastos fora de meu quarto; porém meu pai ali estava, meu pai que me prendia. E podes tu imaginar os meus tormentos? Se cada um me arrancasse uma lágrima, os olhos da tua amiga não bastariam para chorá-las. ${ }^{35}$

A ação em si, o olhar de repulsa e censura moral que Carolina, a senhora branca, dirige a Isabel, a escrava negra, é amplamente delineado em suas causas, de forte viés ideológico dentro de uma sociedade escravocrata, e que, embora ponha a frente esse viés, escancarando pela pena de um autor negro, como era Paula Brito, o componente sentimental nada ingênuo da senhora branca, faz da ênfase um libelo, que talvez pudesse ser mostrado de forma mais econômica, mas não menos enfática ${ }^{36}$. A multiplicação de

\footnotetext{
${ }^{34}$ Jornal do Commercio, 09 e 10 de março de 1839.

${ }^{35}$ Idem.

${ }^{36}$ Para outras abordagens sobre a questão racial e de gênero nos contos de Paula Brito, ver SILVA, Marcos Fabrício Lopes da. "Gênero e etnicidade nos contos de Francisco de Paula Brito: entre a submissão e o destemor”. In.: Terra Roxa e outras terras, vol.17-B, dezembro 2009, p.125-134; PORTO, Jakeline Longo.
} 
discursos, cenas e episódios melodramáticos, em que a reação sentimental pode por si parecer excessiva, provavelmente leva os autores românticos, e este conto é apenas um exemplo, a procurarem dar credibilidade a suas personagens e tramas mirabolantes dilatando a narrativa em apresentar causas e consequências, num afã de justificar, por motivações verossímeis, os arroubos inverossímeis de seus enredos.

Abordagem semelhante, mas em relação ao romance romântico, faz Karin Volobuef, em seu estudo Frestas e arestas: a prosa de ficção do Romantismo na Alemanha e no Brasil ${ }^{37}$, em que também aponta essa necessidade de verossimilhança, observando os vários procedimentos técnicos que os romancistas utilizam para sustentar a narrativa, tais como o personagem não-identificado, o vulto, oflash-back, a antecipação e o personagem oculto. Em todos eles, o intuito é o mesmo, amarrar os laços dramáticos da narrativa a fim de que o leitor, conduzido pelo suspense que criam, possa acompanhar o desenvolvimento das ações sem questionar sua verossimilhança ${ }^{38}$, uma vez que estão entrelaçadas nas suas causas e efeitos. Outro aspecto importante levantado por Volobuef é em relação ao estatuto dos narradores, que procuram proporcionar uma verdade ao que narram, sejam eles oniscientes ou não, em primeira ou terceira pessoa, reforçando a questão da verossimilhança.

Essas linhas de Alencar [referindo-se a um trecho de Lucíola] já deixam entrever um dos objetivos centrais do narrador intruso: criar uma impressão de verossimilhança. Essa ideia - de que o texto seria uma história verídica ajuda a criar um sentimento de empatia entre leitor e personagens: o leitor identifica-se com as figuras ficcionais porque vê nelas verdadeiros seres humanos, e passa a agir e sentir com elas. ${ }^{39}$

No conto de Paula Brito, alguns desses aspectos abordados por Volobuef também estão presentes, e todos voltados especialmente para a construção da verossimilhança, no mesmo sentido de que se intenta criar uma empatia e proximidade

Francisco de Paula Brito: um precursor da narrativa brasileira no século XIX. Dissertação de Mestrado. São José do Rio Preto: UNESP, 2017.

${ }^{37}$ VOLOBUEF, Karin. Frestas e arestas: a prosa de ficção do Romantismo na Alemanha e no Brasil. São Paulo: UNESP, 1999.

${ }^{38}$ Posição semelhante apresenta Antônio Cândido na Formação da literatura brasileira, vinculando-a a um motivo de ordem social e determinista: "Tanto num quanto noutro [romantismo e naturalismo] porém, permanece o esteio da verossimilhança e, mais fundo, a disposição comum de sugerir certo determinismo nos atos e pensamentos do personagem. A insistência dos naturalistas no determinismo inspirado pelas ciências naturais não nos deve fazer esquecer o dos românticos, de inspiração histórica. Com matizes mais ou menos acentuados de fatalismo, uns e outros se aplicavam em mostrar os diferentes por que a ação e o sentimento dos homens eram causados pelo meio, pelos antecedentes, a paixão ou o organismo. Daí um realismo dos românticos, que apenas seria desnorteante se não lhe correspondesse um patente romantismo dos naturalistas, para fazer da ficção literária no século XIX, e da brasileira em particular, um conjunto mais coeso do que se poderia supor à primeira vista". CÂNDIDO, op. cit., p.98.

${ }^{39}$ VOLOBUEF, p.263. 
realistas com o leitor, que ao acreditar na veracidade de uma história, identifica-a também como próxima de si, dentro de um processo de espelhamento e satisfação propiciado por uma literatura cujo público é formado essencialmente pela burguesia escravocrata do segundo Império no Brasil.

Vejamos agora como a questão da estrutura do conto se dá em outro autor romântico, um pouco posterior, que a crítica considera que teria conseguido atingir uma forma relativamente mais madura do conto. Trata-se de Álvares de Azevedo (1831-1852) e seu Noite na taverna $(1855)^{40}$, cuja estrutura envolve o uso de uma narrativa moldura, que enfeixa as demais narrativas contadas por suas personagens reunidas em uma taverna, devidamente inspiradas por muito vinho, ao estilo das histórias do Decameron, de Boccaccio $^{41}$. Apesar desse modelo, é possível isolar cada história contada por cada narrador, uma vez que não possuem ligação entre si, sendo inclusive cinco delas, de um total de sete, intituladas pelo nome de seus narradores. Advirta-se que nossa leitura de um dos contos de Noite na taverna não entrará em discussões críticas sobre a natureza do gênero dessas histórias, se fantásticas ou não, nem mesmo nos preocuparemos com suas supostas influências de Byron, Hoffmann e outros autores, o que tem sido discutido com certa frequência pela crítica. Nosso propósito aqui, através da leitura do conto Bertram, terceiro capítulo do livro, é analisar de que maneira, já com o romantismo brasileiro em sua fase mais característica e popular, a do ultrarromantismo, um autor do porte de Álvares de Azevedo vem a compreender a forma do conto, mobilizando a capacidade de síntese narrativa, pensando no elemento que Regina Pontieri destaca em sua análise da teoria de Poe, que é "a brevidade decorrente do rigoroso ajuste dos meios aos fins"42. Embora a estrutura do livro como um todo fuja a nossa discussão, a autonomia de suas partes e a relativa consideração dada pela crítica ao autor de Noite na taverna nas histórias do conto no Brasil ou nas antologias do conto romântico favorecem que o utilizemos como exemplo.

\footnotetext{
40 AZEVEDO, Álvares de. Noite na taverna. 5ª ed. Rio de Janeiro: Francisco Alves, 1991.

${ }^{41}$ A ideia da narrativa com moldura, segundo Auerbach, foi trazida do Oriente à Europa, inicialmente sendo utilizada como meio para exposições didáticas ou morais, tendo as novelas como exemplos. Boccaccio é quem teria dado a essa moldura um aspecto mais orgânico, fazendo-a parte de um universo social. A diluição desse princípio tornou-a obsoleta, embora imitada por muito tempo, como o faz Álvares de Azevedo. Sua morte está ligada à autonomia da novela que, "livre de quaisquer constrangimentos, pôde ser narrada por si mesma”. AUERBACH, op. cit., p.21.

${ }^{42}$ PONTIERI, Regina. "Formas históricas do conto: Poe e Tchekhov". In.: Ficções: leitores e leituras. Org. Viviana Bosi et ali. Cotia: Ateliê, 2001, p.92.
} 
Apenas um breve resumo do conto, uma vez que é bem mais conhecido que os de Paula Brito e seu acesso bem mais facilitado: o narrador, Bertram, após ouvir a história de Solfieri, levanta-se e passa a contar a história de uma dama de Cádiz, na Espanha, chamada Ângela, pela qual se apaixonou, mas que, logo após conquistá-la, teve que abandonar para visitar seu pai moribundo na Dinamarca. Dois anos após a morte de seu pai, quando retorna, encontra sua amada casada e mãe de uma criança. Apesar disso, retomam secretamente a relação voluptuosa que tinham, até a descoberta da traição pelo marido de Ângela. Apaixonada, a mulher mata seu marido e seu filho, apresentando os cadáveres ao narrador horrorizado. Após o assassinato, os dois partem em viagens intermináveis até que Ângela o abandona. Bertram se entrega ao vício e, uma noite, após um acidente, é recolhido por um velho rico e sua filha de dezoito anos. Ao fim de sua convalescença e enfeitiçado pela beleza da menina, foge com ela após desvirginá-la. Não demora para que se canse dela e então a venda para um pirata, que é assassinado pela moça, que se lança ao mar. Tempos depois, ao tentar o suicídio, Bertram é resgatado pelo capitão de um navio, cuja esposa impressiona o narrador, tornando-se sua amante. Após um naufrágio ocasionado pela abordagem de piratas, Bertram, a mulher, o capitão e dois marinheiros se veem à deriva no mar em uma pequena embarcação. Tolhidos por uma tempestade, restam apenas Bertram e o casal. Oprimidos pela fome e após uma luta sangrenta, Bertram mata o capitão e pratica canibalismo com seu corpo. Pouco depois é a moça quem morre e Bertram é resgatado por um navio inglês.

Apesar do resumo não ser tão breve quanto o prometido, o conto de Bertram também não é tão longo quanto parece. Assim como o de Paula Brito, tem um tamanho equivalente aos melhores contos de Machado de Assis. No entanto, novamente a questão aqui não é o tamanho do conto e sim sua capacidade ou não de síntese com vista a um efeito. O que há aqui que, se satisfaz como narrativa (lembre-se que Noite na taverna foi bastante lida e emulada por gerações posteriores), não convence como conto ${ }^{43}$ ? Friedman talvez possa nos vir em auxílio, uma vez que o conto de Bertram envolveria a mudança de uma personagem. Diz Friedman:

\footnotetext{
${ }^{43}$ Usamos o termo narrativa no sentido especificado por Todorov, ou seja, história de ficção contada em prosa, cujos aspectos obedecem aos princípios da sucessão, especificamente de ações dentro do tempo, e transformação, mudança ocasionada ou não pelas ações, mas possuindo um princípio de diferenciação de um estado anterior. O termo conto, aqui, se estabelece como um gênero da narrativa. TODOROV, Tzvetan. “Os dois princípios da narrativa". In.: Os gêneros do discurso. Trad. Elisa Angotti Kossovitch. São Paulo: Martins Fontes, 1980. Embora usemos a terminologia de Friedman, ela tem estreitas relações com a teoria de Todorov.
} 
Outra questão que se refere ao tamanho é se a ação envolve ou não uma mudança e, se de fato envolver, se essa mudança é fundamental ou secundária, e simples ou complexa. ${ }^{44}$

A mudança complexa seria aquela que necessitasse de várias ações subsequentes para sua ocorrência plena, e a simples, evidentemente, a que precisasse de poucas ações. Como se supõe, e Friedman assim explica, quanto mais ações necessárias para uma mudança, maior a possibilidade que a história seja mais longa. A afirmação não é mecânica, obviamente, uma vez que se pode inverter essas relações, mas é como em geral uma história se configura, tornando as distinções entre conto, novela e romance um pouco menos espinhosas. O ponto principal aqui, possivelmente, trata do que se pode chamar de concentração, ou seja, o quanto uma história focaliza uma mudança, ou mudanças, e o quanto ela se expande a partir delas mesmas ${ }^{45}$. A tendência é julgar que o conto, em geral, novamente, terá uma concentração em um número menor de mudanças e, para cada uma delas, dedicará uma expansão reduzida de ações necessárias para que aconteçam, daí advindo a famigerada capacidade de síntese do gênero. Reparemos que não tem a ver com a quantidade de palavras utilizadas, mas sim com o modo como elas serão dispostas.

O modo de Álvares de Azevedo certamente daria um romance. Não porque a história abarca vários anos. A de Paula Brito também recobre um longo espaço de tempo. A cartomante, de Machado de Assis, publicado pela primeira vez na Gazeta de Notícias do Rio de Janeiro, em 1884, gasta oito linhas para saltar da infância de Camilo e Vilela, passar por suas carreiras, até chegar ao reencontro dos dois em 1869. Após isso, duas páginas e meia para narrar o caso de amor de Camilo com a esposa de Vilela, que já durava muitos meses. As nove páginas restantes tratam só de algumas semanas ${ }^{46}$. Em Álvares de Azevedo, a questão não reside na forma de lidar com o tempo, que pareceu mais sintomática em Paula Brito, mas o modo como encadeia as ações visando demonstrar a mudança por que passa a personagem. E, mais uma vez, o ponto nevrálgico vai ser a necessidade de verossimilhança. Voltemos a Friedman:

\footnotetext{
${ }^{44}$ FRIEDMAN, p. 224.

${ }^{45}$ Em seu estudo referido anteriormente, Pontieri se utiliza do termo concentração com uma conotação um pouco diferente. Ainda comentando a teoria de Poe, diz que "é na condição de dichter, termo com que o alemão designa tanto o poeta como o condensador, que Poe definirá a concisão, concentração, como os traços próprios do Belo na obra de arte”. Op. cit., p.92. Em Pontieri o termo se aproxima mais da questão da brevidade, enquanto aqui o utilizamos mais próximo da noção de foco.

46 ASSIS, Machado de. Várias histórias. Edição preparada por Hélio de Seixas Guimarães. São Paulo: Martins Fontes, 2004.
} 
Espero agora que já esteja claro que um conto pode ser estático ou dinâmico, apesar de, como vimos, uma ação estática normalmente requerer menos partes do que uma que é dinâmica e que irá, portanto, normalmente ocupar menos espaço na narrativa. Isso quer dizer que uma história estática simplesmente apresenta seu protagonista em uma ou outra situação e inclui apenas o suficiente para revelar ao leitor a causa ou causas das quais essa situação é consequência, enquanto uma história dinâmica conduz seu protagonista através de uma sucessão de duas ou mais situações e, assim, deve incluir muitas causas das quais essas situações são consequência. Logo, uma história estática normalmente é mais curta do que uma dinâmica. ${ }^{47}$

O conto de Bertram é uma história dinâmica, uma vez que as ações são baseadas numa cadeia de causas e consequências que movem a história em cenas e episódios a serem sequenciados por tal lógica. Tudo deve levar a uma meta anunciada pelo narrador, a de uma história horrível. A construção desse horror vai necessitar de um alicerce verossímil, que dissipe qualquer incredulidade quanto à cena final, assim como tensione o leitor ao percebê-la como possibilidade, intensificando a sensação. De certa forma, é um dos objetivos da literatura que esse autor romântico leu e usou como referência, se o filiarmos a Byron, a Hoffmann, à literatura gótica de tradição inglesa que já vinha do século anterior. Mas, talvez seja necessário dizer que a sensação produzida pelo conto advém mais da ambientação produzida pelo narrador em suas digressões e adjetivações, e da singularidade das temáticas apresentadas (suicídio, infanticídio, canibalismo), do que da estruturação das ações sequenciadas. A narrativa de Álvares de Azevedo, em suas poucas páginas, introduz um número de episódios e cenas que formam, em seu conjunto, a trama da aventura macabra de Bertram diante das agruras de três mulheres. A impressão de romance, ou de pelo menos uma novela, paira sobre a leitura, que se ressente do fato de que as ações necessárias ou foram sumariamente abortadas em seus efeitos ou parecem boiar à deriva entre os episódios. Contraditoriamente, pode-se dizer que há uma sensação de que a história é muito longa, embora parte de seus episódios seja extremamente condensado. Se para o todo é necessário entender que Bertram passou por uma grande decepção amorosa para se tornar o ser vil que descreve, por outro, suas motivações parecem advir mais de caprichos do que de uma personalidade forjada pelo sofrimento. O episódio da moça do castelo, que Bertram desvirgina e vende a piratas, e que é utilizado para expor a transformação por que passara o narrador, é trabalhado de forma extremamente sintética, como uma espécie de parêntese, que fará a ligação entre a decepção amorosa da primeira parte e o abominável da terceira. Parece haver uma necessidade dessa segunda parte, bem pouco convincente no sentido estrutural do conto,

\footnotetext{
${ }^{47}$ FRIEDMAN, p.224.
} 
uma vez que a partida de Ângela já ocasionara a transformação do caráter de Bertram. A sucessão de episódios narrando as trágicas histórias dessas três mulheres em um único conto certamente é uma questão a ser colocada em termos da eficácia da narrativa enquanto conto, se pensarmos que para cada uma poderia haver um conto independente, focando no crime de Ângela no primeiro, no desgosto da pobre menina abandonada, e sem nome, no segundo, e no indecoroso desfecho antropofágico no terceiro. Aqui, a concentração foi dispersa em três linhas narrativas que possuem uma relação de causa e efeito, não há dúvida, mas que, devido a um segundo aspecto, se sustentam a verossimilhança dos acontecimentos, produzem um afrouxamento dos efeitos da história. E qual seria esse segundo aspecto?

O segundo aspecto é o próprio caráter da mudança como consequência da profusão das ações dinâmicas no conto. Isso significa que, paradoxalmente, apesar de ser um movimento literário em que a subjetividade e o sentimento adquirem toda a liberdade, o romantismo em prosa, em especial no conto, concentra a sua eficácia narrativa em exterioridades, ou melhor dizendo, a ação externa e dinâmica, que necessita de uma rede maior de causas e efeitos, e que, portanto, como base da verossimilhança das histórias românticas, é mais utilizada, não permite que a mudança ocorra a partir de uma cadeia de efeitos internos, com ações estáticas, em que o elemento de verossimilhança surja a partir da própria dinâmica psíquica da personagem. Bertram muda de mal para pior, mas não sabemos nada do que ocorre internamente com ele, pois tudo é uma consequência dos acontecimentos externos. O que lhe vai dentro é mistério. Mesmo sendo um narrador em primeira pessoa, percebe-se que Bertram ignora a si mesmo. Não poderia mesmo se autoconhecer em tal montanha russa de acontecimentos. Bertram olha para o mundo e mergulha nele. É egocêntrico e autocentrado, mas o olhar que tem para si é vesgo. Não há profundidade psicológica e construção de uma verossimilhança a partir de dentro, porque não há espaço estrutural para isso. O narrador precisa dar conta de uma cadeia ininterrupta de ações dinâmicas que lhe tolhem a visão concentrada, e aí os episódios se repetem como num teatro de melodrama, que Machado de Assis irá tão bem satirizar duas décadas depois no conto "A chinela turca", como ainda veremos.

No entanto, mesmo Machado não atingiu o patamar que o fez um contista de vulto universal também tão facilmente. $\mathrm{O}$ autor escreveu contos desde "Três tesouros perdidos", publicado n'A Marmota, em 1858, quando tinha ainda 18 anos e, a partir de 1864, quando começou a colaborar no Jornal das Famílias, passou a dedicar-se 
regularmente ao gênero. Mas sua produção deste período ainda se ressente de diversos aspectos problemáticos em relação à forma do conto, que a torna, segundo a crítica, inferior aos contos posteriores a Papéis avulsos, de $1882^{48}$. Vamos então analisar um desses contos e tentar compreender de que maneira Machado vinha elaborando a forma naquele momento de fim do período romântico no Brasil, já às portas da década de 1870 .

"Frei Simão" carrega um aspecto curioso dentro dos Contos fluminenses, de 1869, primeiro volume de Machado de Assis dedicado ao gênero. Essa curiosidade não advém de sua temática, a história de um amor impossibilitado por razões sociais e manipulado por mentiras, o que aliás seria a tônica de quase todos os contos do volume, como sugere Alfredo Bosi ${ }^{49}$, mas pelo simples fato de ser um texto curto junto a um grupo de narrativas de fôlego relativamente extenso. Na edição que utilizo ${ }^{50}$,"Frei Simão" ocupa 13 páginas. A história que mais se aproxima desse número é "Luís Soares", que abrange 36 páginas. "Linha reta e linha curva" é um "conto" de 76 páginas!

A curiosidade, em si, pode parecer mero acaso, não há dúvida, uma vez que a estrutura de "Frei Simão" é bastante semelhante à das outras narrativas do livro: segmentação em capítulos, uma trama estendida no tempo e um apego ao gênero folhetinesco usual que Machado utilizava para escrever no Jornal das famílias, periódico onde o conto foi inicialmente publicado. No entanto, talvez seja exatamente o conjunto de semelhanças apontadas que chame a atenção para a diferença de tamanho. No volume seguinte que publicaria, Histórias da meia-noite, que sairia em 1873, Machado também não economizaria páginas.

A história, como outras que o autor publicou no período, não tem aspectos muito acentuados de originalidade. Ela se encaixa perfeitamente no perfil das que escreveu para o Jornal das famílias, com uma trama romântica de lances inesperados e melodramáticos. A experiência teatral do autor de satisfazer uma burguesia carioca ainda

\footnotetext{
${ }^{48}$ É, por exemplo, a posição de Sonia Brayner, que, em Labirinto do espaço romanesco, afirma: "Os contos publicados até 1880 - Contos fluminenses (1870) e Histórias da meia-noite (1873), fruto de sua colaboração no Jornal das Famílias, acham-se dominados por um sentimentalismo romântico e por uma concepção ficcional ainda diversa da concisão, destreza comunicativa, variedade formal e humour que serão sua posterior escolha. São contos longos e subdivididos em partes, quase novelas, não fosse a manutenção da linearidade simples do enredo". BRAYNER, Sonia. Labirinto do espaço romanesco: tradição e renovação da literatura brasileira, 1880-1920. Rio de Janeiro: Civilização Brasileira/INL, 1979, p.66.

${ }^{49}$ Refiro-me ao já conhecido estudo de Alfredo Bosi, "A máscara e a fenda". In.: BOSI, Alfredo. O enigma do olhar. São Paulo: Ática, 2000, p.73-126.

${ }^{50}$ ASSIS, Machado de. Contos fluminenses. Edição preparada por Marta de Senna. São Paulo: Martins Fontes, 2006.
} 
embebida no melodrama falava alto naquele momento. Nesse sentido, pode-se dizer que Machado praticava um gênero de moda, que fazia suspirar as moças solteiras e acalentar as casadas, que representavam uma parcela importante do público leitor do jornal ${ }^{51}$, mas que certamente devia aborrecer os moços pelo açucarado da trama. A história do amor interdito pelas necessidades sociais, como é o fulcro da desdita do frade de Machado em "Frei Simão", era tema deveras comum entre os escritores românticos, e o autor carioca não se preocupa muito em disfarçar a obviedade da escolha.

Relembremos: nessa história temos dois planos de narração: um, o que forma a moldura da história, em que se conta a morte de frei Simão e se questiona sobre seu comportamento taciturno e antissocial, no qual o narrador emite suas opiniões acerca do frade e de aspectos de sua vida; o outro, o que é informado através dos manuscritos deixados pelo frade quando de sua morte e que são apropriados pelo narrador, que os utiliza segundo um critério próprio, eliminando o que lhe parecia inútil e obscuro. Esses elementos, evidentemente, explicitam a relação de manipulação que ocorrerá entre o relato biográfico, confuso e lacunar, escrito por frei Simão, e o uso que dele fará o narrador da história, que por selecionar o que lhe convém, modifica o gênero original dos escritos do frade, transformando o relato biográfico em narrativa melodramática, e preocupando-se de forma mais sistemática e racional com a questão da verossimilhança.

Temos assim um primeiro elemento dentro da história no que tange ao gênero: a modificação da memória biográfica em narrativa linear. O que pretende o narrador é dar ordem ao caos, proporcionar legibilidade a um escrito ilógico e incoerente, uma colcha de retalhos de uma vida que em algum momento perdeu seu sentido. Nesse ponto, o narrador é claro: o que ele encontrou nada mais eram que "fragmentos incompletos,

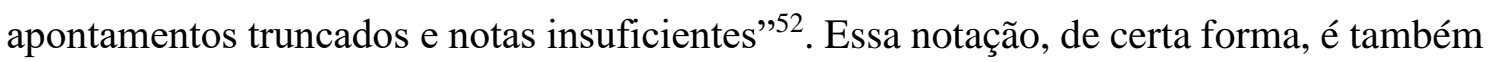
uma espécie de salvo conduto que lhe permite agir sobre o manuscrito conforme seu entendimento, omitindo e até mesmo acrescentando informações:

No manuscrito do frade há uma série de reticências dispostas em oito linhas. Ele próprio não sabe o que se passou. Mas o que se passou foi que, mal conhecera Helena, continuou o frade o discurso. Era então outra cousa: era um

\footnotetext{
${ }^{51}$ Para uma visão mais completa sobre a posição da mulher na sociedade do século XIX, ver COSTA, Emília Viotti da. "Patriarcalismo e patronagem: mitos sobre a mulher no século XIX", último capítulo de Da Monarquia à República: momentos decisivos. 9ªed. São Paulo: Editora UNESP, 2010.

${ }^{52}$ ASSIS, 2006, p.287.
} 
discurso sem nexo, sem assunto, um verdadeiro delírio. A consternação foi geral. ${ }^{53}$

Essa manipulação de gênero praticada explicitamente pelo narrador dará o mote para que outras interferências semelhantes aconteçam, tornando a história uma espécie de laboratório em que diferentes gêneros textuais - a hagiografia, o melodrama, o conto emerjam para receber novas configurações, mas que não são ainda totalmente apropriados para o objetivo. Portanto, o que se pode ver na história de frei Simão é uma síntese ainda incipiente do que viria a ser uma prática constante na obra de Machado, que é a manipulação e mistura de diversos gêneros textuais ${ }^{54}$, que se articulam em função de uma síntese, pois precisam se livrar do que é inútil e obscuro.

Citamos a questão das memórias do frade, das quais o narrador monta sua história por seleção, combinação e imaginação. Atribuímos o fato de não as usar integralmente à loucura então evidente do frade, omitindo a própria característica da memória, que é o de ser cumulativa e fragmentária, sem uma estrutura necessariamente lógica, no sentido de causas e efeitos. A narração exige essa sequência lógica, o que não se pode exigir da memória insana do frei. A mudança de gênero, nesse sentido, é proposital, porque visa reconfigurar fatos com o propósito de adaptá-los a um novo público leitor, não integralmente nomeado, mas que certamente faria parte da "comunidade curiosa" citada pelo narrador. O que se destaca, portanto, é o pitoresco, o novelesco de uma vida que por si só não daria um bom romance.

E a história de frei Simão tem como ponto de partida um romance, famosíssimo romance que nos séculos XVIII e XIX fez fama na Europa. Trata-se da novela epistolar Abelardo e Heloísa ${ }^{55}$, que conta os amores infelizes entre os dois personagens do título, que trocam cartas após serem separados definitivamente. Os dois, então confinados em serviços religiosos (ela num convento, ele num mosteiro), produzem uma significativa

\footnotetext{
${ }^{53}$ Idem, p. 296.

${ }^{54}$ Lembremos que a questão da fusão dos gêneros já havia sido colocada, por exemplo, por Victor Hugo, em 1827. Não é Machado quem elabora o procedimento. Advinda do romantismo, evidente que essa mistura de gêneros possuía relação direta com a necessidade de liberdade criativa apregoada pelos românticos, que procuravam se livrar das amarras limitadoras dos gêneros herdados do classicismo. Novamente, a questão não será o procedimento em si, mas o modo como cada autor o utiliza. Em "Frei Simão" ainda incipiente, como disse; porém, ali podemos perceber um campo de testes para o que Machado conseguiria poucos anos depois. Quanto ao histórico desse hibridismo, resumidamente, ver BASTAZIN, Vera. "Do ato de contar ao metaconto: recorrências e transformações dos gêneros literários em Machado de Assis". In.: Recortes machadianos. Org. Ana Salles Mariano e Maria Rosa Duarte de Oliveira. São Paulo: EDUC, 2003, p.181210.

55 ABELARDO, Pedro. Correspondência de Abelardo e Heloísa. Apresentação de Paul Zumthor. Trad. Lúcia Santana Martins. São Paulo: Martins Fontes, 1989.
} 
troca epistolar que depois de reunida produzirá a narrativa que tanto sucesso fez. Não cabe nos estendermos sobre essa obra, basta apenas colocá-la em vista para que possamos discutir alguns aspectos de "Frei Simão". A obra é citada textualmente pelo narrador quando Simão inicia sua correspondência com Helena, a prima por quem se apaixonara e de quem fora separado porque seu pai não pretendia que o filho se casasse com uma agregada. A citação de Abelardo e Heloísa não é gratuita, uma vez que o paralelo entre as histórias se dará com a entrada de Simão para uma ordem beneditina, assim como os amantes medievais abandonaram a vida mundana. O que o narrador fará aqui, porém, não será imitar a história fatídica de Abelardo e Heloísa ao pé da letra, reproduzindo suas cartas e conduzindo tudo à tragédia, mas, como já fizera com os manuscritos do frade, dará nova linha às cartas trocadas entre Simão e sua prima Helena. Apenas cita essa correspondência, que chegou a vinte cartas antes que fosse descoberta, sem, no entanto, usá-la diretamente. Curiosamente, o único uso textual que faz de uma carta é a do pai para o filho, em que lhe é comunicada a falsa morte da prima e lhe é pedido o retorno para casa. O episódio das cartas enforma o curto capítulo 3, e a maneira como o narrador procede, condensando meses em pouco espaço e utilizando das cartas somente aquilo que era mais direto e econômico para o andamento da história, denotam a habilidade do narrador em se aproveitar de um gênero enquanto funcional para o seu propósito narrativo. Tudo é econômico e lacunar, talvez, e principalmente, porque o conteúdo de tais cartas seria já do conhecimento do senso comum do público, habituado a tais novelas epistolares. Machado faz um exercício aqui que ainda praticará muito melhor posteriormente, que é o de não dizer o que não precisa ser dito, o que, sabemos, se transformará em algo muito mais complexo através da ironia, que diz sem dizer. Vemos claramente o narrador manipulando a estrutura do conto.

Outro elemento importante de que o narrador faz uso, se quisermos entender o que Machado está visando atingir, ou seja, a questão do verossímil, é quando nos apresenta a personagem Amaral, cúmplice do pai de Simão no engodo que lhe é tramado. $\mathrm{Na}$ carta que envia ao amigo solicitando sua ajuda na questão que o envolve com os amores do filho, diz o pai:

Você, que teve na sua adolescência a triste ideia de engendrar romances, vá inventando circunstâncias e ocorrências imprevistas, de modo que o rapaz não me torne cá antes de segunda ordem. ${ }^{56}$

\footnotetext{
${ }^{56}$ Idem, p.292.
} 
Repare que o pai manda o filho romântico aos cuidados de um ex-romancista, por sua vez experiente não apenas na arte amorosa, mas também na arte de inventar "circunstâncias e ocorrências imprevistas", o que certamente o qualifica como a pessoa adequada para ludibriar os delírios românticos do rapaz, dada sua capacidade imaginativa, oposta às características pragmáticas e mercantis do pai de Simão. É possível aproximar o comentário do comerciante à dura crítica que Machado fará anos depois, em 1878, ao romance $O$ primo Basílio, de Eça de Queiroz, em que atacará a "incongruência" da concepção romanesca ao inventar episódios que nada acrescentam ao aprofundamento de caráter das personagens ${ }^{57}$. Em "Frei Simão", o pai chama o artificialismo do método em seu socorro, supondo que de alguma forma aquela bobagem de adolescência que o colega praticara agora poderia ter realmente uma função utilitária. Visando outra meta, evidente, o pai critica o romance artificial, baseado nas reviravoltas do enredo, comum à literatura da época, de larga imaginação e escassa veracidade, como nos mostrou Antônio Cândido ${ }^{58}$. O que veremos, no entanto, é que o procedimento criticado será usado na história, em que lances do acaso levarão a trama a uma grande complicação, produzindo o impacto melodramático que o pragmatismo do pai quisera evitar.

Machado está ainda tateando possibilidades, mas já é possível ver, nessa história em especial, dado o modo como ele tenta exercitar a síntese, que o uso de outros gêneros textuais será um caminho para produzir funcionalidade na narrativa, visando especialmente os interesses de um narrador que, crítico e consciente de seu ofício de contar uma história, usa os modelos desconsiderando as regras, ou melhor, formulando suas próprias regras. "Frei Simão" é, no fundo, um romance com o tamanho de um conto, dada a profusão de episódios que constituem a trama, segundo a tipologia de Friedman, e Machado parece saber disso. O condensamento dos caracteres, as lacunas temporais, os lances surpreendentes de enredo, se devem algo de suas qualidades ao formato do folhetim que o autor praticou, também devem a uma busca de expressão cada vez mais incisiva e econômica dos meios utilizados, dizendo mais com menos. O enredo que montou em "Frei Simão" daria um longo romance, talvez uma hagiografia. Mas o caminho de Machado já era outro, principalmente porque sua consciência crítica lhe dizia

\footnotetext{
57 O Cruzeiro, 16 e 30 de abril de 1878.

${ }^{58}$ Em especial, no capítulo em que trata da influência do folhetim sobre os escritores românticos, Cândido apontará o valor superfaturado da peripécia em relação ao personagem, "que serve ao acontecimento". Apesar de estar se referindo aos primeiros prosadores românticos, bastante inábeis na questão, o procedimento será de uso comum por todo o romantismo, tendo sido uma "conquista da ficção moderna" derrotar a "cinemática da história". CÂNDIDO, op. cit., p.113.
} 
que algo girava em falso naquele modo de escrever que vinha praticando, o que o artigo contra Eça de Queiroz deixará explícito anos depois. Aqui ele ainda não encontrou o ponto, mas sem dúvida a formulação da nota de advertência de Várias histórias, que só seria publicado em 1896, já pairava sobre seus escritos:

O tamanho não é o que faz mal a este gênero de histórias, é naturalmente a qualidade; mas há sempre uma qualidade nos contos, que os torna superiores aos grandes romances, se uns e outros são medíocres: é serem curtos. ${ }^{59}$

O que ainda faltava à forma do conto, no caso de Machado, talvez tivesse que ser aprendido de outras fontes, que não pertencessem a uma visão melodramática que tanto impregnou o romantismo no Brasil. Por isso, seria fundamental observarmos outros elementos que possam ter contribuído para que o conto atingisse a forma madura que constatamos quando da publicação de Papéis avulsos em 1882.

\footnotetext{
${ }^{59}$ Várias histórias, op. cit.
} 


\section{DISSONÂNCIAS AO FIM DO ROMANTISMO}

Pode-se dizer que o gênero conto no Brasil tem uma história sui generis. Machado de Assis, no seu "Instinto de Nacionalidade" $(1873)^{60}$, dedica só um pequeno parágrafo a ele, cujo período final, frequentemente citado pela crítica, sugere que, naquele momento, o motivo de seu descrédito baseava-se em uma espécie de paradoxo: os escritores se afastavam do conto por lhes parecer um gênero fácil, de somenos importância, portanto, mas que, em sua essência, traria enormes dificuldades ${ }^{61}$. Por sua vez, o público, notando o desinteresse dos escritores pelo gênero, também não lhe daria maior crédito. O que está implícito na crítica de Machado, tanto em relação ao público quanto aos escritores, é o desconhecimento das características primordiais do conto, que não só atestaria sua dificuldade, mas também lhe facultaria um novo horizonte de status num panteão literário. Chama a atenção que em um artigo tão fundamental como "Instinto de nacionalidade", em que Machado faz uma panorâmica sobre a produção brasileira de então, ele tenha reservado tão pouco espaço - um parágrafo apenas - para um gênero que praticava desde 1858 e do qual já havia lançado uma coletânea e lançaria a segunda naquele mesmo ano. No capítulo anterior, vimos que, já em 1894, na enquete de $A$ Semana, contos que só haviam sido publicados em periódicos, no período romântico, como os de Casimiro de Abreu e Fagundes Varela, ainda eram lembrados. A pouca importância e o pouco espaço reservados ao conto no artigo de 1873 se explicariam apenas por uma indiferença do público ao gênero, ou por um suposto desdém dos escritores? Ou ainda, como Machado permite entrever, mas não afirma, a dificuldade de sua fatura seria sua principal barreira? Um pouco antes, no mesmo artigo, Machado se referira ao despreparo da crítica brasileira do período, que não era "doutrinária, ampla, elevada"62 , como ele já observava, em comparação com a crítica que vinha da Europa e, talvez, também dos Estados Unidos ${ }^{63}$. A importância que a crítica teria para o

\footnotetext{
${ }^{60}$ ASSIS, Machado de. O ideal do crítico. Organização e apresentação de Miguel Sanches Neto. Rio de Janeiro: José Olympio, 2008.

61 "É gênero difícil, a despeito de sua aparente facilidade, e creio que essa mesma aparência lhe faz mal, afastando-se dele os escritores, e não lhe dando, penso eu, o público toda a atenção de que ele é muitas vezes credor". Op. cit., p.115.

${ }^{62}$ Idem.

63 Antônio Cândido nos dá uma visão mais ampliada sobre a crítica do período. A visão não é mais promissora que a de Machado, mas ainda assim realça escritos de qualidade no período: "Se procurarmos uma crítica viva, empenhando a personalidade do autor e revelando preocupação literária mais exigente, só a encontraremos em alguns poucos ensaios, prefácios, artigos, polêmicas, na maioria incursões ocasionais de escritores orientados para outros gêneros". O único nome que cita como uma vocação mais forte para a
} 
desenvolvimento da literatura estaria ligada a uma espécie de missão pedagógica, no sentido de que se colocasse na vanguarda de uma evolução literária, elevando, pela teoria e análise, o nível das práticas escriturais. O trecho do artigo ratifica a própria atitude de Machado em relação à obra literária, mais fruto do estudo do que do gênio. Na advertência que escreveu para seu primeiro romance, Ressurreição, publicado em 1872, no ano anterior ao artigo "Instinto de Nacionalidade", Machado, num determinado momento, contrapõe o autor de gênio ao autor mediano (“de aptidões médias"), classificação na qual se encaixaria, sem necessariamente uma conotação depreciativa no julgamento. Se ao primeiro cabe a audácia e o ímpeto juvenil, características certamente românticas, ao segundo cabe uma confiança justa e ponderada e uma maior capacidade de reflexão, as duas aliadas à passagem dos anos. Machado, que já havia passado dos 30, se coloca aí (“Eu cheguei já a esse tempo") e escreve:

Com o tempo, adquire a reflexão o seu império, e eu incluo no tempo a condição do estudo, sem o qual o espírito fica em perpétua infância. ${ }^{64}$

O "estudo" é o ponto central, ou seja, Machado chama atenção para a necessidade de o escritor ser um homem que estuda o próprio objeto de trabalho, para o estabelecimento de um projeto consciente de obra. Há, por outro lado, talvez, uma reprimenda velada aos intelectuais da época, que pouco ou nada se dedicavam a um estudo aprofundado das formas e fazeres literários, se ficarmos só no âmbito do artigo, permanecendo numa certa indigência analítica, sem jamais saírem da "perpétua infância" intelectual, a que se refere Machado. O diletantismo, já aludido no primeiro capítulo, reforçado pela análise de Antônio Cândido ${ }^{65}$ para os críticos do período, nos permite a inferência de que, ao, de certa forma, lamentar a situação da crítica brasileira, estivesse também chamando a atenção dos próprios escritores para uma postura diferenciada em relação ao fazer e à tradição literária. No artigo de 73 , embora trate o conto em poucas linhas, há de se reparar que Machado talvez esteja sugerindo a seus contemporâneos uma consciência do gênero que até então não se fizera presente e que, sem ela, viesse a acarretar uma extrema dificuldade para que o conto atingisse um patamar artístico que satisfizesse o gosto do público, mas, principalmente, que provocasse o potencial criativo dos escritores.

crítica será o de Macedo Soares, que, no entanto, não perdurou. Para Cândido, os artigos de Soares "nas revistas acadêmicas são muito bons, como forma e pensamento". Op. cit., p.317.

${ }^{64}$ ASSIS, Machado de. Ressurreição. 5. ed. São Paulo: Ática, 1977, p.12.

${ }^{65}$ Ver nota 62. 
Há um pouco mais a dizer do pequeno parágrafo sobre o conto que Machado nos dá em "Instinto de Nacionalidade". Se no segundo e último período do parágrafo ele lamenta o descaso do público e autores em relação ao gênero, no primeiro período, pouco comentado, Machado revela, a partir de seu ponto de vista, um aspecto do panorama do conto no Brasil em 1873, em que se destacam, em primeiro lugar, os autores estrangeiros que influenciavam nossas letras naquele momento (Henri Murger, Trueba e Charles Dickens), e, em segundo lugar, a pouca expressividade dos contos até então publicados ("têm havido tentativas mais ou menos felizes"66), com a citação de apenas um nome, o de Luís Guimarães Júnior. Nesse artigo, Machado não cita outros autores românticos.

Em relação ao primeiro ponto, os autores estrangeiros, vejamos. $\mathrm{O}$ primeiro, o francês Henri Murger ${ }^{67}$ (1822-1861), cuja principal obra é Scènes de la vie de bohème ${ }^{68}$, publicada em Paris em 1851 e que depois inspirou a ópera de G. Puccini, La Bohème, não é considerado um contista. Seu livro mais conhecido é uma mistura de episódios sem aparente conexão, apenas ligados pelo tema geral da obra, a vida boêmia. Em janeiro de 1861, os irmãos Goncourt relatam a morte de Murger, frisando que ela possui 'l'air d'un mort de l'Écriture", simbolizando a morte da boemia ("cela me semble la mort de la bohème, cette mort par la décomposition [...]"69). A popularidade dessas histórias, tanto dentro da França quanto fora dela, foi intensa por toda a segunda metade do século XIX, visto ter sido transformada em ópera não apenas por Puccini, em 1896, mas também por Ruggero Leoncavallo em 1897 (La bohéme), além de ter sido transformada em peça de teatro em $1849^{70}$, antes mesmo da compilação das histórias em livro, em 1851. A referência de Machado, que é de 1873, confirma sua popularidade também aqui ${ }^{71}$, como inspiração para os autores nacionais, que escreviam “à maneira de...” Murger, talvez implicando, no que a expressão pode sugerir, uma depreciação de uma escrita imitativa e pouco crítica. Além disso, em Murger, pode-se pensar que o tom boêmio da fonte mais a forma indecisa entre romance e reunião de contos que apresenta não incentivariam os

\footnotetext{
${ }^{66}$ ASSIS, 2008, p.115.

67 Para informações sobre a obra e a vida de Henri Murger, ver NEAL, Dyana. "The Bohemian life according to Henri Murger (1822-1861)". http://www.wbjc.com/the-bohemian-life/ . Também em http://www.universalis.fr/encyclopedie/henri-murger/.

${ }^{68}$ As histórias foram publicadas de forma independente umas das outras nas páginas do Le Corsaire, de Paris, a partir de março de 1845 até 1849.

${ }^{69}$ Journal des Goncourt, 28 janvier, 1861. Acessível em http://www.apophtegme.com/ALBUM/goncourtmurger.htm

${ }^{70}$ La vie de la bohème, adaptação de Theodore Barrière e Henri Murger, 1849.

${ }^{71}$ Lembremos que Félix, protagonista de Ressurreição, resolve encerrar um de seus amores após a leitura do livro de Murger.
} 
autores nacionais a um trabalho mais depurado de criação. Por outro lado, talvez possamos entender que, se a forma parece híbrida por inabilidade autoral, no sentido de não ter conseguido encaixar os episódios dentro de um processo lógico e romanesco, também sugere uma impureza do gênero, de forma que, mesmo sem uma intencionalidade satírica que ocasione a mistura com propósitos cômicos, a ideia de pureza se vê em xeque.

O segundo autor, provavelmente, é o espanhol Antonio de Trueba ${ }^{72}$ (1819-1889), poeta e romancista, mas também contista de um estilo que se pode chamar de regionalista, em que retratava uma Espanha campesina, com especial ênfase nostálgica a uma vida rural idealizada e romantizada em oposição a uma crescente urbanização de um país europeu em desenvolvimento no século XIX. Trueba é também conhecido como folclorista, no sentido de trazer a um público letrado e urbano as histórias que viviam entre os camponeses, de sabor às vezes ingênuo e sentimental, e outras, pitoresco. Também "à maneira de" Trueba, os autores nacionais, em 1873, vinham procurando retratar a vida além dos quarteirões urbanos, com matizes pitorescas e sentimentais, como talvez sugira a análise de Machado $^{73}$. Se considerarmos que a escolha do tema não é o que determina a qualidade artística da obra, há de se relevar que, de certo modo, o regionalismo, mesmo em sua fase romântica, se ateve demais a um realismo imitativo e superficial ${ }^{74}$, em que não problematizava seu próprio objeto, dando pouca ênfase, dessa forma, a uma expressão artística mais elevada.

O terceiro autor, o conhecidíssimo Charles Dickens, provavelmente circulava no Brasil havia algum tempo, em originais ingleses ou traduções francesas, que abrangiam seus romances e muitos de seus $\operatorname{contos}^{75}$. Só Machado de Assis possuía em sua biblioteca

\footnotetext{
${ }^{72}$ Ver http://www.biografiasyvidas.com/biografia/t/trueba_antonio.htm .

${ }^{73}$ Bernardo Guimarães já havia publicado histórias nesse sentido em Lendas e romances (1871) e Histórias e tradições da província de Minas Gerais (1872).

${ }^{74}$ James Wood lembra um elemento importante da Poética de Aristóteles que cabe aqui inserir para melhor localizar a questão do realismo "imitativo e superficial". Diz Wood, no capítulo em que trata sobre as convenções do realismo: "Se reexaminarmos a formulação original de Aristóteles sobre a mimese, na Poética, veremos que ele não trata da referência. A história, diz Aristóteles, nos mostra 'o que Alcibíades fez'; a poesia - isto é, a narrativa de ficção - nos mostra 'o tipo de coisa que podia acontecer' a Alcibíades. Aqui, a ideia importante e subestimada é a plausibilidade hipotética - a probabilidade: a probabilidade envolve a defesa da imaginação crível contra o incrível. Decerto é por isso que Aristóteles escreve que uma impossibilidade convincente na mimese é sempre preferível a uma possibilidade inconvincente. O peso recai imediatamente não sobre a simples verossimilhança ou a referência (visto que Aristóteles reconhece que um artista pode representar algo que é fisicamente impossível), e sim sobre a persuasão mimética: a tarefa do artista é nos convencer de que aquilo podia ter acontecido. Assim, a plausibilidade e a coerência interna se tornam mais importantes do que a exatidão referencial. E essa tarefa, naturalmente, demandará um grande artifício ficcional, e não um mero registro informativo". WOOD, James. Como funciona a ficção. Trad. Denise Bottmann. São Paulo: Cosac Naify, 2012, p.191. Entendemos que os contistas românticos, por falha no "artifício ficcional", atolaram em diversas "possibilidades inconvincentes".

${ }^{75}$ Ver VASCONCELOS, Sandra Guardini T. "Romances ingleses em circulação no Brasil durante o século XIX". In.: www.unicamp.br/iel/memoria/Ensaios/Sandra/sandralev.htm . Acessado em 12/09/16.
} 
mais volumes de Dickens do que de Shakespeare (31 títulos do primeiro, 20 do segundo $)^{76}$. Aliás, o próprio Machado traduziu Dickens para o português ${ }^{77}$. Lembremos que as histórias de Dickens possuem um estilo fortemente melodramático, com enredos recheados de peripécias e reviravoltas e que, embora tenha criado personagens marcantes, como Scrooge, de A Christmas Cool, ou o próprio Oliver Twist, do romance de mesmo nome, é criticado muitas vezes pela inverossimilhança de eventos ou por um sentimentalismo pouco realista, mais voltado ao embevecimento de seu público, por sinal bastante fiel ${ }^{78}$. É possível que Machado estivesse já compreendendo a artificialidade de um enredo em que ações e personagens se revestem de um caráter inverossímil, o que viria a ser a pedra de toque de sua crítica a Eça de Queiroz, anos depois ${ }^{79}$. Não apenas por Dickens, evidentemente, mas a contaminação melodramática, o sentimentalismo e a proliferação das peripécias na trama poderiam estar sendo vistas como uma espécie de mal da prosa brasileira no período romântico, com boa contribuição do teatro que se fazia no Brasil. Machado habilmente retrataria esse aspecto no conto "A chinela turca", publicado pela primeira vez em 1875, depois recolhido no volume de Papéis avulsos, com ligeiras modificações, em 1882.

Ora, se tentarmos resumir o que estaria implícito na visão de Machado sobre o conto brasileiro em 1873, em virtude dos modelos estrangeiros aos quais se refere, considerando o aspecto imitativo presente em nossos escritores a que alude com a expressão “à maneira de", podemos perceber:

a) uma indecisão da forma: o conto não parece ter ainda atingido uma plenitude formal, estando mais voltado ora para a novela, ora para a lenda popular, provavelmente resultado de um desconhecimento mais apurado de nossos escritores sobre as características intrínsecas do gênero;

b) um foco na construção das peripécias: a trama é supervalorizada, sem o necessário respaldo da verossimilhança, que, por necessidade de suprir o excesso de ações dinâmicas, torna-se superficial;

\footnotetext{
76 VIANNA, Glória. "Revendo a biblioteca de Machado de Assis". In.: JOBIM, José Luís (Org.). A biblioteca de Machado de Assis. Rio de Janeiro: Topbooks, 2001, p. 99.

${ }^{77}$ Sabemos que sua tradução de Oliver Twist, feita a partir do francês, ficou incompleta, e foi publicada no Jornal da Tarde, do Rio de Janeiro, entre 23 de abril e 23 de agosto de 1870. Também conforme MASSA, Jean-Michel. Dispersos de Machado de Assis. Rio de Janeiro: MEC/INL, 1965, p.529-554.

${ }^{78}$ Afirma Karin Volobuef em nota que "o romancista esmerou-se, pois, em ser realista no tocante ao retrato dos problemas sociais (suscitados pela iniquidade e miséria, que campeavam por Londres no século XIX), no que se refere, porém, à construção do personagem, preferiu desenvolver qualidades com chances de cativar a atenção do leitor. E, uma vez garantida a simpatia do público, o enredo se encarregaria de familiarizá-lo com os problemas que Dickens procurava denunciar”. Op. cit., p.176.

${ }^{79}$ ASSIS, Machado de. "O primo Basílio". O Cruzeiro, Rio de Janeiro, 16 e 30 de abril de 1878.
} 
c) um sentimentalismo exacerbado: evidente que era um elemento de época, ainda romântica, mas que de certa forma produzia uma inconsistência na história, em especial na motivação das personagens, que não eram abordadas de forma mais profunda;

d) uma tipologia e um apelo à caricatura: situações e personagens parecem reproduzir-se, como tipos e modelos, sem uma criação artística original, de modo que a repetição dos mesmos elementos cria uma certa monotonia no conjunto das histórias.

Se, de fato, Machado expõe essa crítica ao conto não só considerando seus contemporâneos, mas provavelmente sua própria obra como contista ${ }^{80}$, cabe perceber a que nível de consciência crítica sobre o gênero ele atingia naquele momento. Já um contista experiente em 1873, Machado demonstra que ainda havia algo fundamental a ser alcançado pelos escritores para que o conto atingisse o nível de excelência artística de que era merecedor, adquirindo o mesmo respeito e admiração que, naquele momento, se voltavam ao romance e à poesia, apesar das contradições que Machado talvez já estivesse percebendo, em especial no romance, como demonstraria o artigo contra Eça de Queiroz em 1878. Lembremo-nos, por exemplo, como vimos no capítulo anterior, o que Machado escreve em "Frei Simão", uma das narrativas de Contos Fluminenses, quando atribui as palavras abaixo a uma de suas personagens, em que o pai do moço apaixonado escreve uma carta ao amigo Amaral solicitando ajuda:

Retenham-o (sic) por lá como puder. O pretexto da viagem é ter eu necessidade de ultimar alguns negócios com você, o que dirá ao pequeno, fazendo-lhe sempre crer que a demora é pouca ou nenhuma. Você, que teve na sua adolescência a triste ideia de engendrar romances, vá inventando circunstâncias e ocorrências imprevistas, de modo que o rapaz não me torne cá antes de segunda ordem. [...] (grifo nosso) ${ }^{81}$

Se o alvo da graça é o amigo, evidentemente o da sátira não é. Já em 1864, ano de publicação do conto no Jornal das Famílias, Machado dispunha de um olhar crítico para o que se praticava em literatura no Brasil ${ }^{82}$. O verbo "engendrar" tem, entre seus significados, o de gerar, criar do nada, inventar. Parece claro que "engendrar romances" é só um divertido lance de imaginação de Amaral, e que não envolveria perigo maior, já que elaborado na juventude. Felizmente, o amigo largara a "triste ideia" e tornara-se

\footnotetext{
${ }^{80}$ Lembremos que o volume Contos fluminenses, é de 1869, e, ainda em 1873, Machado editaria as Histórias da meia-noite.

${ }^{81}$ ASSIS, Machado de. Contos fluminenses. Edição preparada por Marta de Senna. São Paulo: Martins Fontes, 2006, p.292.

${ }^{82}$ Exemplos importantes a favor de meu argumento são dois artigos críticos de Machado publicados nessa época. Refiro-me a "O passado, o presente e o futuro da literatura", publicado em A Marmota, nos dias 9 e 23 de abril de 1858, quando o autor contava apenas 19 anos, e "O ideal do crítico", publicado no Diário do Rio de Janeiro, a 8 de outubro de 1865.
} 
comerciante. No entanto, a veia imaginativa não se perde e, portanto, seria fácil ao amigo que fosse "inventando circunstâncias e ocorrências imprevistas" para enganar o rapaz, assim como o romancista fazia para entreter o leitor. $\mathrm{O}$ modelo parece arraigado na própria formação cultural do homem letrado brasileiro, embebido desde o advento da imprensa numa formação romântica, educado em peripécias e reviravoltas, e que, mesmo não seguindo as carreiras das letras, mantinha intacta sua pitoresca alma imaginativa. $\mathrm{O}$ Machado de 73 não parece ter visto grande mudança na literatura brasileira desde então e seu diagnóstico do conto não é nada promissor, considerando o desmazelo analítico da época e o lugar a que pertencia. A cultura literária brasileira de então era forjada sobre uma base romântica, importada, como sabemos, mas de forma nacionalista e regionalista, em que a qualidade melodramática prevalecia, talvez resultado da contaminação da educação teatral que a acompanhava, como já afirmamos.

Retomemos ainda o artigo de Machado, pois além das três influências estrangeiras que apontam para o conto e que soam, possivelmente, de modo negativo, ele faz uma ressalva entre os escritores brasileiros, citando o nome de Luís Guimarães Junior, "folhetinista elegante e jovial"83. Além de poeta e dramaturgo, Guimarães Júnior também escrevia romances e contos. Na década de 70 havia lançado em prosa - no momento em que Machado escreve - dois livros: Contos sem pretensão, de 1872, que trazia três longos contos, e Histórias para gente alegre, 1870, que trazia dois textos, dentre os quais a novela satírica "A família Agulha", que havia sido publicada em folhetim no mesmo ano de lançamento do volume ${ }^{84}$. Considerando a adjetivação que Machado utiliza para classificar o estilo folhetinesco de Guimarães Júnior, é de supor que estivesse especialmente falando do romance-novela "A família Agulha”. Com esquema semelhante às Memórias de um sargento de milícias (1854), de Manuel Antônio de Almeida, o folhetim humorístico de Guimarães Júnior pretende contar a história da família Agulha, em especial de Bernardino Agulha, filho de Anastácio Temporal Agulha e dona Eufrásia Sistema, por quem o patriarca Anastácio se apaixonara, apesar de sua pobreza e feiura. Além dessas irresistíveis qualidades, o que de fato selara o amor de Anastácio por Eufrásia teriam sido seus enormes pés, número $47^{85}$. O folhetim se desdobrará em 36

\footnotetext{
${ }^{83}$ ASSIS, 2008, p.115.

${ }^{84}$ Os folhetins saíram no Diário do Rio de Janeiro. Wilson Martins a classifica duplamente como novela picaresca e romance de costumes. In.: "Clássicos do humorismo". O Globo Online, 21/02/2004. www.jornaldepoesia.jor.br/wilsonmartins126.html Acessado em 10/09/2016.

${ }^{85} \mathrm{O}$ trecho merece citação: "Eufrásia, filha quase legítima de Lucas Pereira Sistema e de D. Senhorinha Sistema, era uma moça magra, fina, estreita como o esqueleto de um chapéu-de-sol inglês. A natureza não fora pródiga de encantos para a filha única de Lucas Sistema. Dera-lhe uma cabeça insignificante, um
} 
capítulos, de acentuado tom satírico, mas cada um deles com uma relativa independência em relação aos outros, ou seja, é possível ler cada episódio solto com o mesmo prazer e graça com que se lê todo o romance, possivelmente efeito da própria forma do folhetim. Não por acaso, Machado já nos indica aqui, em 1873, sua árvore genealógica literária, que viria a ser fartamente explorada pela crítica mais recente, que contempla sua vocação humorística $^{86}$.

Em suma, o pequeno parágrafo sobre o conto que Machado escreve em "Instinto de Nacionalidade" tem mais a revelar do que propriamente a esconder, no sentido de que nos mostra um escritor bastante atento ao que se fazia em literatura no Brasil, com olhar perspicaz de conjunto, em que observa a epigonia e pouca originalidade da produção brasileira no gênero conto, mas também um olhar agudo, que fisga no mar de produções "mais ou menos felizes" algumas pérolas. Por outro lado, podemos ainda ver que Machado, autor consciente, sabe do que deve fugir, embora ainda não tenha encontrado satisfatoriamente seu caminho, ainda que já o tenha vislumbrado na escrita satírica de Guimarães Júnior. Se Guimarães não seria o seu mestre, ainda assim ele mostrava o quão produtivo e expressivo podia se tornar o humor na obra literária, fator que Machado aprimoraria ao longo da década de 70 para não mais largar.

A minúscula referência de Machado ao conto no Brasil corrobora o que a unanimidade da crítica vem afirmando sobre o gênero: o de que antes do Machado de Papéis avulsos não existiu conto de qualidade no Brasil. O autor carioca teria inaugurado a forma artística do conto, não sua forma histórica, que remeteria a um obscuro Joaquim

pescoço de milha e meia e um par de pés que podiam servir de pedestal a ela, à família toda, e a algumas tribos mais! Que pés! Onde caíssem era achatação certa!

Eis aí o que são gostos e contrastes no mundo! Foi justamente por causa dos pés que Anastácio se apaixonou por ela. Quando nas vésperas do noivado lhe ponderaram os amigos os inconvenientes que sobreviriam do seu casamento com uma moça pobre e feia como era Eufrásia, Anastácio Agulha exclamou estalando a língua de prazer:

- Ela calça 47, Suzer!”. A família Agulha, cap. 1. GUIMARÃES JR., Luís. A família Agulha: romance humorístico. Organização, edição e notas de Flora Sussekind. $3^{\mathrm{a}}$ ed. Rio de Janeiro: Vieira \& Lent: Fundação Casa de Rui Barbosa, 2003, p.38.

${ }^{86}$ Em "Figurações do autor e narração excêntrica em Nodier e Guimarães Júnior", Ilana Heineberg filia a novela de Guimarães, chamando-a de "excêntrica", à tradição que vem de Luciano, passa por Rabelais e Cervantes, e chega a Sterne, Xavier de Maistre, Nerval, Gautier e Charles Nodier. Não faz referência a Machado de Assis, mas, sabemos que essa mesma tradição fará escola para as interpretações do romance de Machado de Assis a partir das Memórias póstumas de Brás Cubas, hipótese levantada pela primeira vez por José Guilherme Merquior em "Gênero e estilo das Memórias póstumas", ensaio de 1972, depois aprofundado por outros autores, como Enylton de Sá Rego e Valentim Faccioli. Ver HEINEBERG, Ilana. "Figurações do autor e narração excêntrica em Nodier e Guimarães Júnior". In.: Navegações, v.1, n.1, p.4149, março de 2008. revistaseletronicas.pucrs.br/ojs/índex.php/navegações/article/viewFile/3683/2833 Acessado em 14/09/2016. 
Norberto, em 1841. Certamente plausível, considerando o ponto de vista adotado pelos críticos, o da qualidade estética, a sentença chama atenção por alguns aspectos:

a) o país possuía prosadores respeitados e de relativo talento antes de Machado, como José de Alencar, Taunay, Bernardo Guimarães ou Manuel Antonio de Almeida, os quais pouco ou nada se aventuraram no gênero;

b) a prática da história curta não era uma novidade entre nossos escritores anteriores a 1880, se considerarmos que muitas crônicas publicadas em jornais por diversos autores, inclusive Machado, tinham decidido caráter narrativo ${ }^{87}$;

c) a valoração estética produziu um hiato crítico para o período ${ }^{88}$, por não se aprofundar na análise do conto dito romântico, esquadrinhando suas características e influências e, até, apontando seus principais defeitos, com o intuito de entender como o gênero deu um salto qualitativo na década de 1880 através, primeiramente, da pena de Machado, mas depois, de outros autores, como Raul Pompeia e Lúcio de Mendonça.

Esse hiato tornou difícil a tarefa de analisar a evolução do conto no Brasil não somente no sentido de redefinir a avaliação crítica que se faz dos primórdios do gênero aqui, em geral, negativa, mas de observar, dentro da própria história do conto no país, que a explosão de Papéis avulsos em 1882, enquanto exemplo de reunião de textos amadurecidos formal e esteticamente, possa não ter sido obra de um milagre ou reviravolta machadiana, como já apontado em relação aos romances ${ }^{89}$. Se Roberto Schwarz percebe no romance uma evolução da forma ao mesmo tempo em que o conteúdo se dialetiza, reiterando a importância dos primeiros livros machadianos para o desenvolvimento da forma em Memórias póstumas de Brás Cubas ${ }^{90}$, aqui se pretende examinar os elementos que possibilitam distinguir uma linha menos descontínua para o conto no Brasil. Alguns críticos ${ }^{91}$ elevam Machado ao cume da criação no conto, como

\footnotetext{
${ }^{87}$ Veja-se, como exemplo, os textos publicados por Machado em O Cruzeiro, em 1878. Penso em "Filosofia de um par de botas, "Um cão de lata ao rabo" e "Elogio da vaidade", todos de caráter eminentemente narrativo. Também José de Alencar, nas crônicas de Ao correr da pena, exercitou essa possibilidade de narrativa curta.

${ }^{88}$ Volobuef chama atenção para a dificuldade hoje existente de rastrear essa produção com vistas a uma compreensão mais abrangente do período, uma vez que boa parte desses contos foi publicado apenas em periódicos, hoje de difícil acesso, ou porque foram perdidos, ou porque não apresentam condições de leitura. Op. cit., p.199.

${ }^{89}$ SCHWARZ, Roberto. “A viravolta machadiana". Novos estudos, CEBRAP, n.69, julho de 2004, p.1534.

${ }^{90}$ SCHWARZ, Roberto. "A novidade das Memórias póstumas de Brás Cubas". In.: Machado de Assis: uma revisão. Org. de Antônio Carlos Secchin, José Maurício Gomes de Almeida e Ronaldes de Melo e Souza. Rio de Janeiro: In-Fólio, 1998, p.47-64.

${ }^{91}$ Sobre a importância capital de Machado na história do conto no Brasil, ver CAVALHEIRO, Edgard. Evolução do conto brasileiro. Rio de Janeiro: MEC, 1954; GOMES, Eugênio. "Evolução do conto". In: COUTINHO, Afrânio (org.). A literatura no Brasil. Vol. VI. Rio de Janeiro: Editorial Sul Americana, 1955;
} 
se ele tivesse alcançado o topo num único salto. Todos os contistas anteriores não teriam chegado ao sopé da montanha. Creio que as análises feitas do romance machadiano tornam essa imagem inverossímil. Se concordarmos com Lúcia Miguel Pereira que Machado foi melhor contista que romancista ${ }^{92}$, diferente de todos os seus contemporâneos, que se destacaram mais em outros gêneros, nem por isso se pode afirmar que a contística machadiana surgiu do nada para o mais alto posto da criação, ao lado de contemporâneos estrangeiros, como Anton Tchekhov e Guy de Maupassant. Que chegou lá, não há dúvida, mas a subida foi menos íngreme, porque, de alguma maneira, a capacidade crítica de Machado foi a corda que auxiliou a escalada, permitindo-lhe vislumbrar no percurso, em breves pausas, um detalhe de beleza na paisagem. Explicome: Machado foi um amante da literatura, à qual se dedicava não apenas ao produzi-la, mas também ao lê-la e analisá-la. Se, por um lado, sua produção crítica não é tão extensa, por outro mostra grande sensibilidade estética e analítica, ao mesmo tempo que, afora seu gosto pelos clássicos, demonstra enorme interesse pela literatura produzida por seus contemporâneos $^{93}$. Era leitor voraz e curioso, como atestam sua biblioteca e suas referências, e essa forma de leitura aliada a uma autoconsciência literária extraordinária é que nos permite afirmar que Machado, também em relação ao conto, foi tateando formas para chegar ao máximo de sua criação e que esse tatear foi balizado pela leitura atenta do que era produzido no gênero em sua época.

Peguemos um exemplo.

GRIECO, Agrippino. Evolução da prosa brasileira. Rio de Janeiro: Ariel, 1933; LIMA, Herman. “O conto, do realismo aos nosso dias". In: A literatura no Brasil. Vol.II. Organização de Afrânio Coutinho. Rio de Janeiro: Editorial Sul Americana, 1955; e LIMA, Herman. Variações sobre o conto. Rio de Janeiro: Ministério da Educação e Saúde, 1952. Coleção Cadernos de Cultura, número 37.

92 A citação não é literal, mas em seu estudo sobre o autor, no capítulo "O artista", Pereira, entre várias comparações entre romance e conto desfavoráveis ao romance, conclui: "Há, porém, algumas linhas mestras da sua obra que só nos contos se precisam". PEREIRA, Lúcia Miguel. Machado de Assis: estudo crítico e biográfico. 6.ed. Belo Horizonte: Itatiaia; São Paulo: Editora da Universidade de São Paulo, 1988, p.227.

${ }^{93}$ Creio que não se deve esquecer a lição de Antônio Cândido, que ao tratar do romance de Machado de Assis, alude a uma característica que se manifesta em outros aspectos da sua obra: "Se voltarmos porém as vistas para Machado de Assis, veremos que esse mestre admirável se embebeu meticulosamente da obra dos predecessores. A sua linha evolutiva mostra o escritor altamente consciente, que compreendeu o que havia de certo, de definitivo, na orientação de Macedo para a descrição de costumes, no realismo sadio e colorido de Manuel Antônio, na vocação analítica de José de Alencar. Ele pressupõe a essência dos predecessores, e esta é uma das razões da sua grandeza: numa literatura em que, a cada geração, os melhores começam da capo e só os medíocres continuam o passado, ele aplicou o seu gênio em assimilar, aprofundar, fecundar o legado positivo das experiências anteriores. Este é o segredo da sua independência em relação aos contemporâneos europeus, do seu alheamento às modas literárias de Portugal e França. Esta, a razão de não terem muitos críticos sabido onde classificá-lo". In.: Formação da literatura brasileira: momentos decisivos. Vol. 2. $9^{\text {a }}$ ed. Belo Horizonte: Itatiaia, 2000, p.104. 
Em resenha publicada na Semana Ilustrada de 30 de janeiro de $1870^{94}$, sob o pseudônimo de M. ${ }^{95}$, Machado dá notícia do livro de um poeta maranhense chamado Flávio Reimar. O título do livro é Entre o céu e a terra, publicado em 1869. Também informa na resenha que Flávio Reimar é o pseudônimo de Gentil Homem de Almeida Braga. Sobre o livro, explica Machado:

Entre o céu e a terra é o título de um livro em prosa que Flávio Reimar me enviou do Maranhão. Ele lá explica no prólogo a razão deste título, que lhe não parece congruente com o livro. Eu creio que o é, se lhe procurarmos a razão do título, não na letra, mas no espírito da obra. Aqueles escritos diversos, reunidos caprichosamente num volume, não são bem do céu nem bem da terra, posto falem da terra e do céu, - de cousas alegres ou cousas tristes, de filosofia, saudade, de lágrimas e sorrisos, - evocações do passado e arroubos de imaginação, episódios e fantasias, descrições e devaneios, cousas cá de baixo e cousas lá de cima. O título exprime bem a unidade do livro no meio da diversidade de assuntos ${ }^{96}$.

A descrição de Machado aponta para algo semelhante ao que depois diria em "Instinto de nacionalidade": não há uma forma definida para o conjunto das narrativas agrupadas por Flávio Reimar, pseudônimo de Almeida Braga. O livro se divide em quatro partes: "Reminiscências de um transmigrado", espécie de livro de memórias de uma alma

\footnotetext{
94 Acessível em http://memoria.bn.br/DocReader/Hotpage/HotpageBN.aspx bib=702951\&pagfis=3870\&pesq=\&url=http: //memoria.bn.br/docreader\#

95 “Com esta inicial estão subscritos alguns trabalhos na Semana Ilustrada (Rio, em diversas épocas, entre 1862 e 1874).

A seguinte carta de Joaquim Serra a Machado de Assis, s.d., documenta a nossa afirmativa:

'Machado de Assis,

Aí fica o livro do Gentil; é uma linda cousa!

Escreve sobre ele; lembra-te que estás em falta para com o Gentil (que é teu amigo) desde a publicação da Eloá!

Esse livro tem grande merecimento; as paginas intituladas O Caçador de Pacas; Carlotinha da Mangueira, e Singela recordação, são inimitáveis. Tudo o mais é bom e pede um bom artigo.

Escreve-o na próxima semana, como fizeste com os Corimbos.

E as Falenas?

Vai conversar na Reforma.

$\mathrm{O}$ am. ${ }^{\circ}$

Serra.'

(cf. Ver. Acad. Bras.,n.5,julho de 1911, p.69).

De fato, aquela referência 'como fizeste com os Corimbos' diz respeito ao trabalho "Um Poeta Fluminense Carymbos" que figura subscrito por M., no n. 473 da Semana Ilustrada (2-1-1870).

Mais tarde, a 30/1/1870, n. 477 do mesmo periódico, encontramos a desincumbência do pedido de Joaquim Serra: "Um Poeta Entre o céu e a Terra, por Flavio Reimar", trabalho também subscrito por M.". In.: SOUZA, J. Galante de. Bibliografia de Machado de Assis. MEC, Instituto Nacional do Livro, Rio de Janeiro, 1955
}

http://www.machadodeassis.org.br/abl minisites/cgi/cgilua.exe/sys/start.htm?UserActiveTemplate=ma chadodeassis\&sid=90 Acessado em 24/09/2016.

\footnotetext{
${ }^{96}$ Semana Ilustrada, 30 de janeiro de 1870.
} 
errante, que atravessa os séculos encarnando em diferentes seres - homens, animais, vegetais, minerais - de veia satírica e cuja autonomia das partes é bem evidente; "Fantasias", crônicas, sendo algumas de teor narrativo; "Contos e pontos", dividida entre contos propriamente ditos, de curta extensão e digressões filosófico-satíricas como, por exemplo, "Se Voltaire fosse gordo e Theophilo Gautier fosse magro"; e, por fim, "Traços e meias tintas", divagações, perfis e descrições impressionistas. Vista a diversidade dos escritos, a unidade a que Machado se refere é a "unidade do estilo, que é característica dos escritores feitos". À primeira parte do livro, Machado chama de

obra de alegre fantasia e amena erudição, travada às vezes de tristeza, outras vezes (em mal!) de alusões políticas, ainda assim raras e despidas de azedume, porque os ares da poesia têm o condão de sacudir do espírito a poeira cá de baixo ${ }^{97}$.

Após o elogio, enumera alguns dos textos que o leitor não deveria deixar de ler, fazendo a ressalva de que "o livro todo merece ser lido, porque é bom". Diz ainda dos textos que o leitor encontrará "o riso franco, a jovialidade do estilo, o capricho da imaginação". Mais à frente acrescenta:

Eu bem quisera dizer alguma cousa desagradável ao poeta, mas o seu livro está por tal modo longe de regras e modelos, é obra tão pessoal e caprichosa, que a crítica só lhe pode exigir duas cousas: que seja interessante e tenha estilo. Preenche o poeta estas condições; não é possível exigir-se mais ${ }^{98}$.

À parte algumas aproximações que poderíamos fazer dessa resenha com as advertências de Machado inseridas em alguns de seus livros ${ }^{99}$, é de salientar que o trabalho de Almeida Braga lhe despertou a atenção para valores que lhe eram caros, mas que, pelo menos até aquele momento, em seus contos, ele não havia conquistado integralmente. Ressurreição, o primeiro romance, só sairia dois anos depois da publicação da resenha e estaria muito longe desse tom. Somente as crônicas que Machado, à época, publicava na Semana Ilustrada traziam um pouco desse tom satírico que seria sua marca

\footnotetext{
97 Idem.

${ }^{98}$ Ibidem.

${ }^{99}$ Lembremos de como Machado trata o binômio diversidade-unidade em Papéis avulsos: “Avulsos são eles, mas não vieram para aqui como passageiros, que acertam de entrar na mesma hospedaria. São pessoas de uma só família, que a obrigação do pai fez sentar à mesma mesa". ASSIS, Machado de. Papéis avulsos. Edição preparada por Ivan Teixeira. São Paulo: Martins Fontes, 2005. Ou a união de alegria e tristeza na advertência de Memórias póstumas de Brás Cubas: "Trata-se, na verdade, de uma obra difusa, na qual eu, Brás Cubas, se adotei a forma livre de um Sterne, ou de um Xavier de Maistre, não sei se lhe meti algumas rabugens de pessimismo. Pode ser. Obra de finado. Escrevi-a com a pena da galhofa e a tinta da melancolia, e não é difícil antever o que poderá sair desse conúbio". ASSIS, Machado de. Memórias póstumas de Brás Cubas. São Paulo: Penguin Classics/Companhia das Letras, 2014. Ambas as obras, marcos de um Machado maduro.
} 
principal $^{100}$. A admiração pelo livro de Almeida Braga, portanto, não parecia ser jogo de cena ou mera troca de favor ${ }^{101}$, e sim uma identificação com aspectos da escrita que Machado cada vez mais passava a admirar e, posteriormente, a praticar.

O livro do autor maranhense, de fato, possui características que extrapolam o ambiente romântico em que foi publicado. Embora utilize algumas premissas românticas, como o retrato da inocência e da infância, a fuga do presente como escapismo dos problemas, a vaguidão e a melancolia dos ambientes e personagens descritos, tudo é feito com outra tonalidade, com matizes realistas e, portanto, desmistificadores de uma concepção romântica, e satíricos, em que desde o início se quebra a expectativa dos bons sentimentos e de uma verossimilhança presa aos seus referentes. Há de se notar, ainda, um caráter fantástico em algumas narrativas, principalmente em toda a primeira parte, as "Reminiscências de um transmigrado", e que será um tipo de narrativa à qual Machado se apegará bastante, ou seja, a criação de argumentos absurdos como alegorias da sociedade brasileira ${ }^{102}$. Vejamos um trecho dessas reminiscências. Na décima parte, intitulada "Real vitória", o narrador abre a história:

$\mathrm{Na}$ extensa escala das transmutações da minha vida um dos períodos, que ainda hoje mais me iluminam a imaginação e perfumam a sensibilidade, é o da minha existência de irupê. Os aborígenes do extenso país, que demora além do Orinoco, e que é conhecido com o nome de Guiana Inglesa, dão a denominação de irupê à maior maravilha da flora universal, à flor, que os navegantes ingleses por atenção e honra a sua rainha começaram a chamar de real Victória.

Eu fui uma irupê, e existi ao tempo em que Moisés se educava no Egito entre as arcadas do palácio do Faraó reinante. Fundamento a hipótese no fato de se haver tido conhecimento do modo como escapou milagrosamente o grande legislador do povo hebreu ao decreto exterminador do rei Herodes na corte do monarca constitucional de Essequebo ${ }^{103}$, minha pátria então. A notícia foi trazida por um sábio viajante daquela época, o qual pode ser considerado o

\footnotetext{
${ }^{100}$ Ver GLEDSON, John. "Introdução". In.: Machado de Assis: crônicas escolhidas. Seleção, introdução e notas de John Gledson. São Paulo: Penguin Classics Companhia das Letras, 2013, p.14. Para que a afirmação não soe categórica, podemos entrever um Machado humorístico em contos como "O país das quimeras", publicado em $O$ Futuro, em novembro de 1862. No entanto, aqui ele está bem mais próximo do conto fantástico que do satírico, em que pese uma certa ironia romântica na figura do poeta apaixonado do conto. Repare-se, por exemplo, com que diferença um tema parecido será tratado por Raul Pompeia em "Como nasceu, viveu e morreu minha inspiração", conto publicado em A Comédia, em 1881. Também para o fantástico em Machado ver OLIVEIRA, Aline Sobreira de. A medalha e seu reverso: fantástico e desfantasticização em contos de Machado de Assis. Dissertação de mestrado. Belo Horizonte: UFMG, 2012.

${ }^{101}$ Como sugere a carta de Joaquim Serra a Machado de Assis. Ver nota 94.

${ }^{102}$ Veja-se, por exemplo, o devaneio absurdo do bacharel Duarte em "A chinela turca", ou a ambientação temporal e os argumentos de "Na arca", "O segredo do bonzo", "A sereníssima república", "O espelho" e "Uma visita de Alcibíades", fora a lógica irreal de Simão Bacamarte em "O alienista", todos em Papéis avulsos. Ou, já menos frequente, em Histórias sem data, os contos "A igreja do diabo", "Conto alexandrino", "A segunda vida" e "As academias de Sião".

${ }^{103} \mathrm{Ou}$ Essequibo, região da Guiana Holandesa.
} 
patriarca da tribo dos Humboldts modernos, e que teve a fortuna de percorrer ambos os continentes americanos, vindo, pelo estreito de Behring. ${ }^{104}$

Esse início, concordando-se com Machado que possui bom estilo, apresenta a premissa para a história que virá adiante. $\mathrm{O}$ narrador transmigrou sua alma para uma vitória-régia, a tão conhecida flor amazônica, em um tempo histórico remoto e não definido. O “conto", pode-se dizer assim, vai então narrar a vida dessa irupê no reino de Essequebo. Após situar o leitor, o narrador fará uma longa e bela descrição naturalista de sua vida como planta, que surpreende não só pelo detalhismo, mas também pela carga de sensações, até mesmo eróticas, que apresenta. Após essa descrição, o narrador nos coloca no salão principal do palácio, ao qual enfeita, e onde o primeiro ministro do rei faz um discurso em que tenta convencer o monarca a aumentar os impostos. Do ministro, diz o narrador que

era um homem desbarbado e muito conhecido no país por amor de umas frases infelizes de que fez uso no Parlamento à semelhança do célebre dito: reina $a$ paz em Varsóvia - que tamanha voga dará a certo ministro francês no reinado de Luís Filipe ${ }^{105}$.

Após o discurso e a concordância do rei, o narrador, aliado a outras vitórias-régias, planeja para o dia seguinte uma rebelião contra o aumento de impostos. $\mathrm{O}$ absurdo da situação se amplia com o fato de que uma revolta contra os impostos parta de um grupo de vitórias-régias, que por sua vez já tinham opinião sobre o assunto por terem ouvido antes algo semelhante dito por um grupo de patos bravos, que diziam que "o imposto era filho hermafrodita do diabo com os agentes do fisco"106. A sátira domina a história e o grotesco das situações se complica. Durante a revolução, o narrador atacará o conselho de ministros empunhando como arma um livro de versos de Longfellow, o irupê-líder das plantas revoltosas entrará armado com a bengala de cana da Índia roubada ao primeiroministro, e as demais revolucionárias vestidas com a armadura de seus próprios vasos. Os objetos disponíveis, índices da riqueza econômica e espiritual do reino, num processo de inversão satírica, tornam-se os meios pelos quais os inimigos, as plantas revolucionárias, pretendem tomar o poder. No entanto, consumada a derrota das plantas, após acirrado combate, são elas cortadas e seus frutos são cozidos para alimento dos vitoriosos. $\mathrm{O}$

${ }^{104}$ REIMAR, Flavio. Pseudônimo de Gentil Homem de Almeida Braga. Entre o céu e a terra. São Luís: Tipografia de B. de Mattos, 1869, p.83.

105 Op. cit., p.87.

${ }^{106}$ Idem, p.90. 
narrador satisfaz a fome do ministro sem, no entanto, deixar de lhe causar uma forte indigestão, que o tira do serviço por três meses.

Repare-se: ao argumento absurdo, a existência do narrador como vitória régia, soma-se o contexto político - o aumento de impostos em um reino qualquer -, que, por sua vez desencadeia o elemento fantástico de revolução das vitórias-régias que acabará no desfecho farsesco e humorístico das plantas virarem almoço da corte e o primeiro ministro sofrer de um desarranjo intestinal por três meses. O exercício da sátira por parte de Almeida Braga é prática dominante na história, em que se nota a criação do grotesco em consonância com o humor e o consequente ataque a uma figura dominante, no caso o ministro, alvo do elemento satírico ${ }^{107}$. Não parto do pressuposto de que uma história é fonte de outra, se fizéssemos, por exemplo, uma comparação com "Sereníssima República"108; o intuito aqui é outro. Machado voltará a citar Almeida Braga em pelo menos mais duas oportunidades: no próprio "Instinto de Nacionalidade", em que o elenca ao lado de outros poetas, e no necrológio que publica em 15 de agosto de $1876^{109}$, em que, entre outros elogios ao maranhense, refere-se a Entre o céu e a terra, "livro que exprime bem o seu talento original e refletido" ${ }^{110}$. Penso aqui, ainda, evidentemente, em um esquema de referências e não de influências, o que demandaria um estudo comparativo mais aprofundado, que não é o objetivo. Mais que isso, é também tentar mostrar que a evolução do conto no Brasil a partir da década de 1880 não foi um milagre, pois possui alguns precedentes, bem poucos precedentes, é razoável dizer, mas precedentes conhecidos por aqueles que fizeram essa revolução, como é o caso de Machado de Assis.

No capítulo seguinte das "Reminiscências", a duodécima, o narrador se apresenta como a morte, a própria, personificada como os gregos a imaginavam, "filha da noite e irmã do sono". Assim, teria vivido na Grécia e conhecido Safo, a famosa poetisa de Lesbos. Após apresentá-la em um longo período, o narrador ressalva:

Foi muito feliz a poetisa Safo por não ter conhecido no seu tempo entre os prosadores conterrâneos o uso dos períodos extensos como este, que eu acabei de escrever; se o conhecesse ter-se-ia dele servido como de arma de guerra para atormentar o amante e torturar-lhe a paciência. Pode bem ser que um

\footnotetext{
107 Sobre o conceito de sátira, ver FRYE, Northrop. Anatomia da crítica. Trad. Marcus de Martini. São Paulo: É Realizações, 2013, em capítulo dedicado ao tema.

108 Apenas lembremos que no conto de Machado as aranhas estabelecem seu próprio sistema eleitoral, sugerido pelo cônego Vargas, narrador do conto, que é modificado a cada momento em que se verifica uma fraude. Repare-se o absurdo de uma ação política fora do contexto humano, satirizando os atos políticos mesmos do homem.

${ }^{109}$ Publicado na série "Histórias de quinze dias", da Ilustração Brasileira, sob o pseudônimo de Manassés.

${ }^{110}$ Semana Ilustrada, 30 de janeiro de 1870.
} 
período extenso cativasse a benevolência de Faon, à semelhança de uns estirados discursos com que certos oradores rondam os ouvintes de cansaço, deles obtendo a benevolência da fadiga; ao menos dizem os seus admiradores: - ele falou muito -; e o auditório vê-se também constrangido a dizer - não há dúvida, ele falou muito!

Ora, presumo eu que Faon depois de ouvir uns períodos extensos curvasse a cabeça apaixonada e dissesse à amada grega, beijando-a na testa: - falastes muito, Safo; não tenho remédio senão agradecer os teus amores e pagar-tos da melhor maneira! E ninguém me conteste a verídica base da minha presunção; os oposicionistas do ministério Addison diziam à rainha Anna: demiti, senhora, o gabinete; nem podeis deixar de fazê-lo por que o vosso primeiro ministro não fala. Entretanto, o Sr. Zacharias governou o parlamento na sessão de 1867 porque falou muito; os mais enraivecidos oposicionistas confessavam a cada momento: ao menos ele fala e muito, bem que todos seus colegas estejam mudos; mas ele só vale por todos! ${ }^{111}$

Importante dizer que As reminiscências de um transmigrado são compostas, em várias de suas partes, por períodos extremamente longos, que percorrem um parágrafo inteiro muitas vezes, procedimento ironizado no episódio da poetisa Safo. Almeida Braga faz o texto voltar -se sobre si mesmo, manipulando-o de modo a criar humor a partir do próprio material de que se vale. Machado, principalmente após Memórias póstumas de Brás Cubas, vai fazer do procedimento uma das bases de sua escrita satírica. Outro elemento importante no trecho é reparar o caráter digressivo de um narrador que salta do caso de amor de Safo ao gabinete Zacharias no Brasil, numa aparente relação aleatória e casuística entre os fatos, numa premissa fantástica que transpõe o tempo e o assunto. Em trecho mais adiante, em que se encontra com a hetaira Aspásia, diz o narrador:

Aspásia dirigia a festa e conversou com minha alma, depois de concluída a discussão com Sócrates; e tão agradada se ficou dela, que a tomou entre os dedos de rosa e a sorveu, como nós outros podemos sorver uma fruta deliciosa ou um pastelzinho de creme e baunilha. Aspásia sentiu logo em si a existência de duas almas, a minha e a dela; e desta duplicidade espiritual resultou um brilhante fenômeno, mais surpreendente que o de l'ame et la bête de um certo Xavier de Maistre, que há de escrever por aí algures uma grandemente elogiada - viagem em redor do meu quarto. Com duas almas dentro de si viuse Aspásia atarantada; a dela desejava a continuação da festa, ao passo que a minha, ardendo em ciúmes como Othelo e embirrada como um certo Marquês de Paraná a querer que se votasse no Parlamento a reforma eleitoral dos círculos, impunha-lhe a restrita obrigação de acabar com a festa. E a festa acabou-se $\mathrm{s}^{112}$.

A técnica digressiva desse narrador parece mais evidente aqui, o que Machado viria a praticar com Brás Cubas, de forma mais expressiva, onze anos depois. A alusão a

\footnotetext{
${ }^{111}$ REIMAR, p.96.

112 Idem, p. 102.
} 
Xavier de Maistre, autor de quem Machado se apropriaria em Memórias Póstumas, merece uma pergunta. Teria Almeida Braga, dez anos antes de Machado, também se influenciado pelo conde francês? ${ }^{113}$ A citação é explícita, inclusive em relação ao trecho da obra de Xavier de Maistre a que se refere. Não pretendo explorar essa hipótese, mas chamar atenção para o fato de que havia autores brasileiros que estavam desenvolvendo uma literatura de caráter muito menos romântico do que se supunha, com olhos voltados para outro lado, lado para o qual Machado também se sentia impelido a explorar, o que de fato passou a fazer aos poucos na década de 70 e definitivamente na de 80 . Volto à premissa: a evolução do conto no Brasil não brotou milagrosamente da pena de Machado de Assis. Há outras fontes a explorar que, embora poucas e raras, talvez tenham tido um papel mais importante para a evolução do gênero no país do que até agora se pensava.

Esbocemos outra abertura. Observemos o conto "O beijo", de Lúcio de Mendonça, datado de $1876^{114}$, e que se encontra no volume Esboços e perfis, de 1889. Um dos fundadores da Academia Brasileira de Letras, juntamente com Machado de Assis, sabemos que Lúcio de Mendonça firmava estreita amizade com o autor do Cosme Velho desde o início dos anos 70 (Lúcio nascera em 1854), quando Machado lhe prefaciou um de seus livros de poemas, o primeiro, Névoas matutinas, em 1872. Essa amizade iria por toda a vida e, em alguns momentos, Machado e Lúcio dividiram as páginas dos mesmos jornais para os quais contribuíram ao longo de suas carreiras. Havia, portanto, a familiaridade da leitura recíproca e certamente, conforme os dois publicavam na imprensa, cada um possuía a perfeita dimensão do que o outro produzia. Machado, nos anos setenta, como vimos, ainda estava afeito a um modelo de conto romântico, de grande extensão, em que a natureza das peripécias adquiria papel mais relevante que a análise dos caracteres, conforme esboçaria no prólogo de Ressurreição. Já Lúcio de Mendonça, nos seus primeiros contos, procurava desenvolver uma forma sintética, voltada para um final surpreendente, o que seria desenvolvido muito no Brasil através da influência dos contos de Guy de Maupassant a partir da década de $1880^{115}$. Em “O beijo”, o autor trata

\footnotetext{
${ }^{113}$ Falo aqui de uma influência direta que se pode verificar na própria concepção da obra, como penso ser o caso de Almeida Braga. A essa época, Machado já conhecia o autor francês, citado, por exemplo, no conto "Uma excursão milagrosa", publicado em abril e maio de 1866 no Jornal das Famílias. Uma primeira versão desse mesmo conto, sob o título de "O país das quimeras: conto fantástico", havia sido publicada em $O$ Futuro, no dia 1 de novembro de 1862, sem a citação a Xavier de Maistre.

${ }^{114}$ Ainda não tive oportunidade de verificar se o conto fora anteriormente publicado em jornal, de maneira a confirmar a data de escritura. No momento, o tratarei considerando a data da confecção aposta pelo autor. ${ }^{115}$ Em sua tese Contistas à Maupassant: a recepção criativa de Guy de Maupassant no Brasil, Ângela das Neves dedica um capítulo à análise da influência dos contos maupassantianos sobre Lúcio de Mendonça. Nesse estudo, faz a leitura de três contos do autor, publicados no livro Horas do bom tempo, de 1901, com textos, em sua maioria, escritos na década de 1890. Porque trato de textos com datação anterior a 1880,
} 
do romance entre Ângela e Eugênio; ela, uma moça abastada da sociedade carioca que se ressente de uma doença que a debilita; ele, apesar de amigo de infância de Ângela, recémchegado da Europa, de onde não vinha há muito tempo. O ambiente urbano seria um dos que Lúcio utilizaria com relativa frequência em seus contos, embora sua melhor produção é a que está mais estreitamente ligada a um homem rural, não exatamente regionalista, como iremos ver. Nesse conto, ele parte de um motivo bastante comum, que é o do encontro amoroso entre duas personagens, de saída dificultado por algum aspecto exterior a elas, aqui, no caso, uma doença. As caracterizações são limitadas, a moça rica e enferma, o rapaz, antigo amigo de infância, que esteve pela Europa largo tempo, portanto, trazendo em si uma cultura e um comportamento social de um mundo mais "civilizado". O argumento, nesse sentido, não difere muito do conto "A parasita azul”, de Machado de Assis, publicado inicialmente no Jornal das Famílias, em 1872, e depois na coletânea Histórias da meia-noite. A diferença principal é que, no conto de Lúcio, a mulher coloca em dúvida o amor de Eugênio não apenas em função de sua frivolidade, mas também como resultado de interesses econômicos, o que não seria o caso de Isabel com Camilo, em "A parasita azul”, em que a superficialidade dos sentimentos do rapaz parece entrar na equação ${ }^{116}$. Nenhum dos dois contos é necessariamente original nas soluções, mas há neles uma busca, como demonstrou Gledson em relação ao conto de Machado ${ }^{117}$, que visa dar um passo à frente em direção a um modo de criação literária diverso do que se fazia. O conto de Lúcio tem início em um baile, supostamente promovido pela moça para celebrar a volta do rapaz, a quem, segundo os comentários de dois personagens presentes à festa, a moça deita seus olhares. A suposição se mostra correta, pois não demora para que os dois iniciem um namoro, interrompido logo em seguida pelo retorno repentino de Eugênio à Europa, chamado por seu pai, não sem antes firmar um pacto de fidelidade com a moça. Um mês após a partida, o rapaz recebe uma carta comunicando o falecimento de Ângela, que não suportara sua ausência. Note-se o pano de fundo romântico sobre o qual a história se assenta. Os ecos do romantismo ainda se fazem presentes nos escritores daquele momento, embora aqui observaremos algo já um pouco divergente. A peripécia

portanto, antes da apropriação da obra de Maupassant no Brasil, não é possível afirmar que o modelo de conto em Lúcio de Mendonça, em seus primeiros textos, advenha da leitura do autor francês. Ver NEVES, Ângela das. Contistas à Maupassant: a recepção criativa de Guy de Maupassant no Brasil. Tese de doutoramento. São Paulo: FFLCH/USP, 2012.

${ }^{116}$ John Gledson faz uma excelente leitura deste conto de Machado como exercício preparatório para o que o autor faria em Memórias póstumas de Brás Cubas, em que a paródia, no conto apenas ensaiada, explode no romance. GLEDSON, John. "A parasita azul": ficção, nacionalismo e paródia. Cadernos de Literatura Brasileira, números 23 e 24, julho de 2008. São Paulo: Instituto Moreira Salles.

117 GLEDSON, op. cit. 
comanda o andamento e a motivação das personagens, como "acidentes", palavra que Machado usaria depois contra Eça de Queiroz, como já vimos. É um dos primeiros contos de Lúcio e a mão parece ainda um pouco pesada, as situações carecem de uma substância mais convincente. A história prossegue, sintética e com saltos. Eugênio não retorna ao Brasil, como seria de se esperar, mas parte de Paris, onde estava, e segue viagem à Itália, onde se apaixona por uma cantora lírica. Reparem, à notícia da morte da moça, o rapaz prefere fazer um tour pela Europa, talvez para espairecer. O que a moça suspeitara, se confirma: Eugênio era apenas um burguês frívolo, pouco interessado no amor, possivelmente mais um da galeria de pretendentes interesseiros que Ângela devia ter a seu dispor na Corte. No fundo, a questão econômica aqui não é o que mais importa, embora seja dada como pressuposto da aproximação dos amantes, ambos membros de uma classe abastada. Há um aspecto do caráter em discussão, que Lúcio não chega a aprofundar nesse conto, mas que está sugerido e que será tema em outros textos do autor.

Um ano depois, Eugênio retorna ao Brasil com a cantora por quem se apaixonara, que se apresenta no Rio de Janeiro. No teatro, encontra a irmã de Ângela, Júlia, alguns anos mais nova que a falecida Ângela, e por quem logo irá se enamorar! Ao que parece, para Eugênio o amor é uma espécie de moeda de câmbio, que se troca conforme se chega a cada destino. Ele não é apenas frívolo; suas convicções duram o intervalo entre um check in e outro. Volta a frequentar a antiga casa de sua noiva, no Icaraí, onde agora morava Júlia. Num desses encontros, ao solicitar um beijo, a moça lhe promete que o satisfaria somente à meia-noite, no caramanchão do jardim. No horário combinado, esperando-a, Eugênio tem a infeliz surpresa do surgimento de Ângela, em carne e osso, tão viva quanto estamos nesse momento lendo, aparição que lhe provoca um ataque fulminante, matando-o. Até aqui, nada mais romântico. Todo o melodrama, os lances de surpresa da trama, não destoam muito do que se praticava, por exemplo, no teatro brasileiro, como já afirmei antes. O enredo é uma colcha de retalhos de idas e vindas, tudo isso em poucas páginas, o que mais surpreende. No entanto, o conto não terminaria ali. $\mathrm{O}$ narrador retoma a história, refazendo para o leitor o percurso dos acontecimentos. Ângela não era uma alma penada, estava bem viva, e armara para o antigo namorado uma armadilha a fim de testar sua fidelidade. Forjara carta em que comunicara sua morte, esperara o retorno de Eugênio, incumbira sua irmã de seduzi-lo e, por fim, surgiu diante dele. Certo que não contava com um ataque apoplético do moço, mas cada um de seus movimentos fora devidamente planejado. O narrador, voz superior no conto, esclarece e desvenda ao leitor que o sentimento de vingança movera Ângela, que não confiara no 
juramento inicial de Eugênio e resolveu tomar isso a limpo quando o rapaz, após a falsa morte da namorada, não retornou ao Brasil. Reparem que toda a explicação final nada mais faz do que satisfazer uma necessidade de verossimilhança. Ela cria uma sensação de apêndice, felizmente ainda não inflamado, mas que de certa forma demonstra ainda um autor preso a determinadas convenções que lhe forçam a esclarecer o que talvez não precisasse. A forma não está resolvida e nem daria para esperar isso de Lúcio, pelo naquele momento. Entretanto, apesar das restrições levantadas, há dois aspectos bastante relevantes para o que se pretende desenvolver neste estudo. Em primeiro lugar o caráter volúvel de Eugênio, que não só não retornou para sua amada, como logo arrumou outra na Itália, que por sua vez foi trocada por Júlia, sua ex-cunhada, quando voltou ao Rio de Janeiro. O que Ângela desconfiava, que Eugênio não lhe tinha verdadeiro amor e só se ligara a ela por interesse, uma vez que era rica e possuía uma moléstia aparentemente incurável, vê-se confirmado com sua estratégia, que desmascara as reais intenções do rapaz. Estamos falando aqui de um descompasso entre aparência e intenção, denunciado pelos estratagemas do enredo, ainda de forma mecânica, mas que assumirá outras possibilidades posteriormente. Em segundo lugar, o grito aterrorizante que Ângela desprende quando da morte de Eugênio levaria o leitor a pensar em uma reação tão dramática quanto, como se o remorso por ter causado o falecimento do rapaz agora atormentasse a pobre moça. Não é o que se dá, enfim, pois já não cabe mais - por que não há amor? por que não é permitido? - esse tipo de reação, o que o próprio narrador nos esclarece:

- E Ângela? - insiste a leitora impaciente.

Ângela, minha senhora, a minha Ângela esteve a ponto de ser uma heroína de romance: quase foi, aquela mesma noite, lançar-se ao mar, do alto da pedra da Itapuca. Mas não; consolou-se e morreu velha. A culpa não é dela, nem minha: é deste século, em que já se não morre de amor.

Entretanto - ó iniquidade! - foi por não ter morrido de amor que o pobre Eugênio teve afinal que morrer de medo. ${ }^{118}$ (grifo nosso)

O conto de Lúcio de Mendonça já traz aquilo que Machado mais de uma vez vinha apontando em seus escritos dos anos 70, o esgotamento do estatuto romântico. Lúcio nunca terá a mesma veia de humor que Machado, ou a que vimos em Almeida Braga e Luís Guimarães Júnior, e muito menos o humor sarcástico e destruidor de um Raul Pompeia, que ainda veremos. Será sempre mais contido, elemento que mais de um crítico

\footnotetext{
${ }^{118}$ MENDONÇA, Lúcio de. Esboços e perfis; Horas do bom tempo: memórias e fantasias. Apresentação
} de Carlos Sussekind de Mendonça Filho. Rio de Janeiro: Academia Brasileira de Letras, 2003, p.96. 
veio a apontar ${ }^{119}$. O que cabe reafirmar é o quanto a literatura brasileira vinha apresentando sinais de uma mudança estilística já ao longo dos anos 70, opondo-se inicialmente aos valores de uma escrita romântica, em que pese a síntese da narrativa, o estilo contido, a intervenção do humor, o desmascaramento social através da crítica e da ironia. Se, nesse sentido, retomarmos a história do conto no Brasil, perceberemos que a conquista de Machado de Assis a partir dos Papéis avulsos deve também a uma herança um pouco diversa da que vínhamos considerando até agora. Isso quer dizer que a insatisfação com o romantismo, a indefinição do gênero conto em sua forma, ocasionando muitas vezes um hibridismo estrutural nos textos narrativos, com contos longos, novelas curtas, romances retalhados em episódios que mais parecem contos, possa nos mostrar que a conquista da forma do conto envolveu uma dinâmica mais complexa do que supõe a tese do milagre machadiano.

\footnotetext{
${ }^{119}$ O próprio Carlos Sussekind, em sua apresentação da edição da ABL dos contos de Lúcio de Mendonça, que apresenta a escrita do autor como uma "visão absolutamente seca e objetiva dos valores culturais de sua época", citará mais dois autores que traçam um perfil semelhante; Raimundo Correia, contemporâneo de Lúcio, escrevera: "É como prosador, principalmente, que, com melhor realce, se distinguem a individualidade, o temperamento, o poderoso gênio e os inestimáveis predicados do escritor castiço..." (grifo nosso); já Tristão de Ataíde o rotulara de "sobriedade vigorosa". Op. cit., p. XII.
} 


\section{OS LANCES DE ESPELHO EM PAPÉIS AVULSOS}

É já bem conhecida a advertência que Machado de Assis escreveu para a coletânea de contos de Papéis avulsos. Em um texto curto, composto por apenas três parágrafos, o autor explica a razão do título da coletânea, em que relativiza o significado de "avulsos", insinuando, por uma metáfora, que os contos do volume possuem um elemento norteador, que lhes dá parentesco e o autor, como pai, os "fez sentar à mesma mesa". Esboça uma definição sobre o gênero desses escritos, sem chegar a uma conclusão satisfatória. Admite uma indecisão na forma, de modo que alguns dos escritos possam parecer contos, enquanto outros definitivamente não o seriam. Defende-se da impropriedade de alguns não serem contos argumentando que, apesar de não possuírem uma forma familiar ao leitor, podem, ainda assim, despertar interesse. Quanto aos que parecem contos, defendese do aspecto informe argumentando que o conjunto possui um sentido, citando o Evangelho de São João, e que, lembrando Diderot, ao menos distrairiam o tempo do leitor. Se a forma parece inapta, ao menos há um sentido. Se o sentido parece obscuro, ao menos a história entretém. De um modo ou de outro, conclui o terceiro parágrafo, o autor está salvo $^{120}$.

Como outras advertências que escreveu para seus livros, Machado mais sugere do que diz, tão oblíquo quanto sua Capitu. São advertências que, de certa maneira, traem o estatuto de seu propósito. Se "advertir" significa, por um lado, incitar o outro a voltar-se para ver algo, olhar com atenção, precaver-se contra um obstáculo, por outro também implica chegar a uma conclusão, inferir um significado. As advertências de Machado, em especial essa, se cumprem bem o primeiro sentido, porque despertam a atenção do leitor para o que vem à frente, não produzem um esclarecimento sobre o caminho a percorrer. Aí, mais despistam que clareiam. Se são para explicar, o fazem; no entanto, mais deixam em aberto. Ou, se olharmos de outro modo, mais caminhos abrem. Se considerarmos que Machado quase nada explica da ficção que escreve e, quando o faz, quase que a ficcionaliza ${ }^{121}$, podemos entender que suas advertências são portas de entrada de seu pensamento crítico ou mesmo da gênese de suas obras, sem, é claro, desconsiderarmos

\footnotetext{
${ }^{120}$ Papéis avulsos, op. cit., p.3.

${ }^{121}$ Repare-se a nota D escrita por Machado para a edição de Papéis avulsos, referente ao conto "O anel de Polícrates”, em que traça o perfil de um falecido amigo, Artur de Oliveira. O perfil biográfico, eivado de emoção porque feito ao impacto da dor da perda do amigo, mas ainda assim austero e lacunoso, em que a ficção e a realidade se imiscuem para explicar a gênese da personagem do conto, o Xavier, inspirado no falecido Artur.
} 
que podem ficcionalizar o próprio autor, que constrói uma dramatis personae através delas. Assim, lê-las é uma aventura e um risco, em que se pode encontrar belezas raras ou amplas paisagens, ou perder-se em labirintos que terminam em becos. Entremos assim mesmo.

O primeiro parágrafo da advertência a Papéis avulsos aborda a questão da diversidade dos escritos, o fato de serem "avulsos". Sabemos que Machado preparou seus volumes de contos recolhendo histórias já publicadas anteriormente nos jornais para os quais colaborava. São raros os casos de contos inéditos nos volumes ${ }^{122}$. Em alguns casos, portanto, os contos provinham de fontes diferentes, embora o grosso da produção se restrinja a poucos periódicos. Ainda assim, ao contrário das crônicas, a publicação dos contos não seguiu uma regularidade estrita, sendo muito diversa a quantidade de publicações em cada ano durante toda sua carreira, exceção feita a alguns anos da década de oitenta. Se as causas disso podem ser bem diversas, não nos foge, no entanto, a possibilidade de inferir que a irregularidade de publicação dos escritos na imprensa revele menos um desinteresse em relação ao gênero, como escreve na advertência de Histórias da meia-noite (1873), tratando-os como escritos "ao correr da pena"123, que uma preocupação cada vez mais consciente da forma do conto e da dificuldade em atingir com o gênero uma expressão artística. Das páginas "desambiciosas" de Histórias da meianoite, Machado chegará às "pessoas de uma só família” de Papéis avulsos. Se há um elemento de diversidade no conjunto dos contos de 82, que lhes dá caráter autônomo, reforçado pela publicação isolada na imprensa, como se cada conto também pertencesse às notícias daquele dia em que fora divulgado, crônica do tempo, e não mais, há também a ideia de correlação entre eles, considerando que o parentesco, se não aproxima os primos nas ideias, os aproxima na aparência e no sangue, ou seja, na forma e na essência. Isso significa que os contos possuem diferenças aparentes que intentam esconder as semelhanças profundas, e que devem ser mapeadas não por um simples espelhamento, mas por uma sondagem de estruturas mais sutis, que formariam os alicerces da construção de cada conto. Assim, o parentesco denuncia que as divergências de conteúdo e forma

\footnotetext{
${ }^{122}$ Nos Contos fluminenses não se conhece publicação anterior de "Miss Dollar"; de Páginas recolhidas ainda não se encontrou publicação anterior de "Lágrimas de Xerxes"; e em Relíquias de Casa Velha, talvez como o próprio nome indique, cinco dos nove contos eram inéditos: "Pai contra mãe", "Marcha fúnebre", "Um capitão de voluntários", "Suje-se gordo!" e "Umas férias". Cf. SOUSA, J. Galante de. Bibliografia de Machado de Assis. Rio de Janeiro: Instituto Nacional do Livro, 1955.

${ }^{123}$ Papéis avulsos, p.3.
} 
são meras distrações para as convergências de intencionalidade e estrutura. Parecer o que não é para revelar o que é: eis o espírito de Papéis avulsos.

Outro fator a se pensar ainda tem a ver com a escolha feita por Machado dos contos que entrariam no livro. A priori, poderíamos supor que o autor teria um universo de opções que girasse em torno do momento de publicação do volume, ou seja, o ano de 1882. De fato, é o que se verifica na imensa maioria dos contos. Dos doze, nove foram publicados na imprensa entre outubro de 1881 e outubro de 1882. Esse arco estreito faz sentido, pois supõe que o autor estivesse satisfeito com o que conseguira atingir no gênero naquele momento. Um décimo conto merece atenção: "Uma visita de Alcibíades" fora originalmente publicado no Jornal das Famílias em outubro de 1876 e, depois, totalmente reformulado, na Gazeta de Notícias, em janeiro de 1882, versão esta que foi ao livro. Os outros dois contos reunidos no volume foram resgatados de anos que estão fora desse arco: "A chinela turca", publicado em A Época, em 14 de novembro de 1875, e "Na arca", divulgado em $O$ Cruzeiro em 14 de maio de 1877. Se a reunião dos contos publicados em torno de 1882 adquire uma feição bastante lógica - são esteticamente satisfatórios para o autor, o público os reconheceria de modo mais rápido, podendo ajudar as vendas - a entrada de duas narrativas aparentemente distantes e a de uma terceira reescrita despertam alguma curiosidade. O que teria levado Machado a resgatá-los? De 1878 a 1882, ele publicara pelo menos 12 outros contos na imprensa. Por que os deixou de fora?

Para chegarmos a uma resposta razoavelmente satisfatória para as duas perguntas, voltemos à resenha de Machado sobre o livro de Almeida Braga, Entre o céu e a terra:

O escrito de maior fôlego do livro é o que tem por título Reminiscências de um transmigrado; dividido em 12 capítulos, contendo cada qual uma recordação da vida anterior; obra de alegre fantasia e amena erudição, travada às vezes de tristeza, outras vezes (em mal!) de alusões políticas, ainda assim raras e despidas de azedume, porque os ares da poesia têm o condão de sacudir do espírito a poeira cá de baixo. (grifo nosso) ${ }^{124}$

O trecho em destaque nos permite fazer uma leitura das qualidades que Machado observava na escrita de Almeida Braga, que não só foram de seu agrado, mas que alçaram o livro do autor maranhense a um alto grau no conceito do resenhista. Primeiro destaca o humor, imaginação e erudição da história, qualidades que lhe davam leveza, mas não superficialidade, pois dotada de inteligência, e uma graça imaginativa que ao mesmo tempo distraía e agradava. Machado ainda não atingira esse patamar em sua ficção no ano

\footnotetext{
${ }^{124}$ Semana Ilustrada, 30 de janeiro de 1870.
} 
em que publica a resenha. Até aquele momento, pode-se dizer que tentara algo mais imaginativo em apenas dois contos: "O país das quimeras", publicado em $O$ Futuro, em 1 de novembro de 1862, depois levemente alterado com o título "Uma excursão milagrosa", no Jornal das Famílias, em abril e maio de 1866, e "O anjo das donzelas", publicado no Jornal das Famílias em setembro e outubro de 1864, sendo que as versões originais vinham com o subtítulo "conto fantástico". Em "Uma excursão milagrosa" Machado retira o subtítulo; no entanto, uma das alterações que promove em relação a "O país das quimeras" está em todo seu início, que ganha uma introdução explicativa. Nela, em busca de justificar a verossimilhança da extraordinária história que irá contar, o narrador nos previne:

Suponho que os leitores terão lido todas as memórias de viagem, desde as viagens do capitão Cook às regiões polares até as viagens de Gulliver, e todas as histórias extraordinárias desde as narrativas de Edgar Poe até os contos de Mil e uma noites. Pois tudo isso é nada à vista das excursões singulares do nosso herói, a quem só falta o estilo de Swift para ser levado à mais remota posteridade. ${ }^{125}$

A introdução dessa passagem na segunda versão do conto promovida por Machado traz à baila pelo menos três pontos importantes que tangenciam a resenha sobre Almeida Braga e que terão um papel importante na composição de Papéis avulsos:

a) o exotismo, em especial orientalista, que evoca a citação das Mil e uma noites, que estará presente nas viagens do transmigrado em Almeida Braga e que surgirá na composição de "O segredo do bonzo" e no pretexto anedótico de "A chinela turca";

b) o fantástico, evocado pela citação de $\mathrm{Poe}^{126}$, é a base da verossimilhança em Almeida Braga e, também, de Machado em "Uma excursão milagrosa", sem, evidentemente, sofrer do mesmo tom melancólico e taciturno do americano; e que também estará presente em Papéis avulsos, principalmente em "O espelho" e "Uma visita de Alcibíades", embora em tonalidades diferentes;

c) a ironia, lembrada em Swift, que será pontual e política em Almeida Braga, já desviando para a sátira, ainda envergonhada na ficção de Machado até os anos 70, mas que virá feroz e ferina, política e poética, em Papéis avulsos, apesar da restrição que o resenhista faz às alusões políticas (“em mal!”) de Braga; não há peça de ironia política e social mais contundente que o diálogo entre pai e filho de "Teoria do medalhão".

\footnotetext{
125 “Uma excursão milagrosa”, Jornal das Famílias, abril e maio de 1866.

126 Também aqui se poderia pensar na influência de Hoffmann.
} 
Esses três elementos - exotismo, fantástico, ironia - formam um tripé que sustentaria a composição de Papéis avulsos, ao qual eu ainda somaria, pois aludidos na resenha, o humor, a nota pessimista e o cinismo "despido de azedume". Se agora considerarmos essas seis qualidades - exotismo, fantástico, ironia, humor, pessimismo e cinismo - não todas ao mesmo tempo, mas combinadas em grupos permutáveis, podemos vislumbrar os critérios que levaram Machado de Assis a reunir os contos de Papéis avulsos por parentesco e a desconsiderar outros publicados no período. Se num primeiro momento nos saltou à vista o fato de oito dos doze contos terem sido publicados entre 1881 e 1882 na Gazeta de Notícias, jornal que possuía uma linha editorial muito mais progressista e liberal que a do Jornal das Famílias ou A Estação, publicações de caráter conservador, voltadas ao público feminino, num segundo momento o resgate dos contos dos outros jornais mostra que eles possuíam íntimas afinidades com os da Gazeta, demonstrando que mesmo com linhas editoriais restritivas, como é o caso clássico do Jornal das Famílias, Machado vinha procurando uma expressão que fugisse a um padrão romântico conservador e alienante ${ }^{127}$, mas que também não se filiasse ao realismo de matiz naturalista que já chegava da Europa, conforme ilustraria o artigo contra o livro $O$ primo Basílio, de Eça de Queiroz ${ }^{128}$. Assim, podemos concluir que de avulsos esses papéis não têm nada, pois sua reunião envolve critérios a que Machado vinha há bom tempo aludindo e refletindo, elogiando e testando, como veremos adiante.

Entre a publicação de Histórias da meia-noite (1873) e Papéis avulsos (1882), Machado publicou cerca de cinquenta contos, já inclusos os do volume de 82. Era um corpus extenso que teria para incluir no livro, considerando-se apenas o número de títulos. Também a extensão de muitos desses contos, como se pode ver, por exemplo, em "O alienista”, seria item a ponderar. É óbvio que o número de páginas em um livro é um limitador, mas não é o único fator que possa ter determinado a preferência pelos contos da Gazeta de Notícias em detrimento de outros. "A chinela turca" não me parece, por exemplo, tão mais curto que "O imortal”, publicado em A Estação ${ }^{129}$. O primeiro, no entanto, resgatado de A Época, de 1875, com uma pequena alteração, foi publicado, enquanto o segundo, reescritura do conto "Rui de Leão", publicado no Jornal das

\footnotetext{
${ }^{127}$ Sobre a atuação de Machado no Jornal das Famílias, ver CRESTANI, Jaison Luís. "A colaboração de Machado de Assis no Jornal das Famílias: subordinações e subversões". Patrimônio e Memória. Unesp/FCLAs/CEDAP, v.2, n.1, 2006, p.146-175.

128 "O primo Basílio, de Eça de Queiroz". O Cruzeiro. Rio de Janeiro, 16 e 30 de abril de 1878.

129 "O imortal”. A Estação. Rio de Janeiro, julho, agosto e setembro de 1882. O primeiro conto, "A chinela turca", possui 3440 palavras; este, 3751.
} 
Famílias em janeiro, fevereiro e março de 1872, do qual aproveita apenas a ideia central, foi preterido. Tentemos entender o porquê.

Resumindo e especificando alguns dados: no período que vai de 1874 a 1882, Machado publicou contos em três jornais basicamente: o Jornal das Famílias, para o qual contribuiu de 1864 até 1878; A Estação, em que colaborou a partir de 15 de janeiro de 1879 até 1898; e a Gazeta de Notícias, contribuição iniciada em 1881 e encerrada em 1897. O conto "A chinela turca" foi publicado em A Época em 1875 e "Na arca", em $O$ Cruzeiro em 1877. Estabeleceremos como marcos temporais apenas o espaço entre as publicações de "A chinela turca", em 14 de novembro de 1875, e "O imortal", em setembro de 1882, considerando que "Verba testamentária", em 8 de outubro de 1882, foi o último conto a sair em jornal antes da publicação do volume de Papéis avulsos. O primeiro conto por considerarmos que, além de ser, temporalmente, o início do arco de publicações que entrarão em Papéis avulsos, possui elementos fundamentais em relação ao que Machado observou na obra de Almeida Braga, em termos de paródia e sátira, e que seria o tom preponderante do volume de 1882. O segundo, que não foi incluso no livro, por que apresenta pontos estruturais extremamente importantes para analisarmos os critérios que nortearam Machado a escolher dentre uns e outros contos, reforçando a hipótese de que o autor estivesse focado em uma determinada maneira de escrever sua obra a partir de meados dos anos 70 e que não deixaria mais de alimentá-la, exceção talvez feita ao que continuou publicando em jornais femininos, material ainda a ser estudado com mais atenção. Dentro desse espectro, temos, portanto, 16 contos publicados no Jornal das Famílias, 7 em A Estação, os 8 publicados na Gazeta de Notícias, e que foram selecionados para o livro, mais "A chinela turca" e "Na arca".

\section{Humor e sátira em "A chinela turca" e "O imortal"}

Pode-se dizer que "A chinela turca" é o mais simples dos contos de Papéis avulsos. Diferente de todas as outras histórias do livro, não há nele uma teoria elaborada acerca do mundo, da sociedade, da alma humana. Sequer podemos dizer que há uma fina análise psicológica de personagens, como vemos, por exemplo, em "D. Benedita", um dos perfis mais requintados elaborados por Machado, ou mesmo em contos sem maiores pretensões, publicados no Jornal das Famílias, como "Conversão de um avaro"130, de

\footnotetext{
${ }^{130} \mathrm{O}$ colchoeiro avarento Gil Gomes, de 54 anos, será a vítima dos interesses pecuniários do arrivista José Borges, que usará sua prima, uma bela viuvinha de 27 anos, Rufina, como isca. Embora o desfecho seja
} 
junho, julho e agosto de 1878, ou em A Estação, como "Um para o outro"131, de agosto, setembro e outubro de 1879. Em “A chinela turca”, Machado prega uma grande peça ao leitor, pensando em dois sentidos da palavra: o de engodo, tapeação, e o de obra teatral, que também traz consigo a ideia de fingimento.

O conto é um gracioso jogo de disfarces. É noite e o bacharel Duarte está terminando de se arrumar para ir a um baile no Rio Comprido, onde espera encontrar Cecília, uma beldade loira, de olhos azuis, espécie rara no trópico, por quem se apaixonara há uma semana. Seu intento de sair, todavia, é frustrado pela chegada inesperada do major Lopo Alves, um dos "mais enfadonhos sujeitos do tempo" 132 , mas antigo amigo da família, o que lhe demandava algum respeito e consideração. Para desalento do bacharel, a repentina visita tem o objetivo de apresentar-lhe uma obra, um drama teatral escrito pelo próprio major, de cujos pendores literários Duarte vagamente ouvira falar. Como não possui maneira de dispensar o inoportuno visitante, embora não lhe falte vontade, $o$ bacharel afunda em uma poltrona para ouvir a leitura da peça, opúsculo de 180 páginas! A premissa humorística está apresentada, fundamentada no contraste de intenções: o bacharel quer ir ao baile, que possivelmente já se iniciou, mas não pode, pois precisa dar atenção a um velho e entediante amigo da família, que ainda por cima é major, e que resolve, em plena noite de baile, quando o rapaz já estava prestes a sair, a exibir suas propensões artístico-literárias em uma leitura interminável de uma peça teatral. É próprio do humor essa situação contrastante, em que duas vontades se opõem através de ações cômicas e que minam a expectativa do leitor ou plateia. A ironia do narrador busca manipular nossa simpatia para com o drama do bacharel, que se desespera com os minutos que passam e com a péssima qualidade da obra que ouve. Segundo o narrador, em seu drama artístico, o major "não fazia mais do que alinhavar as suas reminiscências"133, numa mistura de cenas, personagens e peripécias de um "romantismo desgrenhado"134. A peça era dividida em sete quadros, completamente destituídos de originalidade, e recheados de lugares comuns de um ultrarromantismo decadente. O narrador resume:

Havia logo no primeiro quadro, espécie de prólogo, uma criança roubada à família, um envenenamento, dous embuçados, a ponta de um punhal e

convencional, com a morte da viuvinha e o empobrecimento do colchoeiro, Machado não poupa uma análise finamente irônica dos protagonistas.

131 Aqui os caracteres são bem exercitados, principalmente os de Henriqueta e Julião, os irmãos protagonistas, que não se separam em função das palavras do pai no leito de morte, o que dá título ao conto. Como é de praxe no Jornal das Famílias, a história é de amor e desenganos, com final lacrimoso.

132 Papéis avulsos, p. 99.

133 Papéis avulsos, p. 103.

${ }^{134}$ Idem. 
quantidade de adjetivos não menos afiados que o punhal. No segundo quadro dava-se conta da morte de um dos embuçados, que devia ressuscitar no terceiro, para ser preso no quinto, e matar o tirano no sétimo. Além da morte aparente do embuçado, havia no segundo quadro o rapto da menina, já então moça de dezessete anos, um monólogo que parecia durar igual prazo, e o roubo de um testamento. (grifos nossos) ${ }^{135}$

A abundância de grifos no trecho acima procura realçar a quantidade de clichês a que a peça do major recorre. Na verdade, nem precisaríamos dos grifos, uma vez que os acúmulos das ficelles já denotam a hiperbólica confusão teatral do enredo imaginado por Lopo Alves ${ }^{136}$. A peça aparenta ter o formato de um grande dramalhão romântico, embora não pareça tão fácil definir a que gênero ela pertence. Vê-se que o cômico da peça não está na intenção do autor, que a tem em alta conta como peça dramática ${ }^{137}$, mas na multiplicação aleatória das peripécias, que acumulam os sentidos do enganoso, do falso, do disfarçado, do aparente, que outras palavras grifadas enfatizam. Todo o conto é o seu contrário, desde o consentimento do bacharel em ouvir a leitura da peça, até a peça em si, que quer ser o que não é, tanto na forma quanto no conteúdo.

A leitura modorrenta do drama produzirá um novo engodo, habilmente introduzido pelo narrador. O bacharel cochila durante a leitura, o que provoca a ira do major, que levanta ressentido, ajunta seu manuscrito e parte antes que o bacharel possa impedi-lo, não que o pretendesse, é claro. O cochilo derruba a máscara social a que o rapaz estava preso, e revela, sem a intenção, o sentimento verdadeiro de Duarte, profundamente entediado com a leitura. A reviravolta é o mote para que o moço retome

\footnotetext{
135 Idem.

${ }^{136} \mathrm{O}$ procedimento das ficelles foi avaliado por um crítico contemporâneo de Machado em 1888. Araripe Jr. constatava o esvaziamento do truque já desde longa data dentro do romantismo, e observava que o seu abandono trouxera nova característica, muito mais expressiva, à literatura brasileira. Em um trecho de sua análise, diz Araripe: "O tédio determinou a reação, e esta fez-se em direção completamente oposta. Visto ter-se o cenário do romance convertido em baldrame de teatro, afogando e multiplicando toda a importância dos personagens; visto haverem-se esses personagens transformados em marionetes ridículos, sem vida, passando a ação a ser apenas uma série de truques previstos e de facílima composição, era indispensável abandonar esse campo de visualidades, sem significação, este objetivismo de fantasia, para ocuparem-se os autores com a alma do homem e com os problemas que verdadeiramente interessavam à humanidade". ARARIPE JR. "Degenerescência da ficelle e queda do romantismo". In: COUTINHO, Afrânio. Obra crítica de Araripe Júnior, vol. II. Rio de Janeiro: Ministério da Educação e Cultura; Casa de Rui Barbosa, 1960, p. 38. Também será a opinião de Antônio Cândido, referência que devo ao texto de Maria Cecília Boechat (2013).

${ }^{137}$ Para Eikhenbaum, "na evolução de cada gênero, produzem-se momentos em que o gênero utilizado até então com os objetivos inteiramente sérios ou 'elevados' degenera e toma uma forma cômica ou periódica. [...] Naturalmente, as condições locais ou históricas criam diferentes variações, mas o próprio processo guarda esta ação enquanto lei evolutiva; a interpretação séria de uma efabulação feita cuidadosa e detalhadamente dá lugar à ironia, à brincadeira e ao pastiche [...]". EIKHENBAUM, Boris. "Sobre a teoria da prosa". In: Teoria da literatura: formalistas russos. Organização de Dionísio de Oliveira Toledo. Porto Alegre: Globo, 1976, p.166. A obra do major encaixa perfeitamente no momento descrito pelo crítico russo.
} 
o plano do baile, anteriormente adiado, e agora, no entanto, frustrado por um homem baixo e gordo que entra na sala e se apresenta como policial. A partir de então, o que caracterizava o drama teatral do major - a profusão das peripécias - passará a orientar os acontecimentos que envolvem o bacharel, como uma espécie de contaminação melodramática. Ele é acusado do furto de uma valiosa chinela turca, comprada por uma senhora a um judeu no Egito. Desconfiado do aspecto fantasioso da história, Duarte não tem tempo de reagir, pois cinco homens, chamados pelo gordo, entram na sua casa e o sequestram. O gordo não é da polícia. Levado a uma casa em um local desconhecido, é posto em uma sala vazia, onde passa a conjecturar sobre os acontecimentos, relacionandoos com Cecília, a beldade loira, e algum rival preterido. Um padre entra e atravessa a sala sem nada dizer. Um homem magro entra e conduz o bacharel a outra sala, onde estava um homem velho, que lhe esclarecerá os fatos: Duarte está ali para casar à força com a dona da chinela, que nunca foi comprada a um judeu e nem veio do Egito, embora não deixe de ser turca. A moça, uma "sílfide", tinha os olhos azuis e os cabelos louros, como os de Cecília. O bacharel se recusa a casar-se e é ameaçado: vai casar, assinar seu testamento e, em seguida, ingerir um veneno. $\mathrm{O}$ padre, que era falso, entra na sala e disfarçadamente lhe oferece ajuda, indicando uma janela. Desesperado, o bacharel salta por ela e corre desabaladamente. Ao cair nos degraus de pedra de uma casa, entra por ela, encontra uma sala e uma poltrona, onde se senta. Diante dele, um homem lê tranquilamente o Jornal do Comércio. É o major Lopo Alves. A folha do jornal diminui de tamanho, quando o major anuncia o fim do último quadro da peça. $\mathrm{O}$ bacharel acordara de seu devaneio. Tudo era falso, menos o fim da leitura. A brincadeira com os gêneros, nesse conto, é uma das mais saborosas que Machado praticou, ele que depois utilizará o procedimento com total desenvoltura em Papéis avulsos, em Memórias póstumas de Brás Cubas e adiante. Evidente que não é a mistura em si que dá possibilidades novas a Machado, mas a maneira hábil com que lida com isso, transformando-a a partir da paródia e do humor, que tenha visto, como já observamos, não só em autores estrangeiros, mas também brasileiros. O bom material pode ser inútil na mão de quem não sabe o que fazer com ele ${ }^{138}$.

\footnotetext{
138 John Gledson, que também estudou a questão dessa fusão de gêneros em Machado, embora não seja seu foco principal, coloca que "esta observação, argumento, ou teoria acerca do uso ágil e hábil de gêneros diferentes tem a vantagem de pôr à mostra um Machado que foi ao mesmo tempo objeto e sujeito da sua situação cultural - achou um lugar, um espaço para experimentar, e de fato esse processo transbordou das crônicas para outros gêneros". Outro ponto importante nesse estudo de Gledson é o modo como ele aponta para a mudança na maneira de escrever de Machado, considerando, um pouco na linha de Roberto Schwarz, que aspectos ligados a uma leitura do tecido social fundaram a base para a reviravolta, tanto no romance
} 
Como se sabe, Machado modificou o trecho final do conto, que se encerrava assim:

Livre do pesadelo, Duarte despediu-se do major jurando a si próprio nunca mais assistir à leitura de melodramas, sejam ou não obras de major. É a moralidade do conto. ${ }^{139}$

José Luiz Passos faz uma leitura importante dessa mudança ${ }^{140}$, primeiro porque visualiza no conto procedimentos que seriam a tônica das melhores obras posteriores, em especial, a mudança da perspectiva narrativa que desvela a interioridade das personagens sem que o leitor perceba integralmente esse desvelamento. Diz Passos sobre o bacharel Duarte: "O escrutínio da sua experiência privada, e sua consciência parcial desse fenômeno, é a matéria do conto"141. Outro elemento importante da leitura proposta por Passos é a ênfase no elemento não-realista (o sonho, a fantasia, a arte), chave privilegiada para o entendimento da maioria das obras machadianas em que ele está presente, a partir do momento em que se relaciona com a realidade cotidiana das personagens, ocasionando, pelo choque, a revelação das incongruências da vida social:

O devaneio do bacharel Duarte, sobrepondo-se exemplarmente a uma obra de arte mal realizada pelo enfadonho major, revela um princípio que passaria a caracterizar o realismo machadiano: a matéria da sua prosa de ficção é a invenção de vidas que por ambição ou gozo se imaginam, pela arte ou fantasia, libertar das limitações das suas próprias circunstâncias e da aparente pequenez dos seus empecilhos. ${ }^{142}$

Ora, parece não restar dúvida quanto à predileção que Machado nutria por esse conto, também levemente sugerida por Passos. O seu resgate, passados sete anos da publicação, com apenas uma pequena, mas significativa alteração, apoia a afirmativa. No entanto, o procedimento a que alude Passos não parece de todo inédito quando da publicação de "A chinela turca". Quero dizer, a dissonância entre o que a personagem é e o que ela imagina ser, e a consciência incompleta dessa dissonância pode ser observada, por exemplo, no conto "O país das quimeras"143, mesmo que pese o seu tratamento alambicado e romântico, indeciso entre o sério e o ridículo. O procedimento em si, portanto, não é o definidor do que virá a atingir a obra de Machado. Já temos ali, no conto de 62, a crítica a uma postura romântica e um distanciamento que não se resolve entre o

quanto no conto, já a partir do meio da década de 1870. GLEDSON, John. "Machado de Assis e a crise dos quarenta anos". Machado Assis em linha, Rio de Janeiro. v. 4, n. 8, p. 10-31, dezembro 2011.

${ }^{139}$ A Época. Rio de Janeiro, 14 de novembro de 1875.

${ }^{140}$ PASSOS, José Luiz. Machado de Assis: o romance com pessoas. São Paulo: Edusp/Nankin, 2007.

${ }^{141}$ PASSOS, p.82.

142 Idem, p.83.

143 O Futuro, 1 de novembro de 1862. 
ser e o parecer ${ }^{144}$. O que falta a esse conto e sobra em "A chinela turca" é o uso da fantasia enquanto procedimento paródico, gerador de humor e, portanto, de distanciamento da perspectiva das próprias personagens. O poeta das quimeras nos dá pena porque a paródia ali se veste de modo grave, enquanto o drama de Duarte e do major nos faz rir pelo ridículo dos contrastes. A mudança de perspectiva que Machado procurava alia humor e fantasia em uma fatura frequentemente antirrealista, como se dará predominantemente em Papéis avulsos. Na reescrita que Machado faz do conto de $62^{145}$, na verdade algumas alterações, a distância em relação à perspectiva da personagem se amplia, pois o conto deixa de ser um conto fantástico para ser o relato verídico da viagem do poeta, verossimilhança calcada na "amena erudição" do narrador, que cita outros relatos de viagem - verídicos e fictícios - para corroborar a verdade do que vai transmitir. Ademais, a versão de 66 acrescenta outros dois pontos que serão elementos frequentes das narrativas posteriores, como em "A chinela turca" e em todos os contos de Papéis avulsos.

O primeiro ponto é a introdução de uma nova personagem, um filósofo, que expõe ao poeta uma teoria sobre o Universo. Teorias explicativas do homem e do mundo serão frequentes na ficção machadiana posteriormente, sempre com viés satírico, no sentido de elaborarem uma leitura absurda, mas plausível, da alma e da vida. O Humanitismo de Quincas Borba é a mais conhecida dessas teorias, mas lembremos como em Papéis avulsos elas se multiplicam em "O alienista", "Teoria do medalhão", "O segredo do bonzo", “A sereníssima república” e, numa fatura fantástica, em “O espelho”. Em "Uma excursão milagrosa", a teoria em si não atinge o nível paródico das citadas anteriormente, embora a situação em que é apresentada se revista de uma gravidade cômica, mas explicita um dos pilares da ficção de Machado, que é a fissura entre as convicções do ser e do parecer. Citarei o trecho integralmente, pois me parece bem explícito:

Dizia o filósofo:

- Meus caros filhos, o universo é um composto de maldades e invejas. Não há talento, por mais prodigioso, que não seja ferido pela seta da calúnia e do desdém dos egoístas. Como fugir a esta triste situação? De um modo único. Que cada um começando a viver deve logo comprometer-se de que nada há

\footnotetext{
${ }^{144}$ Lembre-se como o narrador de "O país das quimeras" caracteriza o poeta Tito, protagonista da viagem fantástica, carregando no contraste entre o sério e o ridículo: "Como as medalhas, e como todas as coisas deste mundo de compensações, Tito tem um reverso. Oh! triste coisa que é o reverso das medalhas! Podendo ser, do colo para cima, modelo à pintura, Tito é uma lastimosa pessoa no que toca ao resto. Pés prodigiosamente tortos, pernas zaimbras, tais são os contras que a pessoa do meu amigo oferece a quem se extasia diante dos magníficos prós da cara e da cabeça. Parece que a natureza se dividira para dar a Tito o que tinha de melhor e o que tinha de pior, e pô-lo na miserável e desconsoladora condição do pavão que se enfeita e contempla radioso, mas cujo orgulho se abate e desfalece quando olha para as pernas e para os pés".

145 “Uma excursão milagrosa”. Jornal das Famílias, abril e maio de 1866.
} 
acima de si, e desta convicção própria nascerá a convicção alheia. Quem há de contestar o talento a um homem que começa por senti-lo em si e diz que o tem?

Os ouvintes alçaram a voz e num coro exclamaram:

- Muito bem!

O filósofo continuou:

- Dirão que isso é vaidade; mas se bem compreendeis a nossa natureza e a natureza dos outros deveis saber que isso que lá embaixo se chama vaidade não é entre nós outra coisa mais do que a verdadeira tensão do espírito, a consciência da nossa elevação moral. ${ }^{146}$

Repare-se que o parecer surge como mecanismo de defesa do ser, que deve "compenetrar-se" de uma "convicção" a ponto de o outro acreditar piamente no que vê. A sugestão de que "nada há acima de si" se reveste de um elemento malicioso, de exercício do poder, que depois Machado trabalhará com finura e crueldade nas Memórias póstumas de Brás Cubas ${ }^{147}$. Aqui, portanto, em 66, Machado já trabalha com a ideia de que a aparência, mais que a essência, sustenta o comportamento humano, de modo que a mudança de perspectiva dos narradores vem a ser a consequência técnica, ou a solução artística, para uma problemática com que o autor já se preocupava antes. Aqui ainda falta sutileza, e Machado sabia disso, o que nos leva ao segundo ponto.

O segundo ponto se refere à modificação feita por Machado no final de "Uma excursão milagrosa". Aliás, mais do que modificar, ele aumenta o trecho final, adicionando um comentário do narrador, que aparenta ser uma palavra de ordem da narrativa, que revela a realidade, disfarçando-a no véu do irreal, como é do caso do conto e do realismo particularíssimo de Machado. Diz o narrador:

É a sorte de todos quantos entendem dever dizer o que sabem; nem se compra por outro preço a liberdade de desmascarar a humanidade.

Declarar guerra à humanidade é declará-la a toda a gente, atendendo-se a que ninguém há que mais ou menos deixe de ter no fundo do coração esse áspide venenoso.

Isto pode servir de exemplo aos futuros viajantes e poetas, a quem acontecer a viagem milagrosa que aconteceu ao meu poeta.

Aprendam os outros no espelho deste. Vejam o que lhes aparecer à mão, mas procurem dizer o menos que possam as suas descobertas e as suas opiniões. ${ }^{148}$

Parece haver algo contraditório no trecho. De início ele conclama aos que entendem o "dever de dizer o que sabem"; ao final que "procurem dizer o menos que

\footnotetext{
146 "Uma excursão milagrosa".

${ }^{147}$ Lembremos o episódio do ex-escravo Prudêncio no capítulo LXVIII, "O vergalho", flagrado ao castigar seu próprio escravo na rua. O flagrante, dado pelo antigo senhor, Brás Cubas, serve de introdução a uma reflexão, entre cínica, irônica, mas principalmente, devastadora, da natureza humana, elaborada pelo narrador.

148 “Uma excursão milagrosa".
} 
possam”. Será de fato uma contradição? Como de costume em Machado, muito do significado está no não dito, no avesso, no silenciado. O trecho acima é a moral do conto, que procura "repreender" o poeta da história, que vendia suas obras a um homem rico, que as assinava como sendo suas. O que o poeta sabia, vendia a quem o ignorava. Mas creio que a lição vai além e toca exatamente no ponto que parece contraditório, mirando outro alvo que vem a ser a produção posterior de Machado, ou o seu ideal de escrita. Entrar em guerra com a humanidade é revelar as suas verdades negativas mais íntimas. A maioria dos contos do Jornal das Famílias, por exemplo, se nega a essa guerra, pois, embora esses textos escavem os jogos de enganos nas relações sociais e amorosas, dificilmente vão ao mais fundo das motivações das personagens. Há surpresas, as personagens disfarçam seus interesses econômicos ${ }^{149}$, mas as motivações fundamentais não são detalhadas, ficando as histórias, em geral, resolvidas quanto aos conflitos, dentro de um sistema convencional e romântico de punições e compensações. Talvez, exatamente, porque tudo seja mais superficial e claro, implicando a consequência às personagens, Machado ainda procura a sutileza, como disse antes, e dizer o menos não significa calar, mas dizer da forma mais velada, menos explícita, mas não menos contundente. Nesse sentido, a inversão (do narrador, da perspectiva, da ironia, do ponto de vista da personagem) se dá pela junção de todos esses elementos a um humor antirrealista, mesmo nos contos que mais se aproximem de um chamado estatuto de real.

Parece, enfim, que, com "A chinela turca", a necessidade de apego a esse suposto estatuto realista, aquele mais apegado à ideia do referente como base da verossimilhança, cada vez mais se desvincula da proposta machadiana, que não pretende, nesse caso, enveredar pelo fantástico de Hoffmann e Poe, mas que, versado na lição de humor e fantasia de autores estrangeiros como Swift, Voltaire, Cervantes, como tanto aponta a crítica machadiana, e na de brasileiros como Luís Guimarães Junior e Gentil Homem de Almeida Braga, mira um projeto de desvelamento do real através de um deslocamento da própria realidade, seja pela paródia, seja pelo delírio, pela inversão de perspectiva, pela ironia, pelo contraste, pela fantasia, pela sátira, pela negativa, em suma, pela recusa de uma escrita condescendente com padrões estabelecidos. O péssimo melodrama do major Lopo Alves e o desinteresse fantasioso do bacharel Duarte, que cria uma realidade

\footnotetext{
149 Veja-se, por exemplo, as ações meritórias disfarçadas de interesse dos primos Marcos e Eugênia em relação à tia rica, Dona Venância, em "A herança" (Jornal das Famílias, abril e maio de 1878). O final recompensa a relação desinteressada, ficando a herança do título a um terceiro sobrinho, Emílio, que achava a tia aborrecida.
} 
paralela e paródica, sintetizam melhor o que o autor vinha procurando e por isso se encaixam tão bem no que encontrou com os contos de Papéis avulsos.

\section{"O Imortal"}

Quase todos os contos de Machado no período que vai de 1875, quando da publicação de "A chinela turca", a 1882, quando do lançamento de Papéis avulsos, tratam de histórias de amor e desengano, exceção feita aos publicados no próprio volume de 82. Se é justo recordar que nesse período o autor publicou 17 contos no Jornal das Famílias e 9 em A Estação, revistas voltadas quase exclusivamente para o público feminino com uma linha editorial conservadora, como dissemos anteriormente, e que desses 26 contos aproveitou apenas $3^{150}$, sugerindo que, de certa maneira, o autor procurava se limitar aos preceitos dessas publicações, também é correto ver que dos 8 que saíram na Gazeta de Notícias, cujo progressismo e liberdade editorial eram notórios, todos foram publicados no volume de Papéis avulsos, denotando que Machado estivesse se empenhando artisticamente mais para os contos que publicava aí, uma vez que colaborou simultaneamente para os dois veículos ${ }^{151}$, A Estação e a Gazeta de Notícias.

Assim, se para a coletânea de Papéis avulsos, Machado desprezou o que havia publicado no Jornal das Famílias ${ }^{152}$, para o qual deixou de colaborar com o fechamento da revista em 1878, o mesmo não aconteceu totalmente com os contos de A Estação, embora tivessem eles o mesmo público feminino do primeiro. Se "D. Benedita" agradava àquele público, por ser um conto que desenha um perfil feminino, embora vá muito além dos perfis românticos, a publicação de "O Alienista" em A Estação já não seria tão simples de explicar. Talvez a Gazeta, naquele momento, não aceitasse publicar uma história tão longa - todos os contos na Gazeta saíram em um único dia - e A Estação passou a ser o veículo apropriado. Razão pragmática, sem dúvida, não descartável. Após “O Alienista", publicado de 15 de outubro de 1881 a 15 de março de 1882, quinzenalmente, Machado publicou na revista o conto "D. Benedita”, em cinco partes, de

\footnotetext{
150 "O alienista" e "D. Benedita”, publicados em A Estação, e "Uma visita de Alcibíades", no Jornal das Famílias, que, no entanto, foi completamente reescrito e republicado na Gazeta de Notícias.

${ }^{151}$ Em Histórias sem data, o padrão se repetiria: dos 18 contos do volume, 15 seriam da Gazeta de Notícias e apenas 2 de A Estação. O último seria da Gazeta Literária.

152 A justificativa de exclusão pela data de divulgação seria inverossímil, uma vez que "Verba testamentária", último conto a ser compilado, saiu na Gazeta de Notícias em 8 de outubro de 1882. "O imortal" saiu até setembro. O volume certamente saiu do prelo em outubro, pois a primeira resenha conhecida do livro é assinada por Gama Rosa, em 2 de novembro na Gazeta da Tarde. Para essa informação, ver MACHADO, Ubiratan (org.). Machado de Assis - roteiro de consagração. Rio de Janeiro, Ed. UERJ, 2003, p. 140.
} 
15 de abril a 15 de junho, e, em seguida, "O imortal”, também em cinco partes, de 15 de julho a 15 de setembro ${ }^{153}$. Os dois primeiros foram aproveitados em Papéis avulsos; o terceiro, não. Mas, que razão teria levado o autor a excluir esse texto? Ele parece bem mais aparentado aos contos de Papéis avulsos que aos excluídos das revistas femininas. Ou não?

Vejamos. Machado de Assis escreve contos para revistas de moda desde 1864, quando publicou "Frei Simão" no Jornal das Famílias. Em A Estação, revista de mesmo estilo, o autor apenas deu continuidade, até 1898!, na escrita de histórias para um público burguês feminino. Se por um lado a ideia de ruptura da obra machadiana produziu grande fortuna crítica, estabelecendo como marco a publicação de Memórias póstumas de Brás Cubas, em 1881, e do volume de contos de Papéis avulsos, em 1882, por outro poderíamos estabelecer uma grande linha de continuidade, evolução, repetição, retrocesso e avanço, ou seja, uma grande espiral de idas e vindas, se lêssemos apenas os contos publicados nessas duas revistas. A noção de receptor em Machado é muito presente, noção que acaba por ser mimetizada e satirizada por narradores impertinentes que dialogam com o leitor. Não é essa uma ideia abstrata; para Machado, o leitor está concretamente próximo, discutindo política em um café ou comprando revistas francesas de moda na rua do Ouvidor. Nesse sentido, quando Machado atinge uma nova forma para seus contos, a partir dos anos 80 , ruminados nos 70 , e desde então escolherá apenas esses para figurar em volumes, é que se pode observar que a ideia de uma ruptura absoluta entre dois Machados é incongruente. Na prática ela não existe. O binômio MachadoMachadinho que se pode usar para ilustrar essa diferença não configura, de fato, que o primeiro haja substituído o segundo, tendo sido este enterrado com Brás Cubas, no caso do romance, e com Papéis avulsos, no caso do conto. O que se vê, após 1880, é a existência de um duplo, a coexistência de dois modelos de escrita, - no conto, diga-se de passagem - que dão à produção do autor no gênero uma ambiguidade que a crítica pouco tem se aventurado a explorar, Dr. Jekyll and Mr. Hyde, - se aceitarmos o modo pejorativo como os contos da "primeira fase", anteriores a Papéis avulsos, são tratados - é como poderíamos entender a produção de Machado para essas revistas femininas.

De 1874 a 1881, a tônica dos contos publicados nessas revistas é a mesma: histórias de amor e enganos, permeadas de interesses econômicos, paixões fortes, intrigas, mortes, lances dramáticos, lágrimas, desencontros, traições, finais felizes ou trágicos,

${ }^{153}$ Lembrando que "Uma visita de Alcibíades", publicado originalmente no Jornal das Famílias, foi reaproveitado após ser reescrito e republicado na Gazeta de Notícias. 
heróis e heroínas jovens, em geral puros, e títeres, ou do destino ou do interesse alheio. É uma fórmula, e a leitura seguida desses contos acarreta uma sensação de monotonia. No entanto, era o esperado por aquele público, que almejava encontrar o que conhecia e lhe agradava. "A chinela turca" e "Na arca", que não cabem nesse esquema porque lidam diretamente com a paródia, não foram publicados nessas revistas. "Uma visita de Alcibíades", que o foi, foi bastante modificado na sua segunda versão, que, afinal, também não se encaixava no esquema, embora abordasse tema familiar às moças, que eram os ditames da moda no tempo. "O alienista", publicado em A Estação, em tudo se afasta. E "D. Benedita" não se encaixa pela profundidade de análise a que Machado aí se dedica, apesar do chamariz brejeiro da primeira frase ${ }^{154}$. Assim, facilmente se verifica que os contos do Jornal das Famílias e A Estação possuíam uma qualidade e intencionalidade diversas dos de Papéis avulsos; se nestes, o tom paródico e satírico se estabelece pelo contraste entre a seriedade dos temas e o tratamento jocoso e irônico dos atos, naqueles, a brejeirice e leviandade dos argumentos recebe tratamento, se não elevado, ao menos respeitoso, o que quebra o estranhamento entre conteúdo e forma, alicerce de Papéis avulsos. Não só porque as moças levam os contos muito a sério, no sentido de encontrarem o que esperam e então se comoverem ou se deleitarem, mas porque Machado, nessas revistas, acaba por tentar satisfazer essas expectativas. Se não são más histórias, e várias de fato são muito boas, ainda assim se mostram delimitadas por um estatuto romântico, esvaziado e obliterado, ou seja, um romantismo de tipo machadiano, burguês, de extrato urbano, nas pegadas, agora um pouco mais amaneiradas, de Macedo e Alencar ${ }^{155}$. No entanto, "O imortal” não parece se encaixar aí.

"O imortal", assim como "O espelho", se reveste de uma dupla narrativa, uma emoldurada pela outra, em que a de verniz realista envolve a de fundamento fantástico, forçando-lhe o aspecto de verossimilhança ${ }^{156}$. No conto, o Dr. Leão narra a dois ouvintes - um fazendeiro, o coronel Bertioga, e um tabelião, João Linhares - a história de seu pai, Rui de Leão, que nascera em 1600. Eles estão em 1855. Obviamente a veracidade da

\footnotetext{
154 “A cousa mais árdua do mundo, depois do ofício de governar, seria dizer a idade exata de D. Benedita". Papéis avulsos, p.127.

${ }^{155}$ A mera listagem dos títulos já dá uma ideia do teor dessas histórias. Apenas como amostra, veja-se: "Muitos anos depois", "Miloca", "Valério", "Antes que cases", "Brincar com fogo", "A mágoa do infeliz Cosme", "A última receita", "Onze anos depois", "Casa, não casa...", "História de uma fita azul", "To be or not to be", "Longe dos olhos...", "Encher tempo", "O passado, passado", "Dona Mônica", "O astrólogo", "Sem olhos", "Um almoço", "A melhor das noivas", "Um ambicioso", "A herança", "Conversão de um avaro", "Folha rota", "Dívida extinta", "Um para o outro", "A chave", "O caso da viúva", "A mulher pálida".

${ }^{156}$ Para a questão da verossimilhança em "O imortal", ver HANSEN, João Adolfo. "O imortal" e a verossimilhança. In.: Teresa, revista de Literatura Brasileira [6/7]; São Paulo, 2006, p.56-78.
} 
história é questionada, mas o Dr. Leão, sem necessariamente convencer seus ouvintes, consegue despertar-lhes a curiosidade para o narrado. Verdade ou mentira, fato é que a história lhes parecia boa. Veladamente, firma-se entre os três um pacto ficcional, em que o narrado, independentemente de sua veracidade, necessita ao menos fazer-se crível, para que o receptor o aceite como narrativa. Como bem mostra Hansen em seus detalhes ${ }^{157}$, o pacto vai se firmando em função da habilidade do narrador em satisfazer o horizonte de expectativas de seus ouvintes (e leitoras!), criando uma narrativa de características profundamente românticas, na sua sucessão de "aventura, intriga, amores"158. Também "A chinela turca" não se mostra diferente: a sucessão de eventos, tanto do drama do major quanto da imaginação do bacharel, cumpre as expectativas de uma literatura romântica. No conto de 75, esse acúmulo tem função paródica, no sentido de desvirtuar o discurso romanesco ao tom do ridículo. $\mathrm{O}$ alvo e a intenção são expressivos pelo cômico das situações. Mas em “O imortal” não? Escreve Hansen:

Por serem exageros aplicados com redundância, tornam cada ponto e o todo do conto também redundantes e exagerados. O patetismo dessa contínua agitação exterior é uma deformação; como deformação, as paixões intensas a solidão moral, a paixão amorosa, a honra ultrajada, o desespero suicida etc. -, que passavam por sublimes, digamos que entre 1830 e 1870 , são efetivamente cômicos em $1882 .{ }^{159}$

Não me parece haver dúvida em concordar com Hansen pelo que vai acima, e Machado certamente também já o sabia desde os anos 70, pelo o que o autor já vinha escrevendo sobre o esvaziamento das concepções ultrarromânticas e sentimentais, mas especialmente sobre o histrionismo causal das relações românticas. Um conto como "Frei Simão", que tangencia esse histrionismo, chega a ser constrangedor na sua tentativa capenga de causar comoção. Em "Frei Simão", conto de 64, Machado ainda aceita o modo romântico como se mostrava naquele momento. Não será o caso nos anos 70, em que o seu romantismo se torna cada vez mais aburguesado, em tom menor, mas, por outro lado, cada vez mais próximo de suas leitoras em termos de identificação. No conto "O imortal", Machado parte do modelo tradicional romântico, o da grande aventura, repleta de acontecimentos, amores, reviravoltas; no entanto, tem outra meta, segundo Hansen, porque é a partir da exageração desse modelo que ele atinge o paródico, repetindo - ad infinitum, como seria - o mesmo padrão narrativo. Sendo justa a observação, o propósito

\footnotetext{
${ }^{157}$ HANSEN, op. cit.

${ }^{158}$ Idem, p.69.

${ }^{159}$ Ibidem, p.69.
} 
de "desnaturalizar" a expectativa romântica da leitura promovida por "O imortal", aproximando-o, nesse sentido, de todos os outros contos de Papéis avulsos e livros posteriores ${ }^{160}$, seria motivo suficiente para incluí-lo em qualquer dessas coletâneas. Mas não o foi. E não foi porque esse elemento paródico para que Hansen aponta não foi trabalhado o suficiente por Machado no conto, como o foi em outros, o que não apenas justificaria a sua exclusão, como nos indicaria o que realmente o autor estava procurando atingir em Papéis avulsos. Entender o que falta em "O imortal" é entender o que está presente nos demais.

Portanto, o que lhe falta?

Em suma, falta-lhe o cômico. Essa afirmação pode parecer contraditória com o que veio nos parágrafos anteriores, mas não é. A ideia do acúmulo dos lugares-comuns românticos atingirem um patamar cômico, como afirma Hansen, e como vimos em "A chinela turca", é correta e se ajusta bem a uma leitura do período e a um certo modo de exercer a paródia e a sátira. Vê-se isso também em "O alienista", em que o excesso de racionalismo de Simão Bacamarte leva à sátira de um pensamento cientificista que dominou a segunda metade do século XIX. Também se vê na repetição de experiências pseudocientíficas em "O segredo do bonzo". E, também, na pródiga capacidade do Xavier em produzir ideias de pacotilha que não lhe dão fruto algum em "O anel de Polícrates". Esses exemplos nos fariam entender que o acúmulo e a repetição, por si, seriam geradores do cômico. No entanto, não é o que ocorre. Ao olharmos “D. Benedita", talvez a questão fique mais clara.

Também publicado em A Estação, como "O imortal”, "D. Benedita” é um conto que se encaixa bem naquela revista feminina. É um retrato, como outros que Machado já fizera em seus contos, de um tipo feminino facilmente identificável para suas leitoras. Já chamei a atenção para a frase que abre o conto, que traz um ar de familiaridade reconfortante, como a própria D. Benedita apertando a mão de D. Maria dos Anjos entre as suas numa reunião íntima. A familiaridade aqui também serve para outro aspecto, o qual o narrador irá incorporar completamente, o da volubilidade e superficialidade dos desejos de D. Benedita. Nesse caso, o narrador parece narrar sua história como se contasse uma fofoca, dita entre dentes e risinhos e intercalada por digressões inúteis. Em "D. Benedita", o narrador é principalmente fútil. Todo o seu detalhismo de cena e de

\footnotetext{
160 “Como 'A chinela turca', 'Singular ocorrência', 'A cartomante' e outros contos, 'O imortal' joga com o arbitrário da direção narrativa, dissolvendo a verossimilhança tradicional por meio da estilização e paródia da mesma como gênero cômico". HANSEN, op. cit., p.77.
} 
observação atentam para os elementos mais comezinhos e superficiais da dona da casa, num acúmulo labiríntico de rendas, bordados, docinhos, romances, toucados, beijinhos e outros diminutivos que tornam o conto impróprio a diabéticos. Tal acumulação de doçuras e futilidades se torna cômica não porque apenas se repetem, mas porque o narrador as incorpora integralmente, gerando o ridículo, pois, sendo também sua a volubilidade e superficialidade, consegue, sem freios, dar vazão inconsciente a toda sua estupidez pessoal e de classe. Pois não é isso o que faz Brás Cubas?

O narrador de "O imortal”, por incrível que possa parecer, não o faz. Seu relato aos dois ouvintes é constrangido. Sua posição é a de quem quer provar algo, daí sua necessidade de intercalar provas de verossimilhança. Se o acúmulo das situações românticas é cômico, e de certa forma o é, o Dr. Leão, no seu pudor filial, procura invariavelmente conter esse riso, dando explicações, estabelecendo causas, racionalizando o quanto pode a história do pai. Dessa forma, o conto em si parece também envergonhado, pois não se permite que a sátira o domine completamente, fazendo sorrir a meio tom, amarelo e pálido. O que falta a esse narrador, talvez porque o vínculo familiar não o permita, e os saltos que dá à narrativa talvez funcionem como ato de censura ao ridículo, é o desprendimento que sobra ao de "D. Benedita", o rigor do detalhe de Jacobina em "O espelho", o amor à razão de "O alienista". Se por um lado "O imortal" está um passo à frente dos contos do Jornal das Famílias e de A Estação, porque supera o esquematismo das histórias de amor e engano românticas, intentando parodiá-las pela repetição cumulativa, por outro está aquém das histórias de Papéis avulsos, porque se amedronta em abrir-se à sátira plena e ao cômico, "desnaturalizando" a leitura através de um narrador sem freios. Aqui, se cabe o trocadilho, o narrador tenta nos dar o cômico em doses homeopáticas, porque sua especialidade, mas nos dá uma espécie de sátira amaneirada que, convenhamos, similia similibus curantur, se parece a um romantismo amaneirado. Se as leitoras de A Estação riram das loucuras de Simão Bacamarte e das futilidades de D. Benedita, talvez tenham mais suspirado com as agruras e angústias de Rui de Leão. O alvo de Machado certamente era a sátira, mas o autor falhou no tom que deu à execução, por isso o excluiu da coletânea de Papéis avulsos. A mortalidade é para todos.

Pode-se dizer, enfim, que Machado chega à coletânea de Papéis avulsos com um conjunto de procedimentos bem definido, apreendido na sua consciência de escritor e leitor, e que, somente tomados em conjunto é que podem definir sua ficção: um antirrealismo que beira o fantástico, um gosto pelo estranhamento, uma observação fina 
das contradições humanas e sociais, um humor de aguda inteligência, um negativismo crítico e sem compaixão, um desprendimento cínico perante as idiossincrasias humanas e, por fim, uma habilidade ímpar em metamorfosear-se sob pontos de vista diversos. Tudo isso operando para o desvelamento das camadas mais íntimas de suas personagens, de seus segredos mais obscuros, que se ocultam sob vernizes de máscaras sociais e que objetivam cimentar a fissura entre o ser e o parecer porque, e aí é o ponto de vista de Machado, as essências não são belas como as aparências. 


\section{DUAS FACES DE UMA MOEDA:}

\section{OS CONTOS DE RAUL POMPEIA E LÚCIO DE MENDONÇA}

Raul Pompeia foi uma espécie de menino prodígio das letras brasileiras. Com 17 anos, ainda estudante do Colégio Pedro II do Rio de Janeiro, já publicara uma novela, Uma tragédia no Amazonas, que, a despeito de suas questões ainda imaturas de forma, chamou atenção da crítica para o talento literário de um garoto ousado e eloquente ${ }^{161}$. Estudante de Direito em São Paulo, participante ativo das questões políticas desde cedo, tendo logo abraçado fervorosamente a causa republicana e o abolicionismo, não demorou muito para que o estudante chamasse a atenção dos jornais e passasse a contribuir com a imprensa, inicialmente de São Paulo e depois do Rio de Janeiro, onde passou a residir em 1885, após terminar o curso de Direito em Recife, para onde migrara com outros 93 estudantes reprovados pela Faculdade de Direito de São Paulo por motivos não exatamente acadêmicos. Seus trabalhos publicados em jornais (contos, crônicas, poemas em prosa, crítica literária, artigos políticos, desenhos e caricaturas) preenchem oito volumes de sua obra completa, publicada em dez partes. O terceiro volume engloba os contos, cerca de 50, publicados entre 1881 e 1890. Não é uma produção pequena, se considerarmos que Machado de Assis, que publicou algo em torno de $215^{162}$, o fez durante 50 anos. Essa produção, infelizmente, como aconteceu com boa parte do que se publicou nos jornais do século XIX, ficou por muito tempo relegada ao pó, não permitindo que os contos de Raul Pompeia pudessem ter sido melhor estudados e assimilados por gerações de críticos e escritores. A publicação do conjunto dos contos em volume se deu apenas em 1981, cem anos após a publicação do primeiro no jornal A Comédia, de São Paulo, em abril de 1881. Esse hiato cria uma questão, evidentemente: por terem ficado esquecidos nos jornais da época, teriam eles agora relevância para serem colocados dentro de uma linha evolutiva do conto no Brasil? Em 1949, em meio a suas idiossincrasias notórias, Graciliano Ramos chamava a atenção de Otto Maria Carpeaux para alguns

\footnotetext{
${ }^{161}$ Informa-nos Eugênio Gomes sobre o assunto: "Não obstante as suas evidentes falhas, a tumultuária novela permitiu Capistrano de Abreu prognosticar que Raul Pompeia, juntamente com Aluísio Azevedo, seria um dos maiores romancistas da nova geração". GOMES, Eugênio. "Raul Pompeia, contista". In.: POMPEIA, Raul. Contos. Obras, vol.3, org. de Afrânio Coutinho. Rio de Janeiro, Civilização Brasileira/OLAC, 1981, p.14.

${ }^{162}$ Para ser mais preciso, 218, como consta da edição em quatro volumes dos contos completos, organizada por Djalma Cavalcante. Ver ASSIS, Machado de. Contos completos. Organização de Djalma Cavalcante. Juiz de Fora: UFJF, 2003. O que não significa, necessariamente, que o número esteja fechado.
} 
contos de qualidade esquecidos nos jornais do século anterior. Não falava em grandes contistas, dentro da sua característica categórica e mal humorada que lhe era peculiar, mas dizia a Carpeaux:

- Há uns tempos - começa Graciliano - andei estudando aquilo que se chama conto brasileiro. Sérgio Buarque de Holanda abriu-me com a maior gentileza os, digamos, tesouros da Biblioteca Nacional. Passei lá três meses, folheando velhas revistas e jornais. Quanta coisa obsoleta, quanta besteira! No entanto, eu já dizia a você que os verdadeiros contistas brasileiros são indivíduos que escreveram, acidentalmente, um ou outro conto sofrível e às vezes notável. Fiz algumas descobertas. Raul Pompeia (não gosto, aliás, do Ateneu) tem um conto muito bom: "Tílburi de praça". Os contos de Medeiros e Albuquerque, em geral, não prestam; mas "O ratinho Tic-Tac" é exceção. Do Mário de Alencar descobri um conto notável, "Coração de velho". Outro esquecido, Domício da Gama, tem só um conto bom, mas é realmente bom e se chama mesmo: "Só". E quem conhece os contos de Alberto de Oliveira? Quem já leu "Os brincos de Sara"? Pois eu li e gostei. ${ }^{163}$

Vemos que Graciliano utiliza o advérbio acidentalmente para expressar sua convicção de que não há bons contistas no século XIX, exceção feita a Machado de Assis, que Graciliano faz na mesma conversa com Carpeaux, e que o fato de ter encontrado um ou outro conto bom não contraria a regra. Verdade é que o julgamento do autor de Vidas Secas, se, por um lado, atesta a pouca habilidade da quase totalidade dos escritores brasileiros com a forma do conto, por outro, deixa entrever que em alguns momentos conseguiam atingir um bom nível estético na fatura de suas obras. Em relação a Raul Pompeia, parece-nos que o julgamento talvez se baseie mais no contraste de estilos que podemos observar entre Graciliano e Pompeia, dois polos estilísticos na literatura brasileira, considerando-se a secura burocrática do estilo do autor alagoano à escritura artística a la Goncourt do escritor de $O$ Ateneu. O fato de Graciliano expressar sua antipatia pelo romance de Pompeia talvez corrobore essa hipótese. Mas o principal aqui é compreendermos que, mesmo confinados aos jornais, as obras dos escritores continuam atuando em seus sucessores, como já havíamos observado no "Plebiscito Litterario" de $1894^{164}$. Além do mais, é necessário considerar que este estudo visa analisar a forma do conto enquanto processo de amadurecimento de nossos escritores ao longo do século XIX, o que significa principalmente esquadrinhar os pontos altos que atingiram, independente da influência ou ressonância posterior que obtiveram.

163 CARPEAUX, Otto Maria. "Obras primas desconhecidas do conto brasileiro", A Manhã, "Letras e Artes”, Rio de Janeiro, 10 abr. 1949. Folha da Manhã, Quarto caderno, São Paulo, 15 maio 1949, p.14-5. Também em RAMOS, Graciliano. Conversas. Org. Ieda Lebensztayn e Thiago Mio Salla. Rio de Janeiro: Record, 2014, p.210.

${ }^{164}$ Vide capítulo 1. 
Não pretendemos tratar aqui dos processos que abarcam o conjunto dos contos de Raul Pompeia, pois já o fizemos em outro trabalho, ao qual remeto ${ }^{165}$. Ainda assim cabe dizer que durante os nove anos em que escreveu contos para os jornais, Pompeia foi um autor consciente do que produzia, procurando trabalhar a forma do conto, às vezes sob pressupostos diferentes, de maneira rebuscada e coerente, dentro de modelos específicos em uma série de contos, modelos que iam mudando ao longo das publicações. Isso significa dizer que os contos eram escritos a partir de uma forma preestabelecida pelo autor dentro de uma série, a qual finda, dava lugar a outra forma de conto. Tal processo de escrita demonstra que o autor possuía clara consciência da obra que produzia no gênero, permitindo-lhe passar por contos satíricos, românticos, naturalistas, impressionistas, realistas, contos que se aproximam do poema em prosa e contos até precocemente modernos, como "Tílburi de praça"166, como bem notara Graciliano Ramos. Essa diversidade estilística, por outro lado, jamais perde um elemento, esse, comum a todos os estilos de Pompeia no conto, que é a qualidade da síntese, trabalhada sob diversos modos. Vamos observar, através de três exemplos, como Pompeia chega a isso.

Otto Maria Carpeaux era um voraz e fino leitor. Quando a primeira tradução direta de Tchekhov para o português foi feita por Boris Schnaiderman, o crítico escreveu um artigo louvando o fato ${ }^{167}$. Nesse texto, dá uma pequena puxada de orelha numa crítica leviana que interpretava mal a influência do autor russo sobre os contistas modernos. $\mathrm{O}$ cerne da crítica abordava a questão do conto sem enredo, em que somente uma atmosfera era criada em torno de um evento, ou de nenhum. A crítica de Carpeaux procurava diferenciar o conto de Tchekhov do conto de Katherine Mansfield, a quem ele atribuía a gênese do conto sem enredo, não de forma pejorativa, pois atribuía a pobreza do conto, entre seus contemporâneos, aos maus imitadores da escritora neozelandesa. Segundo Carpeaux, o principal aspecto da arte do contista russo estava na economia de recursos que praticava.

\footnotetext{
165 SANTOS, Sidnei Xavier dos. As metamorfoses de Raul Pompeia: um estudo dos contos. Dissertação de mestrado. São Paulo: Universidade de São Paulo, 2011.

${ }^{166}$ Em relação à modernidade de "Tílburi de praça", fiz uma abordagem desse aspecto, inserindo-o numa linha tchekhoviana, no artigo "O conto esquecido pelo Modernismo: Tílburi de praça, de Raul Pompeia". Anais do X SEL Seminário de Estudos Literários "Cultura e Representação”, Assis, p.1-10, 2010. Disponível em http://sgcd.assis.unesp.br/Home/PosGraduacao/Letras/SEL/anais_2010/sidneixavier.pdf 167 CARPEAUX, Otto Maria. “Acontecimento". In.: Livros na mesa. Rio de Janeiro: Livraria São José, 1960, p.60-66.
} 
Em uma de suas cartas ao jornalista Suvorin, Tchekhov manifesta-se frequentemente sobre a técnica de sua arte. Um conto, que é por definição uma obra de tamanho reduzido, só pode dizer o que o escritor pretende dizer, mediante a mais rigorosa economia dos recursos. Embora dramaturgo de gênio, Tchekhov evita em muitos contos seus o diálogo. Mas quando o diálogo lhe parece importante, então dá quase só diálogo, omitindo as descrições, etc. ${ }^{168}$

Mais à frente Carpeaux vai reiterar que o conto de Tchekhov em nenhum momento deixará de possuir um enredo, mas que este é apenas reduzido ao que tem de essencial, mesmo que o essencial seja algo ao qual não se dá grande importância, como é o caso do conto "Um acontecimento", que ele analisa, mostrando que o acontecimento do título é absolutamente irrelevante para as personagens da história, pois o cotidiano lhes tornou insensíveis perante a possível brutalidade da morte de três gatinhos comidos por um cão terrível. O acontecimento aqui é a revelação chocante que as crianças do conto adquirem sobre a verdade da vida, que é a naturalidade estulta da morte. Não há mais história que isso, simplesmente porque não é necessária. A arte de Tchekhov, conquistada no decênio de 1880 numa Rússia czarista, é esta, a de mostrar apenas o que é fundamental ao conhecimento da vida, mesmo que seja um conhecimento trágico, por isso o conto se despe de tudo o que é acessório, menos, evidentemente, do enredo, segundo Carpeaux, que faz questão de enfatizar que os contos do autor russo possuem enredo, diferente dos de Katherine Mansfield. A técnica do dizer menos é curiosamente a chave do mostrar mais.

Raul Pompeia jamais leu Tchekhov. Descartemos qualquer consideração nesse sentido. Não há, portanto, influência ou apropriação de um pelo outro. A presença aqui do autor russo tem a ver com uma técnica de conto que Pompeia esboçará no primeiro texto do gênero que publica, em 1881. Repito que a similaridade está apenas na técnica, uma vez que o estilo e a temática dos autores diferem muito. Pela lição de Flaubert, de quem criticava o excesso de descrições, Tchekhov será adepto do uso parco de adjetivos, enquanto Pompeia, por influência da escritura artística dos irmãos Goncourt, será um adjetivista contumaz. Se há no autor russo certa melancolia em suas histórias, não raramente elas são permeadas por um humor sutil e conformado, enquanto o brasileiro tem, em geral, um olhar trágico e cruel sobre a vida, exceção feita a poucos contos. Exceção que é o caso deste primeiro, "Como nasceu, viveu e morreu a minha inspiração", em que um leve humor e resignação o aproximam dos contos mais humorísticos de

\footnotetext{
${ }^{168}$ CARPEAUX, p.62.
} 
Tchekhov, como por exemplo "Bilhete premiado", de 1887, ou "A morte do funcionário", de 1883, em que, a par dos pouquíssimos fatos realizados na história, tem-se um retrato bem humorado dos tipos comuns de uma sociedade russa no século XIX. Talvez este também seja um dos contos de Pompeia que mais se aproxime de uma atmosfera machadiana, no sentido do humor e da ironia típicos desenvolvidos pelo autor do Cosme Velho na mesma década de 80 , em seus romances e contos. Retomamos aqui o conto para um olhar mais estrutural ${ }^{169}$.

Em sucintas palavras o narrador está em seu quarto de estudante à espera da hora do baile, em que pretende ver sua amada que está completando dezessete anos. Como há ainda muitas horas até a festa, precisa fazer algo para matar o tempo. Arruma-se, transita pelo quarto, olha a janela. Enfim, resolve escrever um soneto como presente para a amada. Ao empunhar a pena, uma gota de tinta lhe mancha o punho da camisa branca, a única que possuía. Frustrado pelo acidente, decide não ir à festa. Posteriormente, saberá que a moça dançou com outro rapaz, com quem veio a se casar. Há, de fato, muito pouco a resumir em relação ao conto. Podemos ainda resumir mais: o estudante aguarda o horário da festa; um acidente com sua única camisa a inutiliza; ele decide não ir à festa. Se retomarmos as noções de Friedman ${ }^{170}$, vemos que Pompeia trabalha todo o conteúdo do conto em torno de um único episódio, que é a desistência em ir à festa. A economia de recursos aqui é um grande desafio, pois envolve duas linhas contrastantes: a primeira é que algumas horas separam o estudante do baile; o conto inicia ainda à tarde, na hora do jantar, provavelmente não muito além das 14 horas, e o baile, com sua respectiva ceia, aconteceria por volta de 21 horas $^{171}$. A segunda linha é que, durante esse tempo, praticamente nada acontece. De que modo Pompeia consegue resolver isso?

O conto trabalha com uma alternância dinâmica entre as reflexões do narrador, que imagina as felicidades com a moça mais tarde, assim como projeta a realização de seu soneto, com ações que visam a demonstrar a passagem do tempo, mas expressas de forma extremamente econômica, às vezes com um único verbo: "Preparei-me.

\footnotetext{
${ }^{169} \mathrm{Na}$ dissertação de mestrado, em seu segundo capítulo, o conto é analisado detalhadamente. No entanto, naquele trabalho, o intuito foi mostrar como Raul Pompeia, neste conto, utiliza a ironia subjacente do narrador para provocar uma inversão dos termos românticos presentes na história, de modo a desconstruir, logo em seu conto de estreia, qualquer visão romântica que se quisesse ter do conto. Ver SANTOS, op. cit. 2011, p.28-39.

${ }^{170}$ FRIEDMAN, Op. cit., 2004.

${ }^{171}$ Para os costumes e hábitos do século XIX ver Vida cotidiana em São Paulo no século XIX: memórias, depoimentos, evocações. Org. de Carlos Eugênio Marcondes de Moura. São Paulo: Ateliê, 1999.
} 
Empomadei-me; escovei-me; perfumei-me; mirei-me, etc" ${ }^{172}$, que fazem com que o tempo da história flua rapidamente sem estender o tempo da narração. Após se arrumar devidamente, como mostra o trecho acima, o narrador nos diz que eram "cinco horas" e que "não queria chegar antes das sete" com a intenção de fazer-se "um pouco desejado", mas ainda precisava passar por "duas longuíssimas horas"173. A solução ele mesmo nos dá ao descrever seu quarto desarrumado de estudante, sem se alongar muito, pois também não havia tanto o que descrever. Feito isso, vai à janela para olhar vagamente qualquer coisa. É interessante notar que aqui se poderia encontrar um motivo na rua de distração, passando com isso algum tempo a narrar ou descrever o que se via fora do quarto, matando o tempo da história e movendo à frente o tempo da narração. No entanto, o olhar do narrador em nada se fixa, pulando de uma coisa à outra sem atenção alguma, apenas vagando:

Meus olhos corriam pela rua como andorinhas brincalhonas. Depois de percorrerem o quarto, andavam pela rua em busca de uma resposta à minha pergunta: - que fazer?...

Por fim foram esbarrar no frontispício da igreja de ... Começaram a subir... Brincaram nas janelas; contaram quantos vidros havia; examinaram os enfeites de arquitetura... Subiram mais, percorreram os sinos, o zimbório e foram pousar no para-raios.

Estavam quase no céu. Daqui para ali, menos de um passo. Os olhos lá foram. Mergulharam-se erradios no azul... Que fazer? ${ }^{174}$

As orações são curtas, os verbos acumulando as ações, que fazem o tempo passar sem darmos por isso. Quanto tempo ali correu? Para o leitor, certamente muito pouco. Para o estudante, cuja distração se inebriava na própria falta de foco, também não deve ter durado muito. Mas para a história, tempo suficiente para fazer a ação adiantar-se. Pompeia, apesar de seu estilo, pictórico muitas vezes, atinge uma eficácia extraordinária no trecho. Vence horas com poucos recursos, suficientes apenas para se chegar ao que interessava. Em seguida, o narrador se concentra em uma cena, pois the veio a ideia que tanto esperava para que o tempo escoasse rapidamente. Em um trecho afetadamente romântico nos dá a resposta que procurava:

Ora... enfim! Estava achada a resposta! Por que não veio ela mais cedo não o posso explicar.

Os meus olhos estavam no céu.

\footnotetext{
172 POMPEIA, Raul. Contos, p.19.

${ }^{173}$ Idem, p. 19.

${ }^{174}$ Idem, p. 20.
} 
Era por uma tarde encantadora. Que cor a do firmamento nessa hora! Que abóbada incomparável a cobrir a rua!... Depois, aquelas nuvens mimosas, desfiando-se nos ares, como brancas meadas de lã nuns dedos sedutores... $\mathrm{O}$ sol a descambar, batendo de través na poeira levantada do chão pelos carros, que magníficas cortinas desdobravam pelas janelas das habitações velando-as como que de douradas gazes. No horizonte, por sobre a última linha de telhados e chaminés fumegantes, como se ostentavam aquelas colinas de um azulado branco feitas vapores tênues; como se recortavam sem fazer uma só volta que não fosse demorada e graciosa como as curvas de esbelto corpozinho de donzela...

Oh! Do quarto para fora, tudo o que se prendia aos céus por um raio de luz ou por uma ponta de vaporoso véu, tudo respirava poesia...

Eu achara a resposta. Que fazer?... Versos!... Feliz achado!...Um soneto ou alguns alexandrinos... qualquer cousa que desse claro testemunho do meu amor. ${ }^{175}$

A alternância no conto entre ações muito rápidas, que fazem o tempo da história avançar, e reflexões estendidas, que atrasam essa passagem, provoca um resultado de extrema efetividade em termos de economia. Por um lado, acompanhamos a angústia do estudante com o baile que não chega, mas por outro, talvez muito mais importante, é possível ver a nu, porque sobra tempo para isso, o comportamento romanticamente estereotipado do narrador, que se revela sem necessariamente ter a plena consciência do que diz de si mesmo ${ }^{176}$. Nesse conto, Pompeia manipula habilmente o tempo da história, estendendo e contraindo o tempo da narração conforme o objetivo a ser mostrado a cada momento e principalmente a meta a ser alcançada, que é a de sentirmos o drama do estudante, um pouco desconfiados da verdade de seus sentimentos. O tempo estendido das reflexões dá a entender que o soneto frustrado pesou mais que a perda da moça para um rival, fato contado em poucas linhas ao final do conto. Nada mal para um escritor que nem completara 18 anos.

Ao fim do mês de abril de 1881, mesmo em que Pompeia estreara no conto, o autor passa a publicar no mesmo jornal uma pequena série de três contos intitulada "Microscópica", que saem nos dias 27 de abril, 13 de maio e 21 de maio, "Niente", "Milina e Turco", "Antes e depois", respectivamente. Em comum, além do título que os

\footnotetext{
175 Idem, p. 20.

${ }^{176}$ Afirmo, na dissertação, tendo em vista o estatuto do narrador: “Assumindo esse tom íntimo, o narrador poderá, em diversos momentos, interromper a sequência dos fatos, que por si não são numerosos, para divagar, exclamar impressões, dialogar com o leitor que projeta. Há, entretanto, nesse narrador, algo que parece inadequado, que cria um descompasso entre os fatos narrados e linguagem que os recria, que, de forma insidiosa, penetra na narração, corrompendo-a a partir de dentro e lançando uma nuvem de desconfiança sobre o próprio narrador". SANTOS, op. cit., p.31.
} 
encima ${ }^{177}$, os três têm a brevidade como característica principal. O primeiro, "Niente", apresenta o episódio do roubo de um botão de rosa por um rapaz enamorado da protagonista, a mocinha Elvira. Em seis rápidas cenas, o narrador mostra o cuidado da moça com aquela roseira prestes a florescer, pois pretende dali tirar uma flor para seu amado, que se antecipa e colhe secretamente a rosa antes da moça, que se aborrece com o trabalho frustrado, até que o moço apareça com o produto do furto. Mero retrato delicado de uma situação romântica, o pequeno conto tem a qualidade de, apesar da ambientação poética, que Pompeia depois desenvolverá nas Canções sem metro, sintetizar em brevíssimas cenas uma determinada situação.

No conto seguinte, "Milina e Turco", o triste episódio da vida de uma menina pobre, ainda num ambiente fortemente romântico, com a imagem antagônica do Bem e do Mal representados pela menina e a boneca de um lado e pelo cão e o menino rico de outro, é mostrado em cinco cenas, quatro delas bastante reduzidas. A menina Emília, protegida de uma senhora de caráter duvidoso, larga sua boneca de trapo, Milina, no chão do cortiço enquanto vai ajudar a tal senhora, caída entre "panos escuros e imundos, cheirando a vinho" 178 . Ao voltar com a água para sua senhora, o cão negro do filho do sr. Visconde tem a boneca na boca. A menina avança sobre o cão, mas é repelida pelo garoto, que lhe fustiga o rosto com um chicote, cegando-a. Reparemos como o narrador constrói a oposição entre as duas personagens com duas pequenas cenas e já as coloca em confronto na brevíssima cena seguinte:

II

Emília, descalça, saiu da estalagem correndo, com um regador amarrotado e ferrugento. Era tão grande para ela o regador que ia roçando pelos lajedos. Ia buscar água para a pocilga da senhora que a protegia.

E Milina?... Pobre Milina! Emília havia de lhe pedir perdão por tê-la deixado só, naquela hora que era a única em que a coitada dormia no colo de mamãe...

III

Um belo cão negro enfeitado de bastos pelos reluzentes, orgulhoso em extremo, espécie de cão fidalgo, entrou pelo cortiço, com a cauda enroscada em penacho e as orelhas erguidas. Logo depois voltou, atirando ao ar as grandes patas, saltando alegre. De vez em quando, sacudia o focinho e via-se alguma coisa a balançar pendente. A pouca distância, o dono do cão, o filho do sr. Visconde, pequenote, de calças curtas ainda, e já pelintra, soltava largas

177 “Antes e depois" traz outro título, "Uma história por dia”, o que não significa que seja de fatura diferente dos demais.

${ }^{178}$ POMPEIA, Contos, p. 25 . 
risadas, batendo com o pezinho bem calçado na soleira de mármore do palacete da família. Com um chicotinho fino fustigava o ar e ria-se... ria-se...

IV

Emília vinha da bica da esquina, arrastando o regador cheio a transbordar.

Aquele cachorro!...

Ao chegar à porta da estalagem viu o cão.

O animal galopava para o palacete e levava Milina nos dentes.

Emília fora de si atirou o regador, que tombou na sarjeta e voou sobre o animal... ${ }^{179}$

A cena IV, por exemplo, possui uma dinâmica extraordinária, quase cinematográfica, menina e cão alternando-se na imagem construída, reforçando a ideia de oposição, em que os cortes têm a propriedade de acentuar o dramatismo da cena, preparando o desfecho cruel que o conto terá com a cegueira da menina. A economia, bem utilizada, cumpre um papel primordial para o objetivo da história, de um certo maniqueísmo romântico, possivelmente, mas de grande êxito em sua diminuta funcionalidade.

No terceiro conto da série, "Antes e depois", a mais curta das três, curiosamente é a que tem a história mais longa, que abrange alguns anos, pois narrará o amor entre Belmiro e Clara, do namoro ao fastio do casamento. Cinco cenas, todas sintéticas, cada uma apresentando um aspecto da história do casal. A primeira apresenta os dois enamorados na casa do desembargador, pai de Clara; a segunda mostra os dotes musicais de Clara, que encantam Belmiro. A terceira, no entanto, quebra todo o clima romântico de então, de modo sucinto e direto, com palavras colocadas nos lugares certos e um hiato de tempo providencial:

III

Rola o tempo...

Numa casinha modesta de S. Cristóvão, mora o dr. Belmiro com sua senhora d. Clara... Os vizinhos dizem coisas...ih! ${ }^{180}$

E é isso toda a cena. Três orações que utilizam o tempo presente com o sentido de algo frequente e habitual. Há uma sugestão de passagem implacável do tempo, destruidor de qualquer fantasia romântica, reforçada pela "casinha modesta" do casal, que certamente tivera sonhos maiores, mas principalmente representado pela ação

\footnotetext{
${ }^{179}$ Idem, p. 25 .

${ }^{180}$ Idem, p. 28 .
} 
coadjuvante e maledicente da vizinhança, que sacramentam o esfacelamento progressivo do amor romântico vislumbrado no início do conto. As duas últimas cenas fazem o contraponto das duas primeiras. Na penúltima, sabemos que o marido está endividado e sem o dote de sua esposa; e na última, todo o encanto e amor entre os dois se perdeu frente à realidade, e a música que encantava o marido agora o atormentava. Não há espaço para mais nada, e nem necessidade de se dizer algo mais. A casa romântica está em ruínas, apodrecida a partir de dentro, corrompida de realidade. A série "Microscópica" será ainda repetida em outros momentos, em 82 e 83, em outros jornais, e sua lição de síntese será retomada em outra série chamada "Contos domingueiros", no Jornal do Comércio, em 83, e nos contos publicados em A Rua, já em 1889, com uma forma literária mais aprimorada, como mostra o conto "Tílburi de praça". Mas vamos a um exemplo diferente de síntese que Pompeia pratica em um conto bastante incomum publicado na Gazeta da Tarde do Rio de Janeiro em 26 de dezembro de 1885, chamado "50\$000 de gratificação".

O texto tem como ponto de partida um anúncio de jornal, em que é divulgada a fuga de um escravo e é oferecida uma gratificação, daí o título do conto, a quem o capturar. O início, incomum certamente, tem a propriedade de, como um pequeno resumo, antecipar toda a história do escravo referido, chamado Lino, sem a necessidade de uma narração mais delongada que contextualiza o leitor de quem é o escravo, de onde e como fugiu, até o momento em que o anúncio vem a ser publicado. O anúncio economiza toda a história pregressa de Lino em poucas linhas, sem a necessidade de qualquer outro elemento. Mais que isso, também nos fornece algumas informações singulares para formarmos uma imagem desse escravo fugido, além do comum para um anúncio desse tipo, em que a figura humana é descrita de forma próxima a de um animal. Como exemplo, vejamos os anúncios abaixo: 

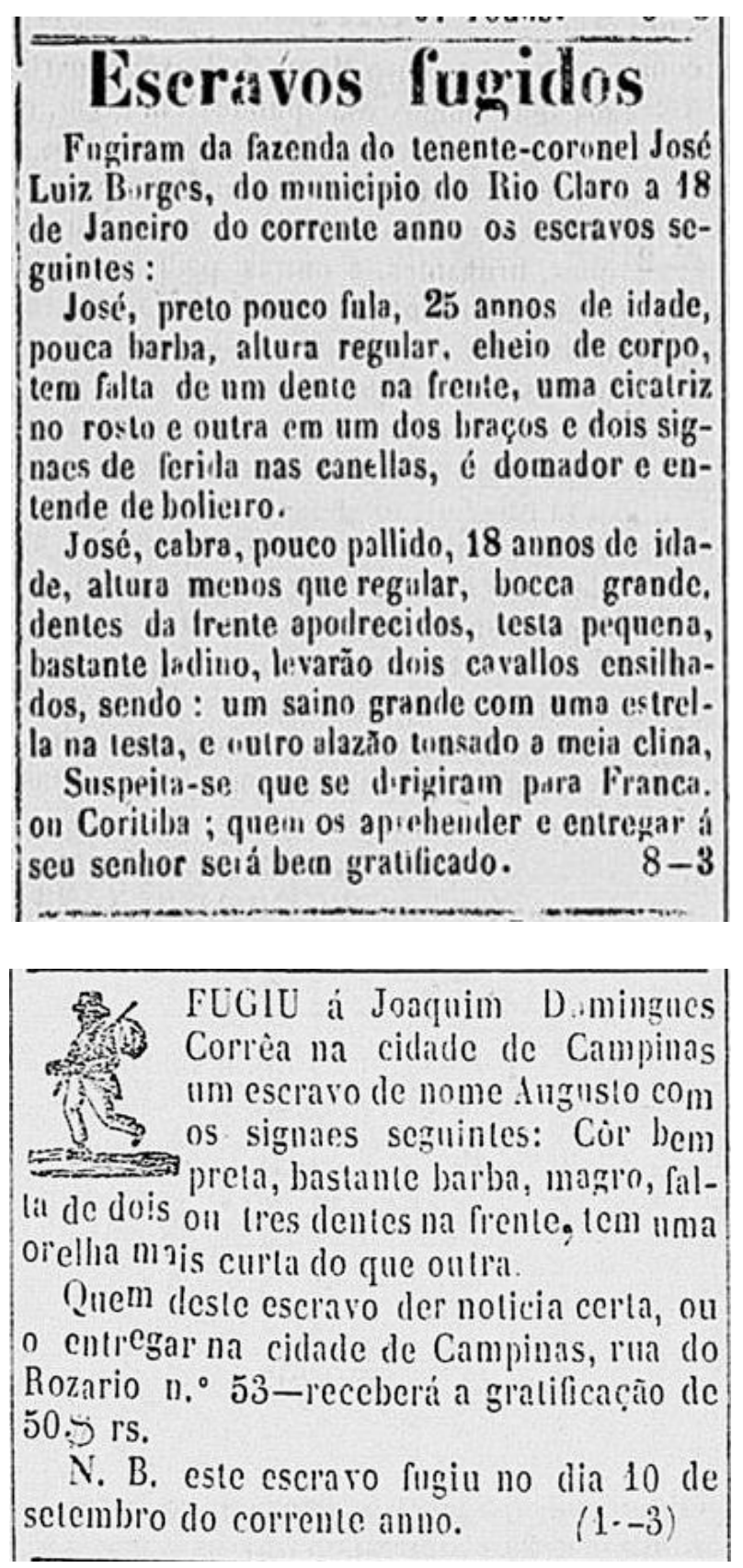

Ambos os anúncios procuram se restringir às características físicas dos escravos fugidos, a se reparar os sinais de violência e maus-tratos a que eram submetidos, com suas cicatrizes no corpo, feridas nas pernas, ausência de dentes ou dentes apodrecidos e uma orelha mais curta que a outra. Eram anúncios frequentes nos jornais da época ${ }^{181}$, e Pompeia se utiliza do gênero para a elaboração de seu conto, que, carregado de ironia e sátira, inverte a relação de poder que tais anúncios pressupunham entre o senhor e seu escravo. Abolicionista engajado, corajoso nas atitudes e provocações que fazia à

${ }^{181}$ Para visão mais detalhada sobre o assunto, ver a excelente abordagem de Gilberto Freire em $O$ escravo nos anúncios de jornais brasileiros do século XIX. 4ª ed. São Paulo: Global, 2010. 
hipocrisia dos escravocratas liberais brasileiros ${ }^{182}$, Pompeia cria uma peça única de crítica social com este pequeno conto.

A história em si nada mais é que a resposta redigida pelo escravo ao anúncio de sua própria fuga. Nessa resposta, endereçada ao anunciante, o escravo fugido, Lino, comenta o conteúdo do anúncio original, concordando com a descrição que é feita de sua pessoa em alguns momentos, em outros, discordando, certamente os que lhe pintam de forma depreciativa, como quando falam de que tem dentes maltratados ou de que é atrevido, termo que, colocado no anúncio, prenuncia um aspecto do caráter da personagem, o que não vimos nos outros anúncios de fugitivos anteriores. O tom é sempre o da ironia, principalmente considerando-se que agora Lino é um homem livre do jugo de seu senhor. O começo da resposta é um primor de cinismo:

Mirando-me ao espelho, reconheci, no frontispício da minha obscura cabeça, os vigorosos traços descritivos, com que encheu este anúncio a pena abalizada do seu anônimo e simpático escritor. Linha por linha, incidente por incidente, lá vem a minha fotografia. Isso não é um anúncio, é um retrato! Mirando-me ao espelho e no anúncio, entrei a hesitar, até, sem saber qual dos dous era o anúncio e qual era o espelho... ${ }^{183}$

Note-se, fundamentalmente, a linguagem alambicada e pernóstica da resposta, que intenta, com sua fingida nobreza, expor a liberalidade de pensamento e expressão da qual o ex-escravo agora é possuidor, porque não tem mais dono. Ao antigo silenciamento de homem escravizado, tem Lino agora a total liberdade de dizer o que quer e como quer, sem as correntes que lhe tolhiam a voz. O conto é, também, um exercício provocativo de cinismo, em que a prerrogativa de superioridade atribuída ao autor do anúncio é invertida pelo escravo eloquente e atrevido. Linha a linha ele vai respondendo, com frases curtas e bem-humoradas, o conteúdo do anúncio. À expressão "é muito conhecido", responde com uma pérola de exagero cômico, como se esfregasse aos olhos do antigo senhor a sua grandeza açoitada pela escravidão:

\footnotetext{
182 Afonso Schmidt é quem relata, referindo-se ao ano de 1882, tendo Pompeia apenas 19 anos: “Assim, Raul teve de abandonar São Paulo, para ele povoado de boas e más recordações. Antes da partida, porém, nos meses que aqui permaneceu, dedicou-se a burilar teimosamente as 'Canções sem metro', a levar aos extremos a sua obra republicana e abolicionista. Deu provas de exaltada coragem. Basta lembrar que, numa excursão pelo Interior, falando naquela assembleia de escravocratas em que se propôs aceitar a República, sob a condição dela conservar o regime escravista, o escritor em seu discurso respondeu-lhes frontalmente: - Senhores fazendeiros! O vosso barrete frígio não passa de um saco de coar café!"'. In.: O Canudo: Raul Pompeia em São Paulo. São Paulo: Clube do Livro, 1963, p.61.

Aos fazendeiros liberais e escravocratas, Raul Pompeia reservará a sátira contundente do conto "14 de julho na roça", publicado no ano seguinte, em 1883, na Gazeta de Notícias do Rio de Janeiro.

${ }^{183}$ POMPEIA, Contos, p.155.
} 
Exatamente! Sou muito conhecido. O Larousse cita-me o glorioso nome, no volume da letra L. E com razão! Eu guiava certo as minhas parelhas, em direção à Posteridade, quando a conveniência urgente de tomar ares obrigoume a cortar a bela carreira. Apesar disso, o anúncio não mente. Sou na verdade conhecido, sou um homem universalmente popular! Dou-me muito com o Pão de Açúcar; o Corcovado fala comigo; já tive estreitas relações com o Himalaia; a coluna Vendome, quando me vê, cumprimenta-me; as pirâmides tiram-me o chapéu; as esfinges já me ofereceram cigarros uma vez; os crocodilos da Índia têm sorrisos amáveis para mim, pedem-me fogo com intimidade...Quanto aos homens, não falemos. $\mathrm{O}$ meu nome monopoliza perpetuamente a atenção do público, no Cairo, em Malta, em Nazaré, no Egito... ${ }^{184}$

Há um requinte no trecho. Todo ele expõe uma erudição de enciclopédia que, dado o acúmulo, tem função humorística, como vimos anteriormente na análise do conto " $\mathrm{O}$ imortal", de Machado de Assis. O escravo satiriza esse conhecimento tipicamente presente nas moradias burguesas, como inteligência de prateleira, ao mesmo tempo que se põe acima dos senhores que o escravizaram, em virtude de uma fama que nenhum outro teria. Lino não é só atrevido, é também perspicaz no modo como observava, do seu lugar rebaixado, a grandeza vazia dos senhores brancos. Ao final de seus comentários, Lino esclarece ao leitor que o anúncio chegara casualmente em suas mãos, o que lhe despertou "saudades do Rio de Janeiro", em outra desfaçatez provocativa. Mas o motivo da resposta que manda ao jornal é de outra ordem, uma vez que visa ao montante oferecido como recompensa. Novamente a inversão se torna clara, dada em poucas linhas, de forma direta, propondo que lhe fosse entregue ao menos metade da gratificação oferecida, já que ele mesmo estava dando informações de seu paradeiro na serra de Baturité, no Ceará. $\mathrm{O}$ atrevimento não podia ser maior: estou aqui e quero ver quem me pega.

Há um detalhe a mais importante nesse texto. Pompeia mistura gêneros, assim como ao longo de sua carreira misturou estilos. O anúncio tem uma carta como resposta, e isso forma o conto. Mas além desse detalhe, que por si já demonstra, considerando a maneira como Pompeia manipula esses gêneros, a habilidade do escritor, o texto finaliza com uma espécie de apêndice, incorporado ao todo do texto, mas aposto a ele, como um post scriptum, em que se modifica o narrador. Nesse caso, seria o próprio redator do jornal, que contextualiza tanto a origem da carta quanto do anúncio. O procedimento dá ao conteúdo anterior um peso de verdade que não possuiria se fosse lido apenas como uma história de ficção, que verdadeiramente é. Ou, e é possível que isso faça parte do

${ }^{184}$ Contos, p. 156. 
jogo de Pompeia aqui, talvez não o fosse. O fato é que o suposto post scriptum do redator reforça o aspecto de verossimilhança que o conto necessita, já que seria possível duvidar que um ex-escravo, mesmo alfabetizado, pudesse apresentar uma linguagem tão rebuscada como a de Lino, mesmo tendo sido ele "cocheiro do Dr. Peçanha". Outro detalhe é perceber que também o redator deixa escapar sua ironia em relação ao anúncio, colocando-o no patamar de outras publicações clandestinas não muito celebradas socialmente:

O referido anúncio é um avulso que se distribuiu há tempos, nesta cidade, sem responsabilidade do autor, sem declaração de tipografia, à maneira desses pobres papéis pornográficos impressos que conhecem o seu estado e não o lamentam como Nise ${ }^{185}$.

Embora nem sempre Raul Pompeia tenha conseguido manter em seus contos a mesma qualidade, pois alguns se ressentem de um fatalismo exagerado de raiz romântica e se deixam às vezes impregnar de um sentimentalismo verboso, o autor soube, em geral, manipular expressivamente a propriedade de síntese neles. Talvez por seu temperamento polêmico e sempre disposto ao debate, o que lhe será fatal biograficamente, não tenha dado ao gênero maior atenção que o seu gênio e habilidade certamente lhe permitiam. A contenção do conto talvez o enervasse. Ou talvez, como uma espécie de terapia, o acalmasse. Sua escolha de não mais escrever contos a partir de 1890, cinco anos antes de seu suicídio, certamente entra para o rol de renúncias literárias com as quais frequentemente nos deparamos.

Mas, se Raul Pompeia, talvez pelo temperamento, nos apresenta um estilo rebuscado e inflamado de imagens e figuras, o seu antípoda não poderia ser outro senão Lúcio de Mendonça, autor de "sobriedade vigorosa"186, de estilo contido e elegante, que certamente nos deu um outro modo de olhar para o homem do interior, menos tipológico e pitoresco, como faziam os românticos, e certamente menos folclórico ${ }^{187}$. Embora

\footnotetext{
185 Contos, p.157. Nise, provavelmente, era a musa dos poemas do árcade Cláudio Manuel da Costa (17291789).

186 Cf. nota 119.

187 Alexandre Eulálio afirma o seguinte em relação ao regionalismo de Lúcio de Mendonça: "Desta experiência cotidiana da roça provieram algumas das suas melhores histórias. 'João Mandi', 'Mãe cabocla', 'Coração de caipira' (a última datada de 1877) são na realidade, que se saiba, os primeiros contos rústicos de nossa literatura que valham por si mesmos - se se quiser, os nossos primeiros contos 'regionais' -, e não interessam apenas pelo vago colorido documentário dos poucos românticos que os antecederam. [...] o caipira de Lúcio de Mendonça não pretende expressar certo e determinado meio geográfico ou o homem definido por uma tal relação mesológica." O trecho pertence ao artigo "O último bom selvagem: "Luís da Serra', de Lúcio de Mendonça”. In.: Tempo reencontrado: ensaios sobre arte e literatura. Organização e apresentação Carlos Augusto Calil. São Paulo: IMS/Editora 34, 2012, p.61.
} 
exilado no interior de Rio e Minas Gerais, em função do trabalho jurídico, desde 1877, quando se forma na Faculdade de Direito de São Paulo, até 1888, quando retorna ao Rio de Janeiro, Lúcio irá produzir nesse tempo a maior parte do que depois irá compor o volume de contos Esboços e perfis, publicado em 1889. Seu conhecimento íntimo do homem do interior - até os 13 anos, Lúcio morou em uma fazenda em São Gonçalo do Sapucaí, MG - lhe permitiu uma visão mais direta e menos idealista da personalidade rústica, palavra que Alexandre Eulálio ressalta ${ }^{188}$, da gente de fora do grande centro que era a Corte. Órfão de pai muito cedo, aos 4 anos, foi criado por um parente após o segundo casamento de sua mãe, quando ainda tinha 5 anos. Aos 14, foi morar em São Paulo junto a seu irmão, Salvador de Mendonça, 13 anos mais velho e já estabelecido. Autodidata em vários aspectos e certamente tendo uma visão pragmática da vida, Lúcio também se embebeu do romantismo reinante naquele momento, o que seu primeiro livro de poemas, Névoas matutinas (1872), prefaciado por Machado de Assis, irá mostrar ${ }^{189}$. No entanto, seu segundo livro de poemas, Alvoradas, três anos depois, já terá diversos poemas de temática social, mostrando a maturidade pessoal e literária que o ainda rapaz Lúcio vinha adquirindo. Seus primeiros contos de Esboços e perfis datam dessa época, 1875, e já vão mostrar um escritor que, se ainda estava em transição ${ }^{190}$, já possuía um sentido de estilo e forma um tanto diferente de seus contemporâneos.

A escassa crítica sobre os contos de Lúcio de Mendonça salienta a sobriedade de seu estilo. Raimundo Correia (1859-1911), o poeta parnasiano, do qual me permito reproduzir um longo trecho do que escreveu, dados a relevância das comparações que faz e o estado precário em que se encontra o jornal de onde se extraiu o texto, diz o seguinte, ainda antes de Lúcio ter lançado o primeiro volume de seus contos:

Mas é como prosador principalmente que, com melhor realce, se distinguem a individualidade, o temperamento, o poderoso gênio e os inestimáveis predicados do escritor castiço.

Tende à vista os seus artigos de crítica literária, os seus romances, os seus mais ligeiros contos, como o "João Mandi", publicado, há poucas semanas, na Gazeta de Notícias ${ }^{191}$; seus contos, sobretudo, são verdadeiras páginas de mestre, notáveis pela profundeza da observação e, ainda mais, pela excelência da forma, onde se acham caprichosa e primorosamente fundidos.

\footnotetext{
188 Idem.

${ }^{189}$ Para as informações biográficas sobre Lúcio de Mendonça, ver MENDONÇA, Edgar e Carlos Sussekind de. Lúcio de Mendonça: ensaio bio-bibliográfico. Rio de Janeiro: Civilização Brasileira, 1934.

190 "Escritor de um período de transição - transição em todos os campos e setores - Lúcio de Mendonça mantinha-se fiel ao mesmo tempo ao passado e ao presente”. Cf. EULÁLIO, op. cit., p,80.

191 “João Mandi” foi publicado na Gazeta de Notícias em 17/04/1887.
} 
Neste gênero, os que têm competido com Lúcio de Mendonça, não se considerariam avantajados a ele.

Faltar-lhe-á talvez esse escrúpulo da exatidão minuciosa de que dispõe Aluísio Azevedo, o maior dos nossos romancistas contemporâneos; o autor do Mulato e da Casa de pensão não pinta somente; para melhor dizer: daguerreotipa.

Valentim Magalhães possui uma extraordinária palheta, rica de cores rutilantes e quentes; seus quadros têm uma vivacidade particular que os ilumina e que nos de nenhum outro autor se nota. Raul Pompeia é um pintor extremamente original e delicado; os fatos que descreve, ele os encara só pelo lado que, primeiro, fez impressão em sua fina sensibilidade artística, e, muita vez, para suavizar-lhes o realismo bárbaro, os apresenta esfumados e velados como por um discreto nevoeiro diáfano e louro; as meias tintas de que usa são um segredo incomunicável, exclusivamente seu, próprio da sua natureza.

Lúcio de Mendonça, entretanto, na generalidade de seus traços, toca o que é essencial para caracterizar os personagens que exibe, apanhados de perfil apenas; e por um só gesto, uma só frase, um só movimento, os descobre [...] ante o leitor, com máxima fidelidade, exatos e verdadeiros.

(...)

No que, então, nenhum dos nossos escritores o excede é na parcimônia regrada dos vocábulos e na admirável propriedade com que os distribui. ${ }^{192}$

Vamos destacar alguns pontos do texto de Raimundo Correia, uma vez que são reiterados por outro críticos, como veremos, e expressam uma característica que, no caso de Lúcio de Mendonça, o diferenciará de outros autores de forma positiva, já que perceberemos que exatamente dessas qualidades é que sua prosa se utiliza para dar forma expressiva a seus contos. Mais ainda, que a análise de Correia opõe Lúcio a outros autores, notadamente em termos de estilo, apesar dos três autores citados também terem estilos bastante diferentes entre si. No entanto, os três se colocam em um polo contrário ao de Lúcio, o primeiro em função de seu detalhismo naturalista, o segundo, por conta de seu cromatismo intenso e variado, e Pompeia, nas palavras de Raimundo Correia, por um impressionismo artístico bastante particular.

O primeiro aspecto a ressaltar em Lúcio de Mendonça é o de um escritor de estilo contido, econômico, que as expressões "escritor castiço", "parcimônia regrada dos vocábulos" e "um só gesto, uma só frase, um só movimento, os descobre" procuram traduzir. É de se chamar atenção para esse elemento, por se considerar que a prática então dos escritores, provavelmente de raiz romântica por um lado, como já vimos no primeiro capítulo, mas também de extração naturalista, no que toca ao detalhamento descritivo, era

192 "Lúcio de Mendonça”. A Semana, 21/05/1887. Algumas lacunas do texto do jornal foram resolvidas com parte da citação encontrada em Lúcio de Mendonça: o homem e a obra. Organização de Eliana de Mendonça Penafiel e Orlando Meirelles Padilha. Rio de Janeiro: O. Meirelles Padilha, 2004, p.29. 
a de uma escrita minuciosa e prolongada, no sentido de não economizar palavras até o momento em que a expressão não estivesse plenamente satisfeita, ou que a verossimilhança, principalmente aquela ligada ao referente, o exigisse. Já não era esse o caminho de Machado de Assis, e não seria também o de Lúcio de Mendonça, exceção feita ao conto "Luiz da Serra", publicado já no final do século na Gazeta de Notícias ${ }^{193}$, como bem lembra Alexandre Eulálio em sua análise ${ }^{194}$. A característica é reforçada quando Correia compara Lúcio a Aluísio Azevedo, dizendo que lhe faltava (a Lúcio) “esse escrúpulo da exatidão minuciosa" que sobrava ao outro. Não deve parecer estranho que um poeta parnasiano como Raimundo Correia, que elogia Lúcio por sua "excelência da forma", ao mesmo tempo se ressinta da falta de detalhismo do contista. Lembremos que o parnasianismo no Brasil se diferenciou de sua fonte francesa por um rebuscamento excessivo, que Manuel Bandeira classifica como de "caráter escultural"195. Também é curioso que ao detalhismo de daguerreotipo de Azevedo, o poeta junte a "extraordinária palheta" de Valentim Magalhães e o "realismo bárbaro" de "meias tintas" de Raul Pompeia. Ao fim, os três exemplos escancaram a diferença entre Lúcio e os demais no que toca às questões de economia de palavras, de contenção narrativa e de busca da síntese e da concentração. Para Correia, o prosador foca no que é "essencial", facilitandolhe um olhar de profundidade sobre suas personagens; por um lado, sua grande qualidade, por outro, motivo da ressalva.

É possível relacionar a crítica de Raimundo Correia ao momento em que escreveu, no sentido de observar em sua análise que ela se suporta sobre uma base cientificista bastante difundida e praticada no Brasil da época, cujo maior escritor, ainda segundo Correia, era Aluísio Azevedo. Auerbach produz um retrato fiel desse momento na França, que era a fonte de modelos para os escritores brasileiros, quando escreve sobre Germinie Lacerteux, dos irmãos Goncourt:

O romance [a partir dos Goncourt] teria ganho em amplitude e importância, seria a forma séria, apaixonada, viva do estudo literário e da pesquisa social (...); tornar-se-ia, pelas suas análises e investigações psicológicas, uma Histoire morale contemporaine; ter-se-ia imposto os métodos e os deveres da ciência e poderia também, portanto, reivindicar os seus direitos e as suas liberdades. Fundamenta-se, aqui, o direito de tratar qualquer objeto, mesmo o mais baixo, de forma séria, isto é, a extrema mistura de estilos, simultaneamente com argumentos político-sociais e científicos. A atividade

\footnotetext{
193 O conto sairá em 1897, depois republicado na coletânea Horas do bom tempo, em 1901.

${ }^{194}$ EULÁLIO, op. cit.

${ }^{195}$ BANDEIRA, Manuel. Apresentação da poesia brasileira. São Paulo: Cosac Naify, 2009, p.102.
} 
do romancista é comparada com a atividade científica, sendo que, com isto, indubitavelmente se pensa em métodos biológico-experimentais ${ }^{196}$.

Reparemos que o método científico tem uma pretensão de totalidade, em que a minúcia da observação opera como meio de se alcançar a ideia do todo. A ideia é um tanto obsessiva, quando aplicada à literatura, uma vez que sugere ao escritor o esquadrinhamento da realidade como única via em direção à “verdade" narrativa. Não é outro o teor do que Correia parece apontar como lacuna em Lúcio de Mendonça.

Outro contemporâneo que escreveu sobre os contos de Lúcio de Mendonça foi Filinto de Almeida (1857-1945), teatrólogo, poeta e escritor, marido da também escritora Júlia Lopes de Almeida, e colaborador em vários periódicos do Rio e de São Paulo. Será no Diário do Comércio, do Rio de Janeiro, que Filinto escreverá, em sua coluna intitulada "História dos sete dias", uma nota sobre a publicação de Esboços e perfis, que recebera há pouco tempo. A nota é uma pequena apresentação do livro para o público, em que Filinto expõe algumas qualidades do autor Lúcio de Mendonça, aborda a qualidade dos contos ali reunidos, nomeando alguns, cita um trecho retirado de um deles como demonstrativo do belo estilo do autor e por fim recomenda a leitura a seu público, que, se não vier a gostar do livro, certamente é por estar acostumado a leituras não tão agradáveis, estando com o "paladar inteiramente estragado pela prosa massuda e insípida do..." ${ }^{\text {, }}$, a quem não nomeia. Sobre o livro de Lúcio, em especial, diz o seguinte:

Neste seu livro de contos ligeiros, de variadas feições, estão as suas principais qualidades de artista caprichoso e de escritor imaginoso e fecundo. Propriedade de frase, originalidade no dizer, maneira peculiar e simples de narrar, e um fundo de observação larga, reduzida às conveniências do conto moderno, singelo episódio surpreendido de passagem num momento da vida social. ${ }^{198}$

O trecho é curto, mas nos parece que Filinto de Almeida foi ao cerne do que vem a ser a propriedade dos contos de Lúcio de Mendonça. Quanto ao estilo, reafirma o que Raimundo Correia já afirmara sobre o uso de palavras e frases, escritas com "propriedade". Aqui, no entanto, acrescenta dois pontos importantes para entendermos a técnica de Lúcio. Primeiro a "maneira peculiar e simples de narrar”, que nos parece referir ao modo direto que Lúcio tem de apresentar suas histórias, sem inversões temporais complexas, com narradores bastante objetivos, na sua imensa maioria em terceira pessoa,

\footnotetext{
196 AUERBACH, Erich. "Germinie Lacerteux”. In.: Mimesis: a representação da realidade na literatura

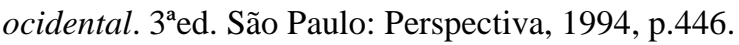

${ }^{197}$ Diário do Comércio, 13/05/1889.

198 Idem.
} 
sem as bisbilhotices de um onisciente intruso. Temos geralmente a impressão de que ali há um contador de histórias e causos, que à roda de uma fogueira diverte os ouvintes. Repare que essa simplicidade difere muito da maioria dos escritores de então, ou minuciosamente naturalistas, ou anacronicamente românticos. Apesar da elegância, os entorses irônicos de Machado de Assis também não se aproximam disso. Lúcio escreve com a simplicidade e naturalidade de quem fala, mas com a correção de quem conhece a língua que utiliza.

O segundo aspecto nos remete "ao fundo de observação larga, reduzida às conveniências do conto moderno, singelo episódio surpreendido de passagem num momento da vida social". Entendemos que o "fundo de observação larga" ao qual Filinto se refere significa a qualidade de Lúcio em atingir o aspecto essencial de uma história, seu cerne, com o larga significando, em sentido abrangente, profunda. Quanto ao qualificativo dado a essa observação, "reduzida às conveniências do conto moderno", é que talvez nos caiba discutir um pouco mais. Estamos aqui falando de síntese, é claro, mas também se coloca que a questão da capacidade de síntese do conto não tem a ver diretamente com sua extensão, mas com a profundidade dessa síntese em recolher o que há de essencial em uma história. Os contos românticos analisados no primeiro capítulo, todos curtos, não atingiam esse propósito, apesar do tamanho. Repare que, novamente, estamos aqui discutindo que o tamanho não é o que vai definir a qualidade do conto, mas o modo como cada autor lida com essa extensão. Termos lido inicialmente contos curtos demonstra essa afirmação e, por conseguinte, sugere que os escritores românticos, pelo menos os que tentaram a forma curta, não souberam como lidar com ela. Em 1889, ao menos, pelo que sugerem as palavras de Filinto de Almeida, já se sabia o que significava escrever contos modernos, ou seja, aqueles que recortavam um pedaço da realidade para demonstrar uma verdade da vida, "singelo episódio surpreendido de passagem num momento da vida social".

E como Lúcio faz isso? Os contos de Esboços e perfis têm, basicamente, três lugares como cenário: a São Paulo dos estudantes, parte da adolescência de Lúcio; o interior mineiro, paulista e fluminense, que compôs sua infância e seu início de carreira profissional; e a corte carioca, onde se estabelecera permanentemente em 1888. Essa disposição, aparentemente apenas geográfica, dará aos contos feições peculiares, dependendo de seus cenários. Evidentemente afirma-se isso em relação a um esquema geral do livro, havendo contos que não seguem necessariamente a mesma linha de 
composição. O que vale aqui dizer é que há um espírito presente em determinados contos que se lhes configuram como uma espécie de retrato local, talvez essa uma característica, contraditoriamente não regionalista, de Lúcio de Mendonça, porque não significa dizer que o autor retrate a paisagem do lugar, tão comum nos regionalistas. Para Alexandre Eulálio, por exemplo, Lúcio queria definir o homem dentro do grupo social ao qual se manifestava, não por ser, no caso do homem do interior, gaúcho, cearense ou paulista, como José de Alencar procurou fazer, mas por ter um "plano moral" específico e não desbastado pelo filtro do regionalismo. Em um trecho, diz Eulálio:

Eminentemente dramática, ao narrador interessando mesmo pelo seu drama, essa personagem existe de modo concreto para o autor, retratada num momento de crise. Momento decisivo, que pretende definir (ao mesmo tempo que o comportamento do seu grupo) o modo de ser profundo deste pequeno herói. ${ }^{199}$

Evidente que não se diz aqui que o sertanejo de Lúcio é um ser original e único, indivíduo pleno que só Guimarães Rosa irá conseguir. Mas se afirma que a intenção de Lúcio não é retratar uma região e seu pitoresco, mas de que interioridade esse homem procura enfrentar suas crises. Daí percebermos, quando o autor conta histórias do seu tempo de estudante, por exemplo, que ali pretende mostrar um modo de ser dentro de uma práxis social, adolescente, é verdade, mas banhada em autenticidade. É do que trata Eulálio, considerando que os melhores momentos de Lúcio são aqueles em que ele aprofunda a visão do drama do homem do campo, ressaltando a "discreta dignidade do caboclo" 200 .

O conto que abre Esboços e perfis é "O pedido de Isaura", breve história ambientada no Rio de Janeiro, ao sabor das estrepolias provavelmente típicas de jovens burgueses cariocas. O conto é ligeiro, adjetivo já usado pela crítica para classificar os contos de Lúcio de Mendonça, especialmente porque conta uma história cotidiana e banal, de um certo ar romântico, que será muito usado nos contos ambientados no Rio de Janeiro, e que de certa forma o aproxima bem dos textos de Artur Azevedo, esse contemporâneo de Lúcio tão conhecido por seus contos humorísticos, também assíduo frequentador das colunas literárias nos jornais da época. Embora ligeiro, a veia humorística de Lúcio de Mendonça não é a mesma de Artur Azevedo, que desde a adolescência escrevia comédias para o teatro ${ }^{201}$. Em Lúcio, o humor às vezes é contido por uma necessidade de expressão

\footnotetext{
${ }^{199}$ EULÁLIO, op. cit., p.62.

${ }^{200}$ Idem, p.62.

${ }^{201}$ Amor por anexins, por exemplo, foi publicada em 1872, quando o autor tinha apenas 17 anos.
} 
de uma interioridade latente, pouco consciente, mas que dá às histórias um leve toque de profundidade, no mesmo aspecto de drama moral que os contos mais sérios terão. Em "O pedido de Isaura", o humor tangencia os fatos e personagens, que se nos apresentam simpáticos e brejeiros, adjetivo este tão ao gosto do século XIX, prenunciando ao leitor um desfecho que provoque o riso. Embora a estrutura deste conto, datado de 1875, seja montada para o desfecho surpreendente e cômico, Lúcio dará um outro tom, romântico sem dúvida, mas que evita a futilidade de uma breve brincadeira de rapazes, buscando, talvez ainda imaturamente, um estofo moral para sua personagem. A aposta feita para a conquista do amor da costureira Isaura tem a sua meta invertida quando o apostador, o jovem e milionário Luís, apaixona-se pela moça. O que viria a ser mais uma conquista para o rol de desencaminhadas pelo rapaz, acaba por conquistá-lo, porque lhe apresenta uma dignidade não esperada, nem por ele, nem por seus amigos pelintras. A base é romântica, uma vez que o idealismo opera na constituição inabalável do caráter de Isaura, que se apaixonara por Luís, mas havia sido enganada ao achar que o rapaz era pobre. Quando se lhe revela a verdade, ela o rejeita, afirmando que "um milionário não se casa com uma costureira"202. O gesto - calculadamente desinteressado? -, dá ao rapaz rico a certeza da sinceridade nos sentimentos da moça. Nada mais romântico. Mas Lúcio sabe disso, e brinca com a questão, satirizando o anacronismo de um desfecho de puro teor romântico, em que a pureza dos sentimentos vence a astúcia dos interesses:

- Primeira declaração: Isaura ama-me.

- Por outra: diz que te ama. Sabe que és milionário, e eis só o que esperava aquela prolongada virtude.

- Enganas-te: julga-me pobre, e ama-me.

- Estou te desconhecendo, ó perito em mulheres! pois isso é coisa em que se creia assim! um amor em fins do século XIX! e desinteressado!... tem graça. ${ }^{203}$

Pode-se afirmar que Lúcio vive de uma contradição, já apontada por Alexandre Eulálio ao contrapor o substrato romântico do conto "Luiz da Serra", que é de 1897, aos demais contos rústicos de Lúcio, ou seja, na transição em que se situa, esgotamento dos preceitos românticos e advento de uma visão naturalista e realista da arte, Lúcio de Mendonça busca o retrato de uma sociedade despida de seu espalhafatoso aparato romântico, que sua contenção na escrita tão bem realiza, sem, no entanto, deixar-se levar pelo inescapável e determinista julgamento do naturalismo. Esses dois aspectos, em

\footnotetext{
${ }^{202}$ MENDONÇA, op. cit., p.15.

203 Op. cit., p.15.
} 
conjunto, são os que podem fornecer a Lúcio os elementos de sua busca em relação à forma do conto. De um lado, despir-se do aparato sentimental e derramado dos românticos, enxugando a forma de todo artificialismo sentimental. De outro, evitar o detalhamento naturalista, tornando sua prosa objetiva, mas sintética e direta, sem o cientificismo de vitrine dos naturalistas. "O pedido de Isaura”, embora ainda se ressinta de uma visão de mundo romântica, já enfrenta o problema da forma com certa desenvoltura, em se tratando de um conto ainda do início da carreira de Lúcio. Cenas rápidas, diálogos objetivos, síntese no tempo da história, efeito de surpresa, são alguns dos predicados do conto, ligeiro, em duas acepções.

Mesmo quando trata de temas trágicos, como é o caso de "Mãe cabocla", Lúcio de Mendonça procura sempre a pincelada rápida, precisa, que mostra o objeto, mas que por outro lado deixa espaço para a imaginação. Talvez por isso alguns de seus contos tenham uma qualidade que certamente faltou à maioria dos românticos e que os naturalistas também pouco souberam explorar, que é a síntese como elemento de composição do conto, no sentido de que através dela se estabelece uma abertura interpretativa ao leitor, esse um aspecto importante do conto moderno. Machado de Assis foi mestre nisso, mas também nas sugestões que sua ironia abria à leitura. Pompeia também, em seus melhores contos, com sua ironia trágica, também abre essas possibilidades. Lúcio procura fazer com que os próprios fatos, contados da maneira apropriada, sem intromissões desnecessárias de um narrador intruso, organizando o material narrativo de modo que os aspectos essenciais sejam enfatizados, que os fatos mostrem a poesia da história. Isso o faz avesso aos românticos, corpo estranho aos naturalistas.

"Mãe cabocla", nesse sentido, é um conto exemplar dentro da obra de Lúcio de Mendonça. Aqui, os fatos, por si repletos de ressonâncias, que vão do exercício abusivo do poder por parte das elites econômicas, políticas e religiosas, ao uso da violência como único modo de justiça em um meio de comandos corrompidos, até um misticismo de caráter popular, pouco lúcido, mas sempre sugestivo ao imaginário, os fatos se unem em uma cadeia de causas e efeitos friamente dispostos por um narrador que parece reproduzir apenas o que lhe disseram, como um bom contador de histórias. No entanto, a sua suposta objetividade narrativa é disfarce para a revelação crua da trágica condição por que passam os injustiçados. Frente à desfaçatez e à crueldade de uns, demonstradas com poucos recursos pelo narrador, não sem ressaltá-las, a violenta justiça dos que só têm na faca a 
possibilidade da redenção. Dividido em quatro partes, Lúcio prioriza os detalhes para a primeira, em que a situação é apresentada in media res. A mãe velha de Joaninha, moça pobre da povoação, vem clamar frente à casa do comendador João Câncio justiça pelo estupro que este senhor praticou contra sua filha. O alvoroço chama atenção do povo e do vigário, que jogava gamão com o farmacêutico e se aborrece do jogo interrompido. Percebendo o inconveniente do que a velha dizia de seu compadre João Câncio, o vigário manda seu guarda-costas enxotar a velha do lugar. Tudo o que interessa de informação ao leitor é apresentado em pequenos traços nessa primeira parte. $\mathrm{O}$ comendador era padrinho de batismo de Joaninha, mas achou por bem, agora que estava moça e iria se casar, desvirginá-la à força. A mãe desesperada pede justiça, que ninguém da comunidade, nem menos o padre, pretende lhe dar. O comendador é mais importante para o povoado do que a velha e sua filha. Ao contrário da justiça que rogava, a velha recebe a arbitrariedade do silêncio forçado estabelecido por quem tem o poder, afinal estamos, na inóspita localidade do conto, sob o mando dos homens e não da lei. Tudo está dado. Ao fim dessa primeira parte resta engolir a seco o desmando de que se é testemunha. As três partes seguintes, juntas, são menores que a primeira. Ao vaticínio da velha cabocla ainda na primeira parte, “A justiça do céu há de me escutar algum dia!...”, o narrador derrama como um raio, a partir da segunda parte, as consequências funestas de suas palavras, numa torrente avassaladora de acontecimentos. Na segunda parte, Joaninha morre. Não se sabe como, mas se desconfia que a mando do comendador, não provado, mas provável, já que certamente seria o habitual, face à posição social do comendador, chefe político, econômico e judicial da região. Daí a história de Joaninha terminaria, deixando ao vazio as palavras premonitórias de sua mãe. Para a terceira parte, o narrador dá um salto temporal, apontado de forma imprecisa, mas suficiente, porque retoma a primeira situação como se a passagem do tempo nada modificara no lugar e nos homens. O mesmo lugar, as mesmas pessoas, mas um elemento novo.

Era outra vez um fim de ano, no mesmo largo da matriz do arraial paulista. $\mathrm{O}$ sol canicular, que ali dardeja nos intervalos das grandes chuvas, queimava as calçadas da rua.

Passava pouco do meio-dia. À porta do sobrado do comendador João Câncio reuniam-se grupos consternados, e lá de dentro e de cima ouviam-se gemidos de choro.

Em frente da matriz, ao pé do cruzeiro, secava ainda ao sol uma poça de sangue; ali fora que minutos antes, um rapazinho do lugar, o Zé Miguel, bom 
aprendiz de seleiro, matara o comendador João Câncio com duas facadas no peito. ${ }^{204}$

O conto talvez pudesse terminar aqui, mas não é esse o efeito ainda a que Lúcio quer chegar. Como dissemos anteriormente, há um plano moral ${ }^{205}$ a ser visto. $\mathrm{O}$ conto quer caminhar para isso, porque é uma obra artística e não uma notícia policial. Que o vaticínio da velha já estivesse aqui cumprido, é fato, mas o efeito não visa o misticismo popular. Lúcio quer mostrar ainda algo mais. Contadas rapidamente as razões de Zé Miguel para o assassinato, nada que surpreenda, pois o comendador continuava sendo o mesmo facínora de sempre, a quarta parte narra o enterro do distinto concidadão do povoado. Aqui o narrador se permite um pouco de ironia, fato nem sempre comum em Lúcio de Mendonça, reparando que o irônico vem mais da disposição dos elementos do que do julgamento desse mesmo narrador, pondo a nu todo o mecanismo de poder e desmando imbricado no tecido social do povoado, conivente com toda a corrupção presente, ou por medo, ou por conveniência:

Houve acompanhamento de música, e junto à cova o vigário, com trêmulos dramáticos na voz, celebrou as virtudes daquele seu bem amado paroquiano, pai da pobreza... amigo do seu amigo... e a quem X. devia... a fortuna de possuir uma igreja... com duas torres tão...tão...

Como o qualificativo estava rebelde e o sol quente:

- Magníficas - assoprou o sacristão.

- ... bem acabadas! - concluiu o orador sagrado, achando enfim. ${ }^{206}$

Muito sinteticamente, nesse final, o narrador comenta o curioso caso de um lenço vermelho embebido em sangue, notado por alguns dos presentes, que havia sido enrolado aos braços da cruz de uma sepultura qualquer. O acaso prepara o efeito, em sua conclusão elíptica e sugestiva, e devolve o leitor à angústia desesperada e à esperança de justiça clamadas pela mãe de Joaninha, retomando o equilíbrio perdido no início. Embora a cena invoque, pela sugestão, o misticismo popular que, de certa forma, tangencia os contos de

\footnotetext{
${ }^{204}$ MENDONÇA, op. cit., p.36.

${ }^{205} \mathrm{Um}$ aspecto a ser ainda explorado em relação aos contos de Lúcio de Mendonça está ligado a esse plano moral. Andrés Jolles, em Formas simples, faz uma distinção entre o conto maravilhoso e o conto literário, localizando no primeiro a presença de uma moral ingênua, ou de uma ética afetiva, em que o sentimento de justiça e equilíbrio atuam a partir do elemento maravilhoso, que, nesse sentido, cumpre uma função. No conto maravilhoso, a ética residiria na ideia do que deveria ser, por isso é chamada de ingênua. Em "Mãe cabocla", de certa forma, com exceção feita ao aspecto do maravilhoso, uma ética semelhante opera, uma vez que a justiça do que deveria ser acontece por meios não necessariamente maravilhosos, mas certamente operados pela função de equilíbrio. Que o comendador continuasse a praticar seus desejos eróticos, não havia dúvida. Mas que a reação viesse pelas mãos do oprimido, num outro momento, está dentro do plano moral de que nos fala Alexandre Eulálio. O conto acaba com o que deveria ser. Ver JOLLES, Andrés. Formas simples. Trad. Álvaro Cabral. São Paulo: Cultrix, 1976.

${ }^{206}$ Idem, p.37.
} 
Lúcio, o que se tem aqui é um concreto retrato moral da motivação que carrega o conto para o teor trágico que possui.

Ninguém compreendeu desde logo, mas, com o contar e recontar, chegou o caso aos ouvidos da Sinhá Ana dos gatos, e esta pôde explicar que, na véspera, dia em que ela não arredara de ao pé da empanada, pouco depois da desgraça, tinha visto uma cabocla velha, alta, muito magra, agachar-se no largo, junto à poça do sangue do comendador, e molhar nele um lenço, o qual depois tornara a meter no seio. Era, provavelmente, o mesmo lenço.

Provavelmente. ${ }^{207}$

Por fim, se por um lado se pode dizer que Lúcio de Mendonça tem uma obra "bastante desigual"208, nas palavras de Alexandre Eulálio, por outro se pode afirmar também que seus contos atingem uma forma eficiente e artística, cônscio o autor das características próprias desse gênero, que praticou relativamente pouco, mas que soube manusear com habilidade. Assim como Machado de Assis e Raul Pompeia, podemos dizer que a qualidade dos contos de Lúcio de Mendonça deve tributo a uma certa independência de escolas literárias, em especial a romântica, já saturada em seu tempo, e a naturalista, que disfarçada num novo regionalismo, fazia o gosto da maior parte dos escritores de então. No fundo, talvez, ao ter como meta o homem em seu aspecto moral, o enquadramento das escolas the tolhesse aquilo que possivelmente tão bem conhecia: o caráter do ser humano.

\footnotetext{
${ }^{207}$ Idem.

${ }^{208}$ EULÁLIO, op. cit., p.63.
} 


\section{A APARÊNCIA DA FORMA E A ESSÊNCIA DO CONTO}

Histórias sem data (1884) é o quarto livro de contos de Machado de Assis. Publicado dois anos após Papéis avulsos, considerado por muitos, como já vimos, o marco zero do conto de qualidade no Brasil, não tem a mesma fama de seu predecessor, mas não há dúvida de que vemos neste livro toda a arte do gênero consolidada pelas mãos de um mestre. Nele estão histórias que preenchem as tantas antologias já feitas das obras de Machado de Assis: "A igreja do diabo", "Cantiga de esponsais", "Singular ocorrência", "Conto alexandrino", "Noite de almirante", "As academias de Sião" e outros mais, todos no primor da forma e da escrita precisa e reveladora do bruxo do Cosme Velho. Apontar todas as qualidades que essas histórias trazem seria como elaborar um manual de como escrever bons contos. Tudo avulta, tudo funciona, tudo é eficaz. Aqui a forma do conto está plenamente conquistada, no que tem de síntese, no que tem de modos de contar uma história, seja criando um perfil, como em "Uma senhora", seja visando um acontecimento extraordinário, como em "As academias de Sião", seja criando alegorias, como em "A igreja do diabo". Aqui a forma atinge a plenitude do gênero e consolida a opinião que se tem de Machado como contista que se iguala aos grandes narradores universais, como Tchekhov, Maupassant e Poe, se ficarmos apenas no século XIX. Mas vamos tentar observar pelo menos um desses contos, que possa nos servir para reflexões sobre o gênero em si e sobre o nível a que os contistas chegavam naquele momento no país.

Lembremos de "Galeria póstuma", publicado inicialmente em 2 de agosto de 1883, na Gazeta de Notícias. Nesse conto Machado pratica uma de suas predileções, que é o retrato psicológico de uma personagem. Em junho de 1879, nos diz o conto, morre o sexagenário Joaquim Fidélis, viúvo rico e pacato, homem de bom trato e querido por todo seu círculo social, ex-deputado, enfim, um homem de bem. Morre mansamente, em sua própria cama, após ter participado, naquela noite, de um baile, onde dançara com a viúva de um amigo. Como era forte e tinha boa saúde, a notícia certamente surpreendeu os que o conheciam, especialmente seu sobrinho, Benjamin, seu único parente, a quem acolhera e educara desde que o menino, agora um advogado formado, se tornara órfão. A primeira parte do conto trata dessa consternação social em torno da morte de Joaquim Fidélis, o impacto para os amigos mais próximos, a repercussão na Corte e o enterro, ao qual 
acorreram "muitas pessoas gradas" 209 . Nessa parte, vê-se o retrato de uma pessoa a partir do ponto de vista daqueles que com ela conviveram em sociedade: sua posição social, sua vida familiar, suas ocupações. É o retrato de um capitalista do Império, homem de relativa proeminência social, bom partido para senhoras solteiras e viúvas, embora jamais tivesse contraído segundas núpcias, por motivos não explicados. O que importa, e a primeira parta do conto faz isso, é mostrar que Joaquim Fidélis era um homem respeitado da sociedade carioca e sua morte causou grande pena aos que o conheciam. O distinto Joaquim, o que era de conhecimento de todos, era admirado. Se o conto ali terminasse, certamente ele seria um dos perfis laudatórios que os jornais da época muitas vezes publicavam, em que todas as virtudes sociais do morto eram louvadas perante o público, exaltando sua figura exemplar para o regozijo e conforto dos que choram sua perda. Essa primeira parte satisfaz uma premissa. Constrói-se a imagem de Joaquim Fidélis a partir do ponto de vista de uma classe social, a burguesia carioca, recheando-a de todo aparato necessário para sua confiabilidade enquanto referente. É um dos aspectos da verossimilhança, certamente o mais usado pela prática realista, como nos mostram alguns $\operatorname{críticos}^{210}$. Esse aspecto, com função determinada, está muito mais preso ao referente, uma vez que se vale dele para construir sua verossimilhança ${ }^{211}$, nos permitindo a crença na confiabilidade e respeitabilidade de Fidélis, fundamental para o efeito de contraste do conto, de raiz satírica. Tudo faz parte da necessidade do gênero, o retrato, ou perfil. Mas já vimos, no capítulo sobre Papéis avulsos, como Machado lida com os gêneros textuais, manipulando-os conforme seus objetivos. Aqui não será diferente.

\footnotetext{
209 ASSIS, Machado de. Histórias sem data. Edição preparada por Marta de Senna. São Paulo: Martins Fontes, 2005, p.71.

${ }^{210}$ Auerbach, em Mimesis, já vimos, faz longo estudo sobre o tema. Mas poderia citar ainda Franco Moretti, que analisa a função sociológica do procedimento, principalmente no capítulo "O século sério", presente no livro $O$ burguês: entre a história e a literatura; também Jacques Rancière, com uma abordagem de outro viés em relação a Moretti, e até mesmo a Barthes, no seu famoso estudo "O efeito de real", pois identifica um aspecto negligenciado por boa parte dos estruturalistas, que envolveria um elemento de ruptura de convenções anteriores do romance. Diz Rancière: "Vamos tentar demonstrar aqui que a inflação da descrição em detrimento da ação que faz a singularidade do romance realista não é a exibição das riquezas de um mundo burguês preocupado em afirmar a sua perenidade. Ela não é, tampouco, esse triunfo da lógica representativa que se descreve de bom grado. Ela marca, pelo contrário, a ruptura da ordem representativa e do que era seu cerne, a hierarquia da ação". De Rancière, ver O fio perdido: ensaios sobre a ficção moderna. Trad. Marcelo Mori. São Paulo: Martins Fontes, 2017, p.19. De Moretti, O burguês: entre a história e a literatura. Trad. Alexandre Morales. São Paulo: Três Estrelas, 2014. De Auerbach, em especial o capítulo "Germinie Lacerteux", de Mimesis, já citado.

211 Todorov: "São estes os dois níveis essenciais do verossímil: o verossímil como lei discursiva, absoluta e inevitável; e o verossímil como máscara, como sistema de procedimentos retóricos, que tende a apresentar essas leis como submissões ao referente". Claro que o conto de Machado se liga ao segundo aspecto descrito por Todorov, o de se submeter ao referente. No entanto, em Machado, essa submissão é calculada. Ver TODOROV, Tzvetan. "Introdução ao verossímil". In.: Poética da prosa. Trad. Cláudia Berliner. São Paulo: Martins Fontes, 2003, p.118.
} 
A segunda parte do conto narra a visita dos amigos de Fidélis ao sobrinho Benjamin, após a missa de sétimo dia. Todos almoçam com o rapaz, herdeiro único do tio, e recordam o morto, cada um contando uma anedota qualquer que os fizesse sorrir à lembrança das virtudes daquele que se fora. Ao final, solicitam ao sobrinho uma recordação física, um objeto qualquer, que pudessem guardar como resquício concreto da amizade que os ligava ao Fidélis. Benjamin abre o gabinete de trabalho do tio, fechado até então, e os amigos, cinco, escolhem algum objeto como recordação do finado. $\mathrm{O}$ sobrinho, que resolve pela primeira vez olhar ali o que era guardado, encontra, entre outros papéis, um caderno onde o tio, ao que lhe pareceu, escrevia um diário. Despertada a curiosidade de todos para o que Fidélis pudesse ter deixado registrado, passa-se então à leitura do diário.

Percebamos que a situação narrativa não é original: um manuscrito deixado por um morto que contém a verdadeira história a ser contada, já que a primeira lhe serve apenas de moldura e introdução. Vimos que as histórias românticas utilizavam o procedimento com frequência, como, por exemplo, Machado fez em "Frei Simão". Também vimos que o procedimento, nas histórias românticas, estava ligado a uma necessidade de estabelecer um estatuto de verdade ao que se contava, ou pelo menos que, se houvesse alguma dúvida quanto à verossimilhança do contado, essa dúvida não recaísse sobre o narrador "real", o que permanecia na história que preenchia a moldura. Em "Frei Simão", o manuscrito encontrado na cela beneditina do frei é que dá o teor melodramático da história do religioso. O narrador "de fora" apenas seleciona o que acha melhor, mas o conteúdo não é seu. Machado usa outro manuscrito beneditino em "A igreja do diabo", do mesmo Histórias sem data em que está "Galeria póstuma”. No entanto, se, em "Frei Simão", o distanciamento narrativo funciona como chancela de verossimilhança, no sentido de que a história melodramática do amor frustrado do frei adquire valor de verdade porque está sendo lida por outro, este pertencente ao mundo "real", em "A igreja do diabo", a leitura do manuscrito beneditino não cumpre a mesma função, pois o que se lê não tem a pretensão de estabelecer um estatuto de verdade da mesma forma que o manuscrito do frei teria, cumprindo aqui uma função do verossímil mais próxima do primeiro aspecto descrito por Todorov, o de "lei discursiva, absoluta e inevitável" 212 , no sentido de que se basta internamente sem a necessidade protocolar do referente. O narrador externo de "Frei Simão" poderia nos dizer: acredite no que estou

\footnotetext{
212 Ver nota 211.
} 
lendo, pois é verdadeiro, embora melodramático. Já o narrador de "A igreja do diabo" diria: não é necessário que seja verdade o que estou lendo, mas a história é boa. O primeiro narrador, romântico, precisa do estatuto da verdade para atestar a verossimilhança. $O$ segundo, não romântico, pouco se importa com a verdade: a verossimilhança se molda pela própria história. Na primeira, é verossímil, porque pode ser verdadeiro; na segunda, é verossímil, independente da verdade. Logo, a ideia de outro texto dentro do texto, gênero dentro do gênero, já praticada antes pelos românticos e, também, por Machado, agora tem função diversa. A princípio, o procedimento cria, entre leitor e história, um distanciamento. Na história romântica, esse distanciamento tem função empática, no sentido de dar ao leitor uma sensação de verdade sobre o contado, contraditoriamente aproximando-o da história narrada através do sentimento de se reconhecer na personagem, como nos mostrou Karin Volobuef ${ }^{213}$. No conto formalmente maduro de Machado de Assis e de outros, o distanciamento provocado por um narrador externo tem a função de estabelecer uma perspectiva crítica em relação ao narrado, ou, melhor dizendo, uma consciência diferenciada, como leitor, daquilo que as personagens vivenciam dentro da história. A ideia romântica é que o leitor sinta o que a personagem sente, que o ponto de vista dos dois entre em consonância, enquanto no conto posterior ${ }^{214}$ o que personagem e leitor sentem e veem são diferentes, às vezes de uma diferença amarga.

Aqui voltamos ao tema da forma. O conto romântico, segundo os críticos, possuía um problema de base que era a questão da extensão. Não apenas porque fossem longos, mas porque em geral se pareciam com novelas ou romances não desenvolvidos, mal acabados. Observando contos de extensão menor, entendemos que o problema não reside na extensão do conto em relação ao número de páginas que possui. Contos curtos se mostraram, paradoxalmente, extremamente longos. A disposição temporal no conto de Paula Brito, as ações dinâmicas em excesso no conto de Álvares de Azevedo, o artificialismo da concepção romanesca contaminada pelo melodrama em "Frei Simão",

\footnotetext{
213 Op. cit., 1999.

${ }^{214}$ Quando digo "conto posterior", não estou me referindo ao conto naturalista, uma vez que este, assim como o conto romântico, está bastante preso ao referente, de uma forma diferenciada do romântico, porque tem um preceito cientificista, mas preso. Machado trabalha a referência de um modo muito particular, pois em diversos contos se utiliza de argumentos absurdos que minimizam a noção exterior do referente, como se vê, entre tantos outros, em "Sereníssima República". Raul Pompeia, como bom caricaturista que era, distorce o referente ao máximo, retirando parte de seu peso, como vemos em "14 de julho na roça". Lúcio de Mendonça - dos três, o mais preso ao conceito de referente - pela concisão, desbasta sua interferência, equalizando sua função apenas em torno do objetivo a ser alcançado pela ação, como vemos na maior parte de seus contos.
} 
de Machado de Assis, mostraram que o problema maior residia não na extensão dos contos, mas na capacidade que possuíam de sintetizar todas as questões da forma, no sentido de atingirem seus objetivos. Concluímos, a partir das análises, que o conto romântico criava para si, em função das dificuldades acima citadas como falhas, uma imperiosa necessidade de verossimilhança, o que acarretava um ciclo vicioso na narrativa, que, se conseguia ser bem resolvida no romance alongando-se até que fosse satisfeita, para o conto se tornava altamente pernicioso, dada sua necessidade de síntese. O fato de os autores românticos "precisarem" dar um estatuto de verdade para o que escreviam $^{215}$, de certa maneira, lhes criava uma problemática em relação à forma, que no conto não encontrou solução. Um retrato psicológico profundo, como os que Machado passou a fazer, encontrava imensa dificuldade de ser elaborado pelos românticos. $\mathrm{O}$ artificialismo na construção da verossimilhança, com suas ações em cadeia, seus excessos de melodrama, seus prolongamentos temporais, obstruía a construção aprofundada da personagem, que nos parece, em geral, superficial. Faltou aos românticos o que viemos aqui chamando de concentração, a determinação em explorar um aspecto da história antes de passar adiante. No caso dos românticos, o problema apresentava seus principais sintomas na construção da intriga, que se enveredava indefinidamente, multiplicando as ações e impossibilitando a crença verossímil na transformação da personagem, que parecia apenas manipulada pelas peripécias. A ideia de Todorov de que "a intriga mínima completa consiste na passagem de um equilíbrio para outro" 216 dificilmente se resolve no conto romântico, que não parece compreender o significado do termo "mínimo". Indo um pouco além, pode-se dizer que a capacidade imaginativa mobilizada pelo romantismo, em conflito com o dever de construção de uma verdade ao leitor, intimamente aceita pelos nossos escritores românticos, criou um fosso estrutural para o conto nesse período: sua

\footnotetext{
${ }^{215}$ Pensemos, numa outra perspectiva, o que os escritores tiveram que tomar para si como necessidade quando lembramos a ideia de construção de nação jogada ao colo dos românticos. Ao mesmo tempo que deviam dar vazão a sua imaginação agora livre, deveriam também contribuir para a elaboração de uma visão de Pátria até então inexistente. Esse compromisso, portanto, precisava de bases concretas para que pudesse ser executado. Não à toa, o regionalismo romântico irá "percorrer" o país para dar uma visão pretensamente etnológica de nosso povo. Ao final do período, Franklin Távora acusará Alencar pela etnologia de gabinete. Mas a contradição estava posta, como bem aponta Antônio Candido na Formação da literatura brasileira: "Como se vê [comentando palavras de um crítico romântico, Macedo Soares], é um levantamento bem compreensivo, feito já no auge do Romantismo e tendo por mola o patriotismo, que se aponta ao escritor como estímulo e dever. Com efeito, a literatura foi considerada parcela dum esforço construtivo mais amplo, denotando o intuito de contribuir para a grandeza da nação. Manteve-se durante todo o Romantismo este senso de dever patriótico, que levava os escritores não apenas a cantar sua terra, mas a considerar as suas obras como contribuição ao progresso. Construir uma 'literatura nacional' é afã, quase divisa, proclamada nos documentos do tempo até se tornar enfadonha". In.: Formação da literatura

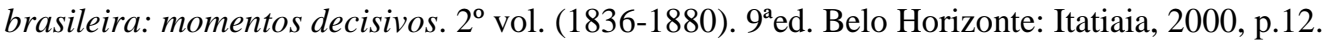

${ }^{216}$ Poética da prosa, p.153.
} 
qualidade deveria estar na síntese profunda de uma situação ou acontecimento, mas o excessivo aparato de construção do verossímil impede que isso aconteça. Não podemos ver a essência de uma personagem romântica no conto, porque ela está escondida atrás de uma densa vegetação retórica.

E por que o conto, após o romantismo, nos permite ver essa essência? O que foi feito para que o que estava oculto no conto romântico viesse à tona posteriormente? Voltemos a "Galeria póstuma".

Vimos que a primeira parte nos deu o retrato social de Joaquim Fidélis. Ali temos uma página de coluna social, tão ao gosto da burguesia endinheirada de nossas cidades. Não é necessário repetir os termos elogiosos elencados para o morto. A segunda parte nos colocou com os amigos e o sobrinho rememorando o falecido Fidélis, quando o diário que o tio escrevia é encontrado pelo rapaz. Passa-se à leitura do diário e então um outro Joaquim Fidélis passa a ser conhecido. Inicialmente apenas um escritor de talento:

O interesse do escrito adormeceu a dor do óbito. Era um livro digno do prelo. Muita observação política e social, muita reflexão filosófica, anedotas de homens públicos, do Feijó, do Vasconcelos, outras puramente galantes, nomes de senhoras, o da Leocádia, entre outros; um repertório de fatos e comentários. Cada um admirava o talento do finado, as graças do estilo, o interesse da matéria. Uns opinavam pela impressão tipográfica; Benjamin dizia que sim, com a condição de excluir alguma coisa, ou inconveniente ou demasiado particular. E continuavam a ler, saltando pedaços e páginas, até que bateu meio-dia. ${ }^{217}$

As qualidades de Fidélis, até aqui, lembram muito o retrato do medalhão, elaborado no conto "Teoria do medalhão", de Papéis avulsos. Temos um homem colocado em uma posição social de admiração e respeito por parte da sociedade, mas certamente inócuo para as bases que a sustentam. Fidélis cumpriu seu papel social, não criou constrangimentos, não abalou os pilares do Império. Pode agora morrer sob o aplauso e a lágrima, em paz com o dever e a sociedade. Era de fato o que todos os seus conhecidos imaginavam. No entanto, após a saída dos amigos para seus afazeres, não sem antes prometerem retornar no dia seguinte para a continuação da leitura, percebe-se que os escritos não guardavam apenas talento e confirmação da alma generosa e respeitável de Fidélis. Agora solitário, o sobrinho prossegue a leitura do diário. Repare como Machado lida com a situação narrativa: há uma informação a ser dada, que é o conteúdo do diário, mas no momento em que personagens e leitores estão prestes a se apropriarem

\footnotetext{
${ }^{217}$ Histórias sem data, p.72.
} 
dessa informação, a narrativa faz uma pausa. A pausa é providencial, pois permite agora que separemos uns e outros, aqueles que se tornarão cientes do conteúdo e os que ficarão ignorando-o. Cria-se um descompasso, percebido pelo leitor, que, privilegiadamente, estará entre os informados. O privilégio é uma posição cômoda, mas também pode ser crítica. É também instrumento de poder, uma vez que se tem o que o outro não dispõe, e por isso pode ser usado a seu favor. De qualquer modo é um algo a mais, que lhe coloca um patamar acima de outros, proporcionando uma visão diversa e ao mesmo tempo superior. É um modo de distanciamento, mas veremos que aqui o procedimento tem função crítica.

Ao ler sozinho o conteúdo do diário, o sobrinho tem uma surpresa. O que passa a ler, após a saída dos cinco amigos do tio, são perfis e retratos que Joaquim Fidélis produzia desde 1873 (lembremos que estávamos em “junho de 1879”). O gênero parece ser do apreço do tio, que "era exímio nos retratos".

Desde 1873 ou 1874, os cadernos vinham cheios deles, uns de vivos, outros de mortos, alguns de homens públicos, Paula Sousa, Aureliano, Olinda, etc. Eram curtos e substanciais, às vezes três ou quatro rasgos firmes, com tal fidelidade e perfeição, que a figura parecia fotografada. Benjamin ia lendo; de repente deu com o Diogo Vilares. ${ }^{218}$

A surpresa inicial ainda está relacionada com a capacidade ímpar do tio em ser extremamente fiel ao que retrata, como diz o trecho. No entanto, essa surpresa se tornará estupefação ao deparar com o que o tio escreve sobre Diogo Vilares, um dos cinco amigos presentes até então. É aqui que aquele distanciamento referido anteriormente vai expor seu mecanismo. Ocorre uma transformação, de ordem complexa, porque toda a imagem até então construída para a figura do tio desmorona, sob a leitura dos retratos, criando um abismo entre o que parecia antes e o que era agora. Essa transformação de aparência, na tipologia de Todorov ${ }^{219}$, é o fulcro do conto, e, pode-se dizer, a base criativa da maior parte dos contos após Papéis avulsos. É necessário que algo aparente, mas não que seja.

\footnotetext{
${ }^{218}$ Idem, p.73.

219 "Voltamo-nos agora para o segundo tipo de transformações, aquelas que produzem não uma especificação do predicado inicial mas a anexação de uma ação derivada à ação primeira. As transformações que chamo 'de aparência' indicam a substituição de um predicado por outro, sendo que este último pode se fazer passar pelo primeiro, sem na verdade sê-lo. Em francês, designa-se uma transformação desse tipo com os verbos feindre, faire semblant, pretendre, travestir [fingir, fazer de conta, dar-se ares de, disfarçar] etc.; como se vê, essas ações baseiam-se na distinção entre ser e parecer, ausente em certas culturas. Em todos esses casos, a ação do primeiro predicado não é realizada". TODOROV, Poética da prosa, p.308. Vemos que predicado do primeiro momento, a admiração e o respeito, não pode ser realizado após a leitura do diário. Mas, como é Machado, ele acrescenta outro mecanismo, mantendo ironicamente a realização do predicado inicial.
} 
Os cinco amigos íntimos de Joaquim Fidélis serão retratados em seu diário, todos lidos pelo sobrinho, que também será assunto de um retrato, e pelo leitor. O sobrinho passa a ter agora uma informação que nenhum outro personagem tem. E o leitor é seu cúmplice. E de que forma isso se relaciona com a forma do conto?

Lembremos do que Machado afirma em 1873, no artigo "Instinto de nacionalidade", quando se refere à escritura de contos no Brasil. Ele conclui, em um trecho, que "tem havido tentativas mais ou menos felizes, porém raras" 220 . A insatisfação com a qualidade do gênero aqui, dez anos antes de "Galeria póstuma", já era declarada. Vimos que o descontentamento com a forma romântica, até então predominante, de se escrever contos, levou escritores como Machado, Raul Pompeia e Lúcio de Mendonça a renovarem a fatura dessa produção, atacando-a nos pontos mais nevrálgicos e vulneráveis da escrita romântica. O primeiro passo, sem dúvida, se estabeleceu através da contenção da matéria narrativa. O conto deixou de parecer um romance esboçado, repleto de episódios e lugares, e passou a se concentrar em um único episódio, desmembrado, quando muito, em poucas cenas. A concentração da ação abriu o campo dos escritores para novas experimentações. "A chinela turca", por exemplo, vai aproveitar o espaço agora conquistado para parodiar satiricamente o próprio procedimento anterior. A concentração passa a ser a pedra fundamental do novo edifício narrativo do conto, e então o campo de ação em outros fundamentos passa a ser mais explorado e aprofundado, sempre tendo como meta arquitetônica a síntese. "Galeria póstuma" tem apenas duas partes. A primeira, como já vimos, apresenta Joaquim Fidélis antes da morte. A segunda, depois da morte. Na primeira se vê o homem sério e respeitado, admirado pelos amigos, amado pelo sobrinho, referido pelos jornais. A concentração do conto está em formar essa imagem na primeira parte, bem delineada, sem necessidade de torneios de enredo ou lances melodramáticos. Tudo pincelado como num retrato, que será o motivo principal da segunda parte. E o que essa segunda parte é, afinal? Assim como a morte na segunda é a antítese da vida da primeira, o homem sério e respeitado, digno e admirado da primeira, se tornará o ferino e mordaz observador da segunda. A pátina social de Joaquim Fidélis não tem mais função, pois só a tinha enquanto era vivo. Morto, sua personalidade se revela integralmente nos cadernos de seu diário, escondidos até então como matéria proibida à sociedade. O diário, aqui, exerce função semelhante ao "outro lado da vida", de onde Brás Cubas nos narra suas Memórias póstumas, romance decisivo na carreira de

\footnotetext{
${ }^{220}$ Novo Mundo, 24 de março de 1873.
} 
Machado de Assis, de 1881. No capítulo em que explica a ideia do emplasto, Brás diz que sua "ideia trazia duas faces, como as medalhas, uma virada para o público, outra para mim"221. Não é gratuita a comparação, pois o que se vê na segunda parte do conto é o desnudamento do que o ex-deputado Joaquim Fidélis pensava sobre a vida e sobre as pessoas, que jamais antes havia declarado, assim como para o defunto Brás Cubas não existe mais opinião alheia que lhe impeça de dizer o que pensa. A segunda parte de “Galeria póstuma", portanto, dará, de um outro lado, o da escrita secreta e confessional de Fidélis, o retrato implacável do círculo de amigos por onde o viúvo transitava. Dois movimentos no conto, concentração na fatura de uma oposição só desvelada por um único lance de enredo, a descoberta do diário. A estupefação do sobrinho é ter, diante de si, integralmente revelado, quem era verdadeiramente seu tio, até então apenas o homem que lhe educara e criara como a um pai. O que o sobrinho conhecia de seu tio era apenas a aparência, a face da medalha virada para o público, não sua essência, a face que escondia de todos os outros, porque tinha uma posição e reputação pelas quais devia zelar. No entanto, a essência, que só o próprio Fidélis conhecia, podia ele mostrar a seu diário, que certamente não lhe censurava as confissões impublicáveis, já que não pertencia ao olhar da opinião.

Dos amigos, vejamos o que Fidélis escreve sobre um deles, o Elias, no mais longo dos trechos citados pelo narrador, dentre os cinco perfis que o sobrinho lê, antes de ler o seu próprio, que o fará, atordoado com a sinceridade mordaz do tio, e receoso do que de si teria dito afinal o tio Joaquim:

Elias Xavier. - Este Elias é um espírito subalterno, destinado a servir alguém, e a servir com desvanecimento, como os cocheiros de casa elegante. Vulgarmente trata as minhas visitas íntimas com alguma arrogância e desdém: política de lacaio ambicioso. Desde as primeiras semanas, compreendi que ele queria fazer-se meu privado; e não menos compreendi que, no dia que realmente o fosse, punha os outros no meio da rua. Há ocasiões em que me chama a um vão da janela para falar-me secretamente do sol e da chuva. O fim claro é incutir nos outros a suspeita de que há entre nós coisas particulares, e alcança isso mesmo, porque todos lhe rasgam muitas cortesias. É inteligente, risonho e fino. Conversa muito bem. Não conheço compreensão mais rápida. Não é poltrão nem maldizente. Só fala mal de alguém, por interesse; faltandolhe interesse, cala-se; e a maledicência legítima é gratuita. Dedicado e insinuante. Não tem ideias, é verdade; mas há esta grande diferença entre ele e o Diogo Vilares: - o Diogo repete pronta e boçalmente as que ouve, ao passo que o Elias sabe fazê-las suas e plantá-las oportunamente na conversação. Um caso de 1865 caracteriza bem a astúcia deste homem. Tendo dado alguns

${ }^{221}$ ASSIS, Machado de. Memórias póstumas de Brás Cubas. São Paulo: Penguin Classics/Companhia das Letras, 2014, p.36. 
libertos para a guerra do Paraguai, ia receber uma comenda. Não precisava de mim; mas veio pedir a minha intercessão, duas ou três vezes, com um ar consternado e súplice. Falei ao ministro, que me disse: - 'O Elias já sabe que o decreto está lavrado; falta só a assinatura do Imperador.' Compreendi então que era um estratagema para poder confessar-me essa obrigação. Bom parceiro de voltarete; um pouco brigão, mas entendido. ${ }^{222}$

É difícil encontrar trecho desse gênero no conto romântico, não porque os escritores não fossem capazes de uma observação tão fina, mas talvez porque o retrato seja extremamente concentrado no que se percebe da essência de Elias, a partir de uma análise objetiva e sagaz de seu comportamento social. O retratista, Fidélis, não deixa escapar um lance que não lhe entregue algo da personalidade do amigo. Se o amigo o chama secretamente para dizer futilidades, percebe como os demais se aproximam de Elias para bajulá-lo, tendo em mente uma intimidade inexistente. Um único lance de comportamento é suficiente para a percepção do analista. O romântico teria criado inúmeras situações para chegar ao mesmo resultado, o que o desviaria do foco, que era dar somente a característica de forma direta, mas sutilmente irônica.

A eficácia do conto de Machado reside num aspecto bastante simples: a verossimilhança se constrói através da reiteração do mesmo aspecto em pequenas doses. Embora possa surpreender ao leitor do século XIX que uma personagem tão distinta como Joaquim Fidélis pudesse ter uma visão tão ácida da vida e dos homens, não causa dúvida a sinceridade de seus retratos, mesmo com o teor com que se apresentam, pois criam entre si uma cadeia uniforme de relações e intersecções, que passa longe de alguém supô-los apócrifos, não só porque tinham "a mesma letra do tio", mas também porque possuem uma fina coerência interna. Não é necessário saber se Joaquim Fidélis tivera algum desgosto com a humanidade que o tornara um cético em relação aos homens. Basta ler o diário e compreendê-lo, talvez pasmo, mas ainda assim coerente. O mecanismo exige pouco, no sentido de que se pode omitir detalhes anteriores da vida do tio, ou mesmo sua anterior vida de casado que lhe explicasse o celibato futuro, sem perder o efeito. Machado entendeu isso, assim como Pompeia e Lúcio de Mendonça, com outras características, também.

O conto de Machado pode ainda nos fornecer outra imagem para nossa análise. Após ler as palavras ferinas sobre os cinco amigos, estupefato, o sobrinho leu as que o tio

\footnotetext{
${ }^{222}$ Histórias sem data, p.75.
} 
lhe reservara. Poucas, é verdade, não tão ferinas quanto às outras, até mesmo um pouco condescendentes, mas nem por isso incômodas, pois ocasionam a interrupção da leitura.

Quis reler, e não pôde; essas poucas linhas davam-lhe a sensação de um espelho. Levantou-se, foi à janela, mirou a chácara e tornou dentro para contemplar outra vez as suas feições. Contemplou-as; eram poucas, falhas, mas não pareciam caluniosas. Se ali estivesse um público, é provável que a mortificação do rapaz fosse menor, porque a necessidade de dissipar a impressão moral dos outros dar-lhe-ia a força necessária para reagir contra o escrito, mas, a sós, consigo, teve de suportá-lo sem contraste. Então considerou se o tio não teria composto essas páginas nas horas de mau humor; comparou-as a outras em que a frase era menos áspera, mas não cogitou se ali a brandura vinha ou não de molde.

O sobrinho se distancia do escrito. Necessita refletir sobre ele, tentar entendê-lo e, em especial, tentar compreender sua gênese e motivação. Nós, leitores, o acompanhamos com o mesmo estupor. $\mathrm{O}$ incômodo do sobrinho é mais intenso que o nosso, uma vez que o que leu lhe provoca "a sensação de um espelho". Parece lhe ter sido revelado o que até então ignorava, ou não fazia questão de tê-lo consciente: sua própria essência. A do tio já vira e se espantara; a dele, que lhe aparentava fiel, lhe tiraria o sono aquela noite. Repare a funcionalidade do distanciamento aqui: a perspectiva alterada em relação ao escrito é problematizada pelo sobrinho a partir do ponto em que, como um espelho, vê a si mesmo. Já era problemática enquanto observava o tio que desconhecia. Quando vê a si, duplica a visão, o que a torna mais complicada. O distanciamento é crítico, em dois sentidos, primeiro porque leva a personagem a uma reflexão crítica, e nós, leitores, vamos de cambulhada, e segundo porque a coloca (a personagem do sobrinho) em uma situação crítica, na qual precisa se decidir que atitude tomar frente a um desnudamento tão violento e profundo da verdade. A personagem está numa encruzilhada. Em Lúcio de Mendonça isso se faz através de uma decisão moral, em que a ética da personagem atua de modo a escolher o único caminho certo, o da decisão interior, como vimos em "Mãe cabocla". Em Raul Pompeia se faz escancarando a indecência e hipocrisia social, como, por exemplo, em "Antes e depois", ou quando lança à cara da sociedade seus processos imorais de poder, como faria em "14 de julho na roça", lembrado após o episódio em que desafiou os fazendeiros escravistas de São Paulo. Machado, como procedimento mais típico, faz uso da ironia, ou da "eterna contradição humana", como conclui Deus em "A igreja do diabo"223, estabelecendo um pacto de hipocrisia entre personagem ou narrador e leitor, que assumem a imoralidade de uma

\footnotetext{
${ }^{223}$ Histórias sem data, p.17.
} 
decisão, desde que tudo fique como está. Em "Galeria póstuma” será exatamente a sensação que ficará, não sem um certo sorriso cúmplice, quando Benjamin decide não mostrar aos amigos do tio o restante do diário, nada dizendo, mas disfarçando o constrangimento da situação até que os amigos o percebessem e decidissem por ir embora, evidentemente falando mal do sobrinho: "Que diferença do tio! que abismo! a herança enfunou-o! deixá-lo! ah! Joaquim Fidélis! ah! Joaquim Fidélis!"224. Aqui é que Machado transpõe a transformação de aparência, pois, embora dê acesso ao leitor a essa mudança, não permite que a história a converta em um novo predicado, transformando, de fato, o antes em depois ${ }^{225}$. A essência é revelada, mas o que permanece e continua valendo é a aparência, que regia as personagens e continuará sendo senhora absoluta de seus destinos, como a ignorância dos amigos demonstra. Ao sobrinho, a quem coube a verdade, a aparência se impõe como moral social, função de controle das singularidades humanas, estabelecida pelo silêncio das contradições das personagens.

Os três contistas que chegaram a um amadurecimento da forma do conto Machado, Pompeia e Lúcio - possuem um forte foco numa proposta de desnudamento dos comportamentos sociais. Cada um a sua maneira, dando mais ênfase a um ou outro aspecto técnico, procuraram revelar que sob a aparência social de uma sociedade que se via como liberal e progressista, havia uma essência conservadora e cruel, desveladas em sua hipocrisia, interesses, violência, sede de poder e dinheiro. O salto que se dá em relação ao conto, já a partir dos anos de 1870, mas especialmente a partir da década de 80 do século XIX, tem relação direta com o aproveitamento crítico de elementos da técnica do conto já presentes em alguns dos românticos, mas até então mal equacionados. Machado, Pompeia e Lúcio compreenderam a função da síntese no gênero de modo que ela lhes propiciasse contundência e efeito em seus escritos. Dali perceberam o que significaria o uso da concentração em seus contos. Ao retirarem o que sobrava no conto romântico, puderam perceber que aquela fatura escamoteava a essência do que se pretendia atingir, como se os românticos ocultassem sob seu aparato narrativo a falta de profundidade de suas histórias e personagens. A aparência ocultando a essência. A verossimilhança, nesse sentido, tornou-se uma equação a ser solucionada, a fim de que não impedisse, em virtude de um pacto de realismo ${ }^{226}$, a intensidade dos objetivos e metas do conto. O

\footnotetext{
${ }^{224}$ Idem, p.80.

225 Ver nota 219.

226 Entenda-se a palavra "realismo" aqui como a necessidade de aproximação do leitor com sua vida cotidiana, de uma realidade que está fora do texto, no sentido semelhante ao que Barthes discute em "O
} 
distanciamento da perspectiva, assim, veste-se de uma roupagem crítica que os românticos não conseguiram usar, porque não a perceberam ou porque não conseguiram resolvê-la em função de todo o aparelho verossímil. Outro elemento importante para esse distanciamento crítico está no uso da ironia, pouco usada por Lúcio de Mendonça, usada de forma às vezes trágica por Pompeia, e largamente elaborada por Machado de Assis. A ironia acentua a distância, desnuda sem comprometer inteiramente, sem dar sua cara inteira para bater. Veja-se, por exemplo, a violência contundente da ironia satírica de Raul Pompeia em "14 de julho na roça" 227 , comparada com a ironia da desfaçatez e hipocrisia de Machado de Assis em "O caso da vara", conto de 1891, publicado na Gazeta de Notícias. Uma imagem de "Galeria póstuma” talvez ilustre isso melhor.

Quando Benjamin sai da janela para tentar encontrar uma resposta para suas angústias em relação ao que lera, revendo as páginas, tentando encontrar algo que desse uma pista para o conteúdo ferino dos escritos e finalmente nada conseguindo concluir, resolveu pensar no tio enquanto vivo e nos seus comportamentos diários, se dali pudesse tirar um indício do que o levara a ser tão ácido em seu diário.

Para confirmar a conjectura, recordou as maneiras usuais do finado, as horas de intimidade e riso, a sós com ele, ou de palestra com os demais familiares. Evocou a figura do tio, com o olhar espirituoso e meigo, e a pilhéria grave; em lugar dessa, tão cândida e simpática, a que lhe apareceu foi a do tio morto, estendido na cama, com os olhos abertos, o lábio arregaçado. Sacudiu-a do espírito, mas a imagem ficou. Não podendo rejeitá-la, Benjamin tentou mentalmente fechar-lhe os olhos e consertar-lhe a boca; mas tão depressa o fazia, como a pálpebra tornava a levantar-se, e a ironia arregaçava o beiço. Já não era o homem, era o autor do manuscrito. ${ }^{228}$

O que a ironia revela, e os contistas românticos no Brasil não conseguiram equacionar $^{229}$, é que o distanciamento proporcionado pela técnica irônica, no sentido de diferenciar o homem do autor do manuscrito, é também o mote para se questionar a relação estabelecida entre o leitor e o texto, fator primordial para a leitura crítica

efeito de real”, de 1968. Ver BARTHES, Roland. "O efeito de real”. In.: O rumor da língua. Tradução de Mário Laranjeira. São Paulo: Martins Fontes, 2004.

${ }^{227}$ Northrop Frye faz a seguinte afirmação sobre ironia e sátira, diferenciando-as: "A principal distinção entre a ironia e a sátira é que a sátira é uma ironia militante: suas normas morais são relativamente claras e ela pressupõe padrões contra os quais o grotesco e o absurdo são medidos" (p.369). E mais à frente: "Por isso, a sátira é a ironia que está estruturalmente próxima ao cômico: o embate cômico entre duas sociedades, uma normal e outra absurda, reflete-se no seu foco duplo de moralidade e fantasia" (p.370). FRYE, Northrop. Anatomia da crítica: quatro ensaios. Trad. de Marcos de Martini. São Paulo: É Realizações, 2013. Lembremos que Raul Pompeia, em "14 de julho na roça", descreverá o banquete dos fazendeiros ao melhor estilo do Pantagruel, de François Rabelais.

${ }^{228}$ Histórias sem data, p.79.

${ }^{229}$ Ver VOLOBUEF, p.261. 
assimilada pelos autores brasileiros a partir de então como procedimento de base. Chamar atenção para o próprio texto, a chamada metalinguagem, é usado como meio de atingir a essência da história, de aguda crítica, seja pelo distanciamento apenas, ou pelo distanciamento aliado à ironia. No caso de Machado, permeada de humor.

O fato de, na última cena de "Galeria póstuma", os amigos deixarem a casa de Joaquim Fidélis, agora propriedade de seu sobrinho, desdenhando o rapaz, mas completamente ignorantes da seiva venenosa que o finado amigo lhes havia reservado no diário, é um indício do descompasso proposto pelo conto, e aqui reafirmo, pelos objetivos a que os autores se mobilizaram naquele momento, entre duas realidades, duas faces $d a$ mesma medalha, aquela que é aparente e conhecida pelo ambiente social e a que se omite, face voltada para dentro, secreta e desconhecida, mas muito mais próxima de uma essência do que é o homem em sua realidade mundana. O jogo, principalmente em Machado, é deixar que essa essência seja entrevista, através de uma fenda ${ }^{230}$. Mas a tese não se restringe a isso, uma vez que tentamos demonstrar que a forma do conto só consegue atingir esse nível de revelação a partir do instante que os escritores contemporâneos a Machado se deram conta da falha estrutural no gênero, advinda do romantismo. O desnudamento das relações humanas e de classe, o desmascaramento da hipocrisia e dos desmandos da elite, o retrato aprofundado das personagens, no intuito de desvendar-lhes o mais íntimo, tudo isso através da escritura dos contos, só foi possível porque o gênero foi destituído daquilo que lhe poluía, que lhe tornava ineficaz para expressar o retrato de um momento, assumir o seu papel de registro fotográfico, dando ênfase ao estático, concentrando-se no essencial, como afirmaria a analogia de Julio Cortázar ${ }^{231}$. Os amigos que deixam sua casa falando mal da comida e do vinho não fazem a menor ideia não fazem a menor ideia do que o anfitrião pensa sobre eles. Só o conto pode nos revelar. Sem que os amigos saibam. Em poucas linhas.

\footnotetext{
${ }^{230}$ Alfredo Bosi afirma: “À medida que cresce em Machado a suspeita de que o engano é necessidade, de que a aparência funciona universalmente como essência, não só na vida pública mas no segredo da alma, a sua narração se vê impelida a assumir uma perspectiva mais distanciada e, ao mesmo tempo, mais problemática, mais amante do contraste. Rompe-se por dentro o ponto de vista ainda oscilante dos primeiros contos. A ambiguidade do eu-em-situação impõe-se como uma estrutura objetiva e insuperável". "A máscara e a fenda". BOSI, op. cit., p.84.

231 "Nesse sentido o romance e o conto se deixam comparar analogicamente com o cinema e a fotografia, na medida em que um filme é em princípio uma 'ordem aberta', romanesca, enquanto que uma fotografia bem realizada pressupõe uma justa limitação prévia, imposta em parte pelo reduzido campo que a câmera abrange e pela forma com que o fotógrafo utiliza esteticamente essa limitação". CORTÁZAR, Julio. “Alguns aspectos do conto". In.: Valise de cronópio. São Paulo: Perspectiva, 1993, p.151.
} 


\section{Bibliografia}

ABELARDO, Pedro. Correspondência de Abelardo e Heloísa. Apresentação de Paul Zumthor. Trad. Lúcia Santana Martins. São Paulo: Martins Fontes, 1989.

ABREU, Capistrano de. "Raul Pompéia". In: Ensaios e estudos. $1^{a}$ série. 2.ed. Rio de Janeiro: Civilização Brasileira; Brasília: INL/MEC, 1975, p.162-164.

ADORNO, Theodor. "Posição do narrador no romance contemporâneo". In: Notas de literatura I. Trad. Jorge Almeida. São Paulo: Duas Cidades; Ed. 34, 2003.

ARARIPE JÚNIOR. "Degenerescência da ficelle e queda do romantismo". In: COUTINHO, Afrânio. Obra crítica de Araripe Júnior, vol. II. Rio de Janeiro: Ministério da Educação e Cultura; Casa de Rui Barbosa, 1960.

Obra crítica. Vol. III (1895-1900). Rio de Janeiro: MEC; Casa de Rui Barbosa, 1963.

Obra crítica. Vol. II (1888-1894). Rio de Janeiro: MEC; Casa de Rui Barbosa, 1960.

Araripe Júnior: teoria, crítica e história literária. Seleção e apresentação de Alfredo Bosi. São Paulo:Edusp, 1978.

ASSIS, Machado de. O ideal do crítico. Organização de Miguel Sanches Neto. Rio de Janeiro: José Olympio, 2008.

. Papéis avulsos. Rio de Janeiro: Livraria Garnier, 1989.

Contos completos de Machado de Assis. Organização de Djalma

Cavalcante. Juiz de Fora: UFJF, 2003.

Contos fluminenses. Edição preparada por Marta de Senna. São

Paulo: Martins Fontes, 2006.

Histórias sem data. Edição preparada por Marta de Senna. São

Paulo: Martins Fontes, 2005.

Histórias sem data. Rio de Janeiro: Livraria Garnier, 2003.

Memórias póstumas de Brás Cubas. São Paulo: Penguin

Classics/Companhia das Letras, 2014.

Papéis avulsos. Edição preparada por Ivan Teixeira. São Paulo:

Martins Fontes, 2005.

Ressurreição. 5. ed. São Paulo: Ática, 1977.

Várias histórias. Edição preparada por Hélio de Seixas Guimarães.

São Paulo: Martins Fontes, 2004.

AUERBACH, Erich. A novela no início do Renascimento: Itália e França. Trad. Tercio Redondo. São Paulo: Cosac Naify, 2013.

Mimesis: a representação da realidade na literatura ocidental.

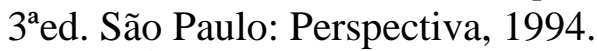

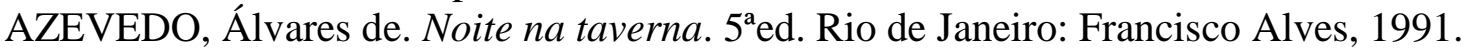

BANDEIRA, Manuel. Apresentação da poesia brasileira. São Paulo: Cosac Naify, 2009

BARTHES, Roland. "O efeito de real”. In.: O rumor da língua. Tradução de Mário Laranjeira. São Paulo: Martins Fontes, 2004.

BASTAZIN, Vera. "Do ato de contar ao metaconto: recorrências e transformações dos gêneros literários em Machado de Assis". In.: Recortes machadianos. Org. Ana Salles Mariano e Maria Rosa Duarte de Oliveira. São Paulo: EDUC, 2003, p.181210.

BENJAMIN, Walter. "O narrador. Considerações sobre a obra de Nikolai Leskov". In: Magia e técnica, arte e política: ensaios sobre literatura e história da cultura. Trad. de Sérgio Paulo Rouanet. $7^{\text {a }}$ ed. São Paulo: Brasiliense, 1994. 
BOECHAT, Maria Cecília. "Da ação folhetinesca à cena intimista: um conto romântico de Casimiro de Abreu". Teresa: revista de Literatura Brasileira [12|13]; São Paulo: Universidade de São Paulo, p. 271-286, 2013.

BOSI, Alfredo et alli. Machado de Assis: antologia e estudos. São Paulo: Ática, 1982. BOSI, Alfredo. "A máscara e a fenda”. In.: O enigma do olhar. São Paulo: Ática, 2000. BRAIT, Beth. Ironia em perspectiva polifônica. Campinas: Editora da Unicamp, 1996.

BRAYNER, Sonia. Labirinto do espaço romanesco: tradição e renovação da literatura brasileira, 1880-1920. Rio de Janeiro: Civilização Brasileira; Brasília: INL, 1979.

BROCA, Brito. "Um jornal literário-humorístico em 1881”. In: Naturalistas, parnasianos e decadistas: vida literária do Realismo ao Pré-Modernismo. Campinas: Editora da Unicamp, 1991, p.76-78.

CANDIDO, Antônio. Formação da literatura brasileira: momentos decisivos. Vol. 2. $6^{\mathrm{a}}$ ed. Belo Horizonte: Itatiaia, 2000.

Literatura e sociedade. $8^{\mathrm{a}}$ ed. São Paulo: T.A. Queiroz, 2000.

CARPEAUX, Otto Maria. “Acontecimento”. In: Livros na mesa. Rio de Janeiro: Livraria São José, 1960.

Janeiro: MEC, s.d. "Contos de Tchekhov". In: Perguntas e respostas. Rio de "Obras primas desconhecidas do conto brasileiro", A Manhã, "Letras e Artes", Rio de Janeiro, 10 abr. 1949. Folha da Manhã, Quarto caderno, São Paulo, 15 maio de 1949.

CAVALHEIRO, Edgard. Evolução do conto brasileiro. Rio de Janeiro: MEC, 1954.

CORTÁZAR, Julio. "Alguns aspectos do conto". In.: Valise de cronópio. São Paulo: Perspectiva, 1993.

COSTA, Emília Viotti da. "Patriarcalismo e patronagem: mitos sobre a mulher no século XIX”, último capítulo de Da Monarquia à República: momentos decisivos. $9^{\mathrm{a}} \mathrm{ed}$. São Paulo: Editora UNESP, 2010

CRESTANI, Jaison Luís. "A colaboração de Machado de Assis no Jornal das Famílias: subordinações e subversões”. Patrimônio e Memória. Unesp/FCLAs/CEDAP, v.2, n.1, 2006.

Curso de conto. Rio de Janeiro: Academia Brasileira de Letras, 1958.

DIXON, Paul. "Modelos em movimento: os contos de Machado de Assis". In: Teresa. Revista de Literatura Brasileira, 6/7. São Paulo: USP; Editora 34, 2006, p. 31-55.

Os contos de Machado de Assis: mais do que sonha a filosofia. Porto Alegre: Movimento, 1992.

EIKHENBAUM, Boris. "Sobre a teoria da prosa”. In: Teoria da literatura: formalistas russos. Organização de Dionísio de Oliveira Toledo. Porto Alegre: Globo, 1976.

EULÁLIO, Alexandre. "O último bom selvagem: 'Luís da Serra', de Lúcio de Mendonça". In.: Tempo reencontrado: ensaios sobre arte e literatura. Organização e apresentação Carlos Augusto Calil. São Paulo: IMS/Editora 34, 2012.

FREIRE, Gilberto. O escravo nos anúncios de jornais brasileiros do século XIX. $4^{\mathrm{a} e d .}$ São Paulo: Global, 2010.

FRIEDMAN, Norman. "O ponto de vista na ficção: o desenvolvimento de um conceito crítico. Revista USP, São Paulo, no 53, p. 166-182, março/maio 2002. . "O que faz um conto ser curto?". Trad. Marta Cavalcante de Barrros. Revista USP, São Paulo, n.63, p.219-230, setembro/novembro 2004.

FRYE, Northrop. Anatomia da crítica: quatro ensaios. Trad. de Marcos de Martini. São Paulo: É Realizações, 2013. 
GLEDSON, John. "A parasita azul": ficção, nacionalismo e paródia. Cadernos de Literatura Brasileira, números 23 e 24, Julho de 2008. São Paulo: Instituto Moreira Salles.

• "Introdução". In.: Machado de Assis: crônicas escolhidas. Seleção, Letras, 2013.

."Machado de Assis e a crise dos quarenta anos". Machado Assis em linha, Rio de Janeiro. v. 4, n. 8, p. 10-31, dezembro 2011.

GODIN, Eunice. Vida e obra de Paula Brito "Iniciador do movimento editorial no Rio de Janeiro” (1809-1861). Rio de Janeiro: Livraria Brasiliana Editora, 1965.

GOMES, Eugênio. "Evolução do conto". In: COUTINHO, Afrânio (org.). A literatura no Brasil. Vol. VI. Rio de Janeiro: Editorial Sul Americana, 1955.

"Raul Pompeia, contista". In.: POMPEIA, Raul. Contos. Obras, vol.3, org. de Afrânio Coutinho. Rio de Janeiro, Civilização Brasileira/OLAC, 1981.

1958.

GRIECO, Agrippino. Evolução da prosa brasileira. Rio de Janeiro: Ariel, 1933.

GUIMARÃES JR., Luís. A família Agulha: romance humorístico. Organização, edição e notas de Flora Sussekind. $3^{\mathrm{a}}$ ed. Rio de Janeiro: Vieira \& Lent: Fundação casa de Rui Barbosa, 2003.

HANSEN, João Adolfo. "O imortal" e a verossimilhança. In.: Teresa, revista de Literatura Brasileira [6/7]; São Paulo, 2006, p.56-78.

HAUSER, Arnold. História social da literatura e da arte. Trad. de Walter H. Geenen. Vol. II. São Paulo: Mestre Jou, 1982.

HEAD, Dominic. The modernist short story: a study in theory and practice. Cambridge: Cambridge University Press, 1994.

HEINEBERG, Ilana. "Figurações do autor e narração excêntrica em Nodier e Guimarães Júnior". In.: Navegações, v.1, n.1, p.41-49, março de 2008. revistaseletronicas.pucrs.br/ojs/índex.php/navegações/article/viewFile/3683/2833 Acessado em 14/09/2016.

JOLLES, Andrés. Formas simples. Trad. Álvaro Cabral. São Paulo: Cultrix, 1976.

LIMA, Alceu Amoroso. "A evolução do conto no Brasil". In.: Curso de conto. Rio de Janeiro: Academia Brasileira de Letras, 1958, p.17.

LIMA, Herman. "O conto, do realismo aos nosso dias". In: A literatura no Brasil. Vol.II. Organização de Afrânio Coutinho. Rio de Janeiro: Editorial Sul Americana, 1955. - Variações sobre o conto. Rio de Janeiro: Ministério da Educação e Saúde, 1952. Coleção Cadernos de Cultura, número 37.

LINHARES, Temístocles. 22 diálogos sobre o conto brasileiro atual. Rio de Janeiro: Olympia, 1973.

"Naturalismo psicológico e Impressionismo". In: História crítica do romance brasileiro. Vol. 1. São Paulo: Edusp; Itatiaia, 1987.

Lúcio de Mendonça: o homem e a obra. Organização de Eliana de Mendonça Penafiel e Orlando Meirelles Padilha. Rio de Janeiro: O. Meirelles Padilha, 2004.

MACHADO, Ubiratan (org.). Machado de Assis - roteiro de consagração. Rio de Janeiro, Ed. UERJ, 2003.

MARQUES, Ivan “A ciência corroída". In: Histórias do Realismo. Organização de Ivan Marques. São Paulo, Scipione, 2006.

MARTINS, Wilson. "Clássicos do humorismo". In.: O Globo Online, 21/02/2004. www.jornaldepoesia.jor.br/wilsonmartins126.html Acessado em 10/09/2016 
MASSA, Jean-Michel. Dispersos de Machado de Assis. Rio de Janeiro: MEC/INL, 1965

MENDONÇA, Edgar e Carlos Sussekind de. Lúcio de Mendonça: ensaio biobibliográfico. Rio de Janeiro: Civilização Brasileira, 1934.

MENDONÇA, Lúcio de. Esboços e perfis; Horas do bom tempo: memórias e fantasias. Apresentação de Carlos Sussekind de Mendonça Filho. Rio de Janeiro: Academia Brasileira de Letras, 2003.

MORETTI, Franco. O burguês: entre a história e a literatura. Trad. Alexandre Morales. São Paulo: Três Estrelas, 2014.

NEAL, Dyana. "The Bohemian life according to Henri Murger (1822-1861)". http://www.wbjc.com/the-bohemian-life/ . Também em http://www.universalis.fr/encyclopedie/henri-murger/

NEVES, Ângela das. Contistas à Maupassant: a recepção criativa de Guy de Maupassant no Brasil. Tese de doutoramento. São Paulo: FFLCH/USP, 2012.

OLIVEIRA, Aline Sobreira de. A medalha e seu reverso: fantástico e desfantasticização em contos de Machado de Assis. Dissertação de mestrado. Belo Horizonte: UFMG, 2012.

PASSOS, Cleusa Rios P. "Breves considerações sobre o conto moderno". In: Ficções: leitores e leituras. Cotia: Ateliê, 2001, p. 67-90.

PASSOS, José Luiz. Machado de Assis: o romance com pessoas. São Paulo: Edusp/Nankin, 2007.

PEREIRA, Lúcia Miguel. Machado de Assis: estudo crítico e biográfico. 6.ed. Belo Horizonte: Itatiaia; São Paulo: Editora da Universidade de São Paulo, 1988.

. Prosa de ficção: 1870 a 1920. Rio de Janeiro: José Olympio, 1962.

PIGLIA, Ricardo. "Teses sobre o conto". In: Formas breves. Trad. José Marcos Mariani de Macedo. São Paulo: Companhia das Letras, 2004.

POMPÉIA, Raul. Contos. Obras, vol. III. Organização e notas de Afrânio Coutinho. Rio de Janeiro: Civilização Brasileira; Oficina Literária Afrânio Coutinho; FENAME, 1981.

- Miscelânea/Fotobiografia. Obras, vol. X. Organização e notas de Afrânio Coutinho. Rio de Janeiro: Prefeitura Municipal de Angra dos Reis; Oficina Literária Afrânio Coutinho, 1991.

PONTIERI, Regina. "Formas históricas do conto: Poe e Tchékhov". In: Ficções: leitores e leituras. Organização de Viviana Bosi et alli. Cotia: Ateliê, 2001, p.91-111.

PORTO, Jakeline Longo. Francisco de Paula Brito: um precursor da narrativa brasileira no século XIX. Dissertação de Mestrado. São José do Rio Preto: UNESP, 2017.

RAMOS, Ana Flávia Cernic. "Imprensa e literatura: o caso Castro Malta na configuração do jornalismo carioca em finais do século XIX”. VI Simpósio Nacional de História Cultural: Escritas da História: Ver - Sentir - Narrar. Teresina: Universidade Federal do Piauí, s.d.

RAMOS, Graciliano. Conversas. Org. Ieda Lebensztayn e Thiago Mio Salla. Rio de Janeiro: Record, 2014.

Seleção de contos brasileiros. Vol.2. Rio de Janeiro: Edições de Ouro, 1966.

RAMOS, Maria Luiza. Psicologia e estética de Raul Pompéia. Belo Horizonte, [1957?]. Tese (Cátedra de Literatura Brasileira) - Faculdade de Filosofia, Universidade Federal de Minas Gerais.

RANCIÈRE, Jacques. O fio perdido: ensaios sobre a ficção moderna. Trad. Marcelo Mori. São Paulo: Martins Fontes, 2017. 
REIMAR, Flavio. Pseudônimo de Gentil Homem de Almeida Braga. Entre o céu e a terra. São Luís: Tipografia de B. de Mattos, 1869.

RIBEIRO, José Alcides. "Raul Pompéia e a ficção nos jornais: ironia, humor e visualidade". Revista USP, São Paulo, nº72, p.129-142, dez-fev, 2006/2007.

SANTOS, Sidnei Xavier dos. As metamorfoses de Raul Pompeia: um estudo dos contos. Dissertação de mestrado. São Paulo: Universidade de São Paulo, 2011

"O conto esquecido pelo Modernismo: Tílburi de praça, de Raul Pompeia". Anais do X SEL Seminário de Estudos Literários "Cultura e Representação”, Assis, p.1-10, 2010. Disponível em http://sgcd.assis.unesp.br/Home/PosGraduacao/Letras/SEL/anais_2010/sidneixavi er.pdf

SCHIMIDT, Afonso. O Canudo: Raul Pompeia em São Paulo. São Paulo: Clube do Livro, 1963.

SCHWARZ, Roberto. "A novidade das Memórias póstumas de Brás Cubas". In.: Machado de Assis: uma revisão. Org. de Antônio Carlos Secchin, José Maurício Gomes de Almeida e Ronaldes de Melo e Souza. Rio de Janeiro: In-Fólio, 1998. "A viravolta machadiana". Novos estudos, CEBRAP, n.69, julho de 2004, p.15-34.

"As idéias fora do lugar". In: Ao vencedor as batatas: forma literária e processo social nos inícios do romance brasileiro. $4^{\mathrm{a}}$ ed. São Paulo: Duas Cidades, 1992.

SILVA, Marciano Lopes e. O mal de D. Quixote: Romantismo e filosofia da História na obra de Raul Pompéia. São Paulo: Ed. Unesp, 2008.

SILVA, Marcos Fabrício Lopes da. "Gênero e etnicidade nos contos de Francisco de Paula Brito: entre a submissão e o destemor". In.: Terra Roxa e outras terras, vol.17-B, dezembro 2009, p.125-134.

SOBRINHO, Barbosa Lima (org.). Os precursores do conto no Brasil. Rio de Janeiro: Civilização Brasileira, 1960, col. Panorama do conto brasileiro, v.1.

SODRÉ, Nelson Werneck. História da literatura brasileira: seus fundamentos econômicos. $4^{\mathrm{a}}$ ed. Rio de Janeiro: Civilização Brasileira, 1964.

SOUZA, J. Galante de. Bibliografia de Machado de Assis. MEC, Instituto Nacional do Livro, Rio de Janeiro, 1955.

TODOROV, Tzvetan. "Os dois princípios da narrativa”. In: Os gêneros do discurso. São Paulo: Martins Fontes, 1980, p.61-74.

Fontes, 2003.

Poética da prosa. Trad. Cláudia Berliner. São Paulo: Martins

TYNIANOV, J. "Da evolução literária". In: Teoria da literatura: formalistas russos. Organização de Dionísio de Oliveira Toledo. Porto Alegre: Globo, 1976.

VASCONCELOS, Sandra Guardini T. "Romances ingleses em circulação no Brasil durante $\quad 0$ século XIX”. In.: www.unicamp.br/iel/memoria/Ensaios/Sandra/sandralev.htm . Acessado em $\underline{12 / 09 / 16}$

VIANNA, Glória. "Revendo a biblioteca de Machado de Assis". In.: JOBIM, José Luís (Org.). A biblioteca de Machado de Assis. Rio de Janeiro: Topbooks, 2001.

Vida cotidiana em São Paulo no século XIX: memórias, depoimentos, evocações. Org. de Carlos Eugênio Marcondes de Moura. São Paulo: Ateliê, 1999.

VOLOBUEF, Karin. Frestas e arestas: a prosa de ficção do Romantismo na Alemanha e no Brasil. São Paulo: UNESP, 1999.

WOOD, James. Como funciona a ficção. Trad. Denise Bottmann. São Paulo: Cosac Naify, 2012. 
